\title{
10. ONTONG JAVA PLATEAU, LEG 130: SYNOPSIS OF MAJOR DRILLING RESULTS ${ }^{1}$
}

\author{
W. H. Berger, ${ }^{2}$ L. W. Kroenke, ${ }^{3}$ L. A. Mayer, ${ }^{4}$ and Shipboard Scientific Party ${ }^{5}$
}

\begin{abstract}
Sixteen holes were drilled at five sites on the northeastern flank of Ontong Java Plateau during Leg 130 (Sites 803 through 807$)$. All of these sites are near the equator, but are at different depths $\left(803: 02^{\circ} 26.0^{\prime} \mathrm{N}, 3410 \mathrm{~m} ; 804\right.$ $01^{\circ} 00.3^{\prime} \mathrm{N}, 3861 \mathrm{~m} ; 805: 01^{\circ} 13.7^{\prime} \mathrm{N}, 3188 \mathrm{~m} ; 806: 00^{\circ} 19.1^{\prime} \mathrm{N}, 2520 \mathrm{~m}$; and 807: $\left.03^{\circ} 36.4^{\prime} \mathrm{N}, 2805 \mathrm{~m}\right)$. One of our goals was to obtain a depth transect of Neogene carbonate deposition for reconstructing the history of ocean climate, chemistry, and productivity, and for understanding the origin of acoustic reflectors. Another goal was to achieve considerable penetration into basement for elucidating the origin of the plateau.

All sites yielded multiple Neogene sequences, which were cored using the advanced hydraulic piston corer (APC) to the ooze-chalk transition (10-14 Ma) and with the extended core barrel (XCB) below that. Sites 803 and 807 were drilled to basement and yielded incomplete Paleogene and Cretaceous sections. Penetration into basement was $25 \mathrm{~m}$ at Site 803 and $149 \mathrm{~m}$ at Site $807 ; 98 \mathrm{~m}$ of basalt was recovered. In all, we cored $5889 \mathrm{~m}$, taking 639 cores. Of the record $4822 \mathrm{~m}$ recovered, $55 \%$ was taken with the APC, $39 \%$ with the $\mathrm{XCB}$, and $6 \%$ with the rotary core barrel (RCB). All sites except Site 804 were logged.

Neogene sedimentation rates were found to vary by more than a factor of 2 , with a striking maximum in the latest Miocene to early Pliocene and a strong minimum in the Pleistocene. Fluctuations in carbonate content on the millionyear scale are highly coherent among depths over the last 12 m.y., perhaps less so before that. Many acoustic reflectors appear synchronous with carbonate reduction events (CREs) and other paleoceanographic events. Other reflectors are tied to diagenesis (e.g., the ooze-chalk transformation, which is diachronous).

Recovery of the Cretaceous/Tertiary (K/T) boundary at Sites 803 and 807 demonstrates the presence of a deep carbonate-compensation depth $(\mathrm{CCD})$ across the transition: one sequence is calcareous, the other is not. Because the $\mathrm{K} / \mathrm{T}$ sections occur below and above major hiatuses, we postulate that special conditions for preservation existed during the transition. In addition, there is evidence of volcanic activity at that time.

The basalts cored at Sites 803 and 807 are predominantly olivine-bearing and were erupted during the mid-Cretaceous. At Site 807, pillow lavas buried sediments. One thick flow (at about $28 \mathrm{~m}$ ) was penetrated here, apparently a flood basalt. Magnetic paleolatitudes suggest that the Ontong Java Plateau has moved coherently with the Pacific Plate since the Early Cretaceous.
\end{abstract}

\section{INTRODUCTION}

The five sites drilled during Ocean Drilling Program (ODP) Leg 130 are situated on the northeastern flank of the Ontong Java Plateau in the western equatorial Pacific, a region well known for its excellent pelagic record (Fig. 1). This record was explored during three previous Deep Sea Drilling Project (DSDP) expeditions that provided information on Sites 64, 288, 289, and 586 to the south of the Leg 130 area (Shipboard Scientific Party, 1971, 1975a, 1975b, 1986).

The unique geological setting of the plateau, a region long elevated above the surrounding seafloor because of its anomalously thick crust (Hussong et al., 1979), led to the accumulation and preservation of a thick cover of calcareous sediments. Situated well away from special boundary conditions, a pelagic record has collected on the plateau that is eminently suited for high-resolution studies of global ocean signals. In addition, there are indications that paleoceanographic events can be traced in the physical properties of sediments, providing a link to the seismic record that allows both three-dimensional regional mapping and long-distance correlation. Last, but not least, the tectonic

\footnotetext{
${ }^{1}$ Kroenke, L. W., Berger, W. H., Janecek, T. R., et al., 1991. Proc. ODP, Init. Repts., 130: College Station, TX (Ocean Drilling Program).

2 Research Associate, University of Bremen, D2800 Bremen, Federal Republic of Germany (permanent address: Scripps Institution of Oceanography, La Jolla, CA 92093, U.S.A.)

${ }^{3}$ Hawaii Institute of Geophysics, Honolulu, HI 96822, U.S.A.

4 Dalhousie University, Halifax, Nova Scotia, B3H-4JI, Canada.

5 Shipboard Scientific Party is as given in the list of participants preceding the contents.
}

history of the Ontong Java Plateau, the largest plateau in the Pacific, has been studied frequently (see Kroenke, 1972, 1984). The plateau is of subcontinental size (e.g., it is much larger than the Iberian peninsula), and its origin is of considerable interest in the context of large-scale tectonics.

Leg 130 scientists had two major goals that differed from those of previous cruises: (1) the cruise was designed to furnish a depth transect for the Neogene portion of the sediment cover, and (2) it was planned to penetrate deeply into basement. Both these goals were fully met. In addition, our intent was to recover as much of the Paleogene and Cretaceous record as time would permit, given the priorities mentioned, with the aim of obtaining the means for detailed reconstruction of paleoceanography and paleoclimate for these earlier periods as well. Leg 130 also succeeded in this aim when all sites penetrated into pre-Neogene sediments and samples from throughout the Paleogene and Cretaceous were recovered from two sites. In addition, complete (or nearly complete) records (one calcareous, the other noncalcareous) of the Cretaceous/Tertiary $(\mathrm{K} / \mathrm{T})$ boundary were recovered from Sites 803 and 807 .

\section{DRILLING STRATEGY AND MAIN RESULTS}

\section{Objectives}

As mentioned, a major goal of Leg 130 was to sample sedimentary sequences at different depths along the equator for a Neogene depth transect (Figs. 2 and 3). This transect was planned so as to procure the material for high-resolution stratigraphic studies of paleoceanographic changes (water temperature, productivity, carbonate chemistry) (1) for assessing the equatorial dynamics of the western Pacific, (2) for comparing results with 


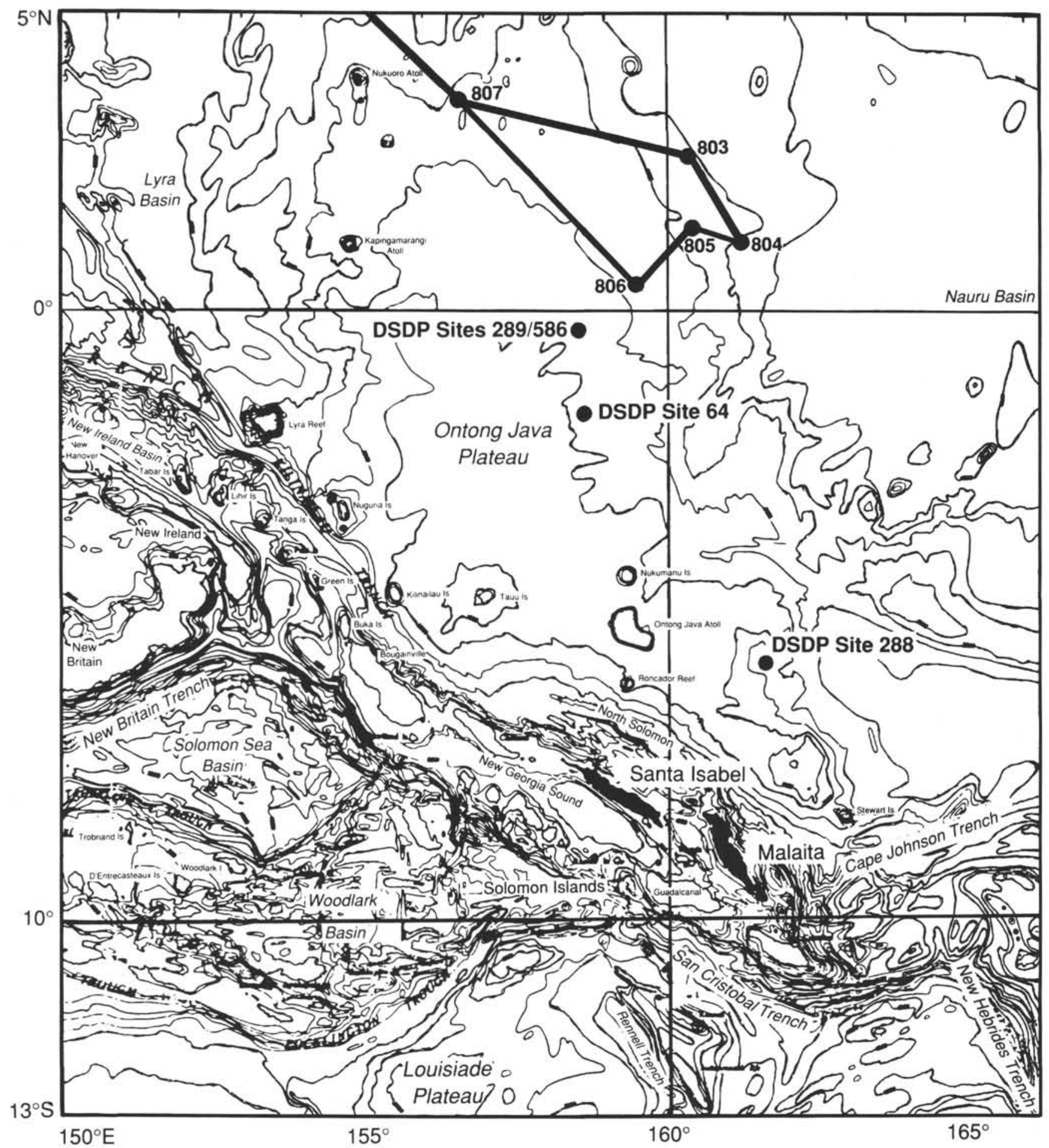

Figure 1. Geographic setting of Leg 130 sites, and relationship to DSDP Sites 64 (Leg 7), 288 and 289 (Leg 30), and 586 (Leg 89 ). Bathymetry from Kroenke et al. (1983). Contour interval is $500 \mathrm{~m}$.

other equatorial depth transects, and (3) for clarifying the origin and significance of the ubiquitous subparallel reflectors in pelagic carbonates here and elsewhere, with the hope that an understanding of the origin of these reflectors would provide a valuable paleoceanographic tool.

Four ODP sites $(803,804,805$, and 806$)$ address this. Including DSDP Sites $289 / 586$, then, there are five equatorial sites that span a depth interval of almost $2000 \mathrm{~m}$. The sediments thus sampled essentially were produced in the same surface-water conditions and have been derived from the same pelagic rain. The depth interval bracketed by our sites (2500-3900 m) contains the depth range in which changes in dissolution gradients are most pronounced, with considerable effects on physical properties and, hence, seismic properties (Berger and Johnson, 1976; Johnson et al., 1977; Berger and Mayer, 1978; Mayer et al., 1985, 1986). 


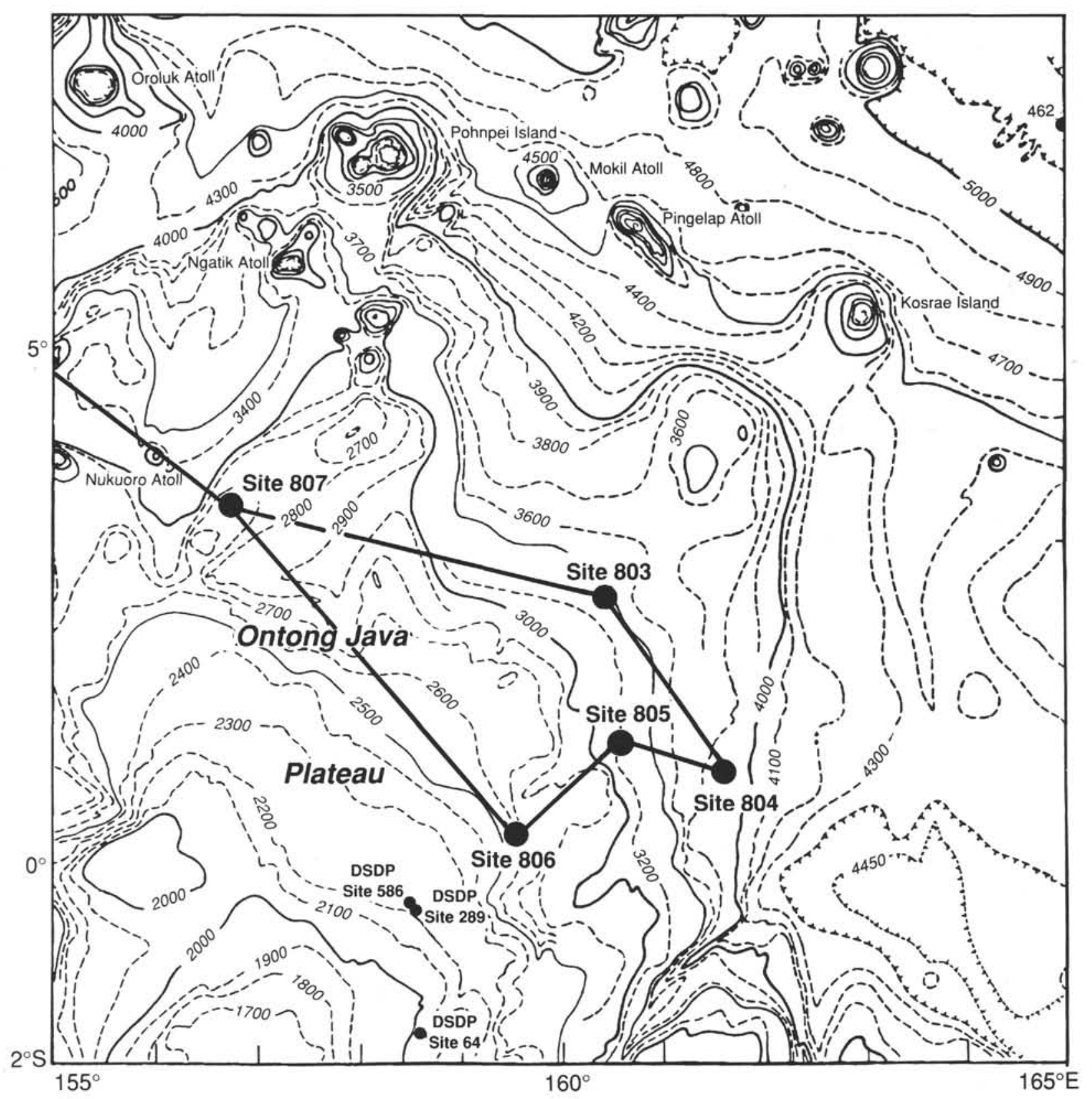

Figure 2. Location of Sites 803-807. Proximity to equator and a spread of depths in an undisturbed section were the criteria of selection. Bathymetry after Mammerickx and Smith (1985). Contour interval is $100 \mathrm{~m}$.

The Cretaceous-Paleogene section was another of our objectives because of the intrinsic interest of ocean conditions outside of the range of those of the more familiar Neogene and also because this record provides a reference for Southern Hemisphere paleoceanography and bears on the early history of the plateau itself. Major hiatuses previously were encountered in that section, which made it unlikely that we would find complete sequences. Yet, scientists thought that many of these hiatuses are of local extent, so that additional drilling might be expected to fill at least some of the gaps.

Drilling into basement was a high priority. The origin of the old oceanic Pacific plateaus (Ontong Java, Manihiki, Shatsky, Hess, Magellan) is a problem with many implications for mantle processes and the evolution of the seafloor. The relationship of the plateau basalts to the extensive "mid-Cretaceous" vol- canic events of the Pacific is of special interest. There also are implications for climatic change $\left(\mathrm{CO}_{2}\right.$ influx, hydrothermal activity) and possibly for the origin of continental crust in general (Kroenke, 1974).

\section{Drilling Statistics}

The JOIDES Resolution sailed from Guam on 23 January 1990 and returned to Guam on 27 March 1990, after 62.7 days at sea. Of these, 51.2 days were spent on site; the rest was spent while the ship was under way, including seismic profiling and site positioning. A total of 16 holes were drilled at five sites (Table 1).

All sites yielded multiple Neogene sequences using the advanced hydraulic piston corer (APC) to refusal (near the oozechalk transition), and the extended core barrel (XCB) below 


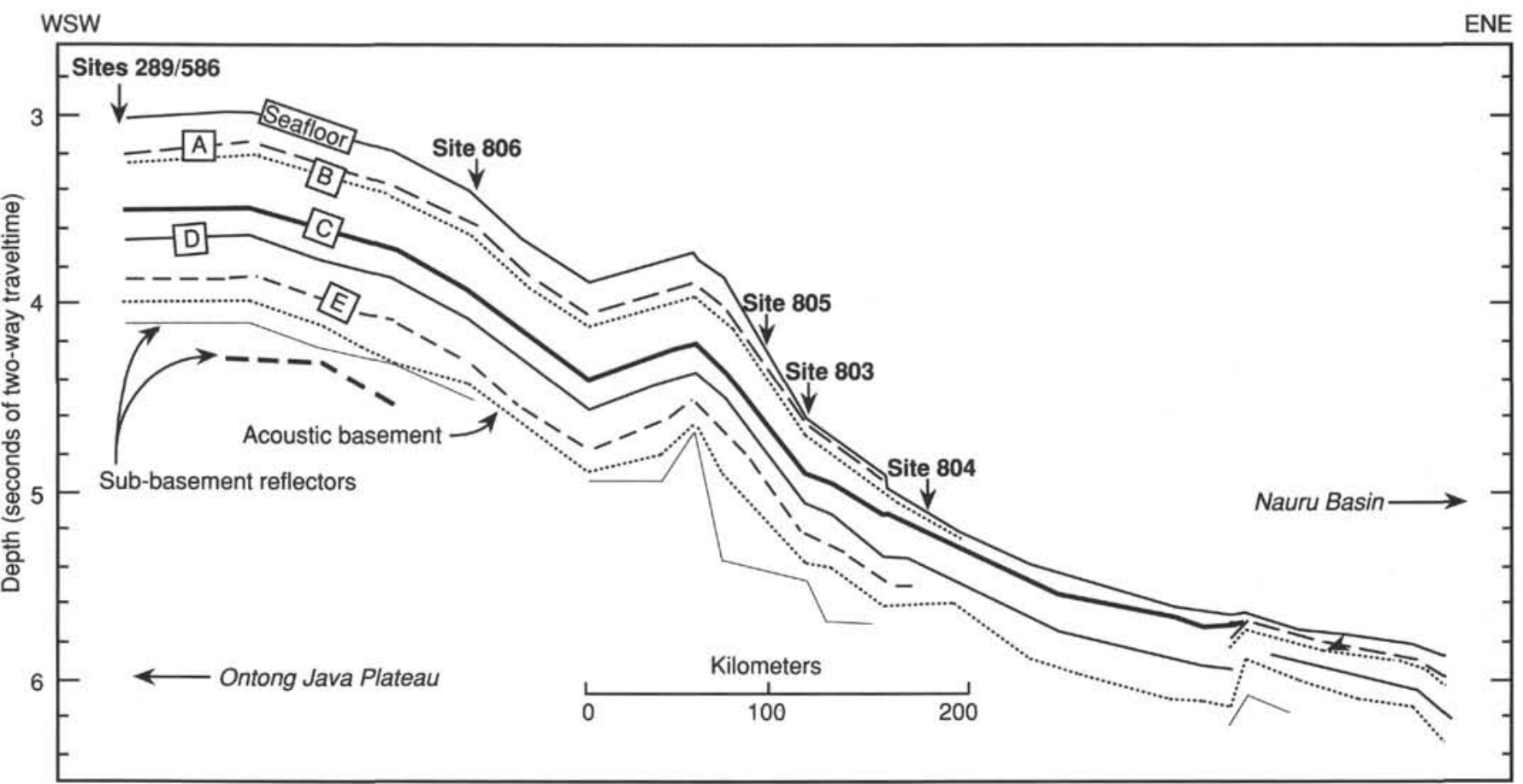

Figure 3. Simplified acoustic stratigraphy for the flank of the Ontong Java Plateau, and approximate locations of Sites 803-806 (the Neogene depth transect).

Table 1. Leg 130 site locations and drilling statistics.

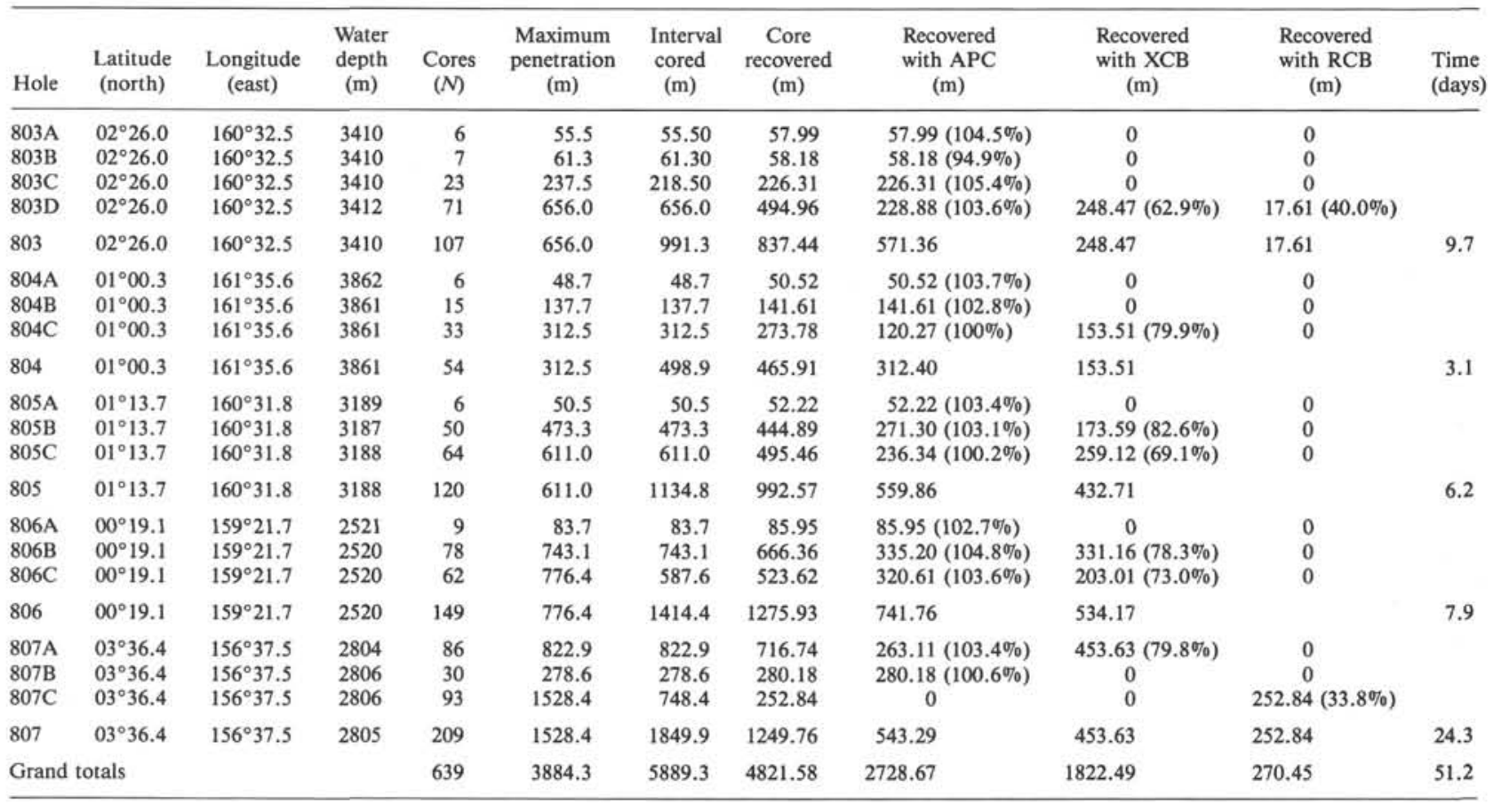

that. Sites 803 and 807 were deepened by rotary core barrel (RCB) drilling, reaching basement and yielding Paleogene and Cretaceous sections (Fig. 4). Penetration into basement was $25 \mathrm{~m}$ at Site 803 and $149 \mathrm{~m}$ at Site $807 ; 98 \mathrm{~m}$ of basalt was recovered. In all, we cored $5889 \mathrm{~m}$, taking 639 cores. Of the record $4822 \mathrm{~m}$ recovered, $56.5 \%$ was by taken with the APC, $38 \%$ with the $\mathrm{XCB}$, and $5.5 \%$ with the $\mathrm{RCB}$. Four sites were logged extensively.

\section{Main Results}

\section{Site 803}

Four holes were drilled at Site $803\left(2^{\circ} 26.0^{\prime} \mathrm{N}, 160^{\circ} 32.5^{\prime} \mathrm{E}\right.$; water depth, $3410 \mathrm{~m}$ ), the last of which (803D) was drilled into basement and terminated at $656.0 \mathrm{~m}$ below seafloor (mbsf) (see Table 1 for drilling and recovery statistics). The acoustic thickness of the sediment is about $0.64 \mathrm{~s}$ (two-way traveltime [TWT]; 


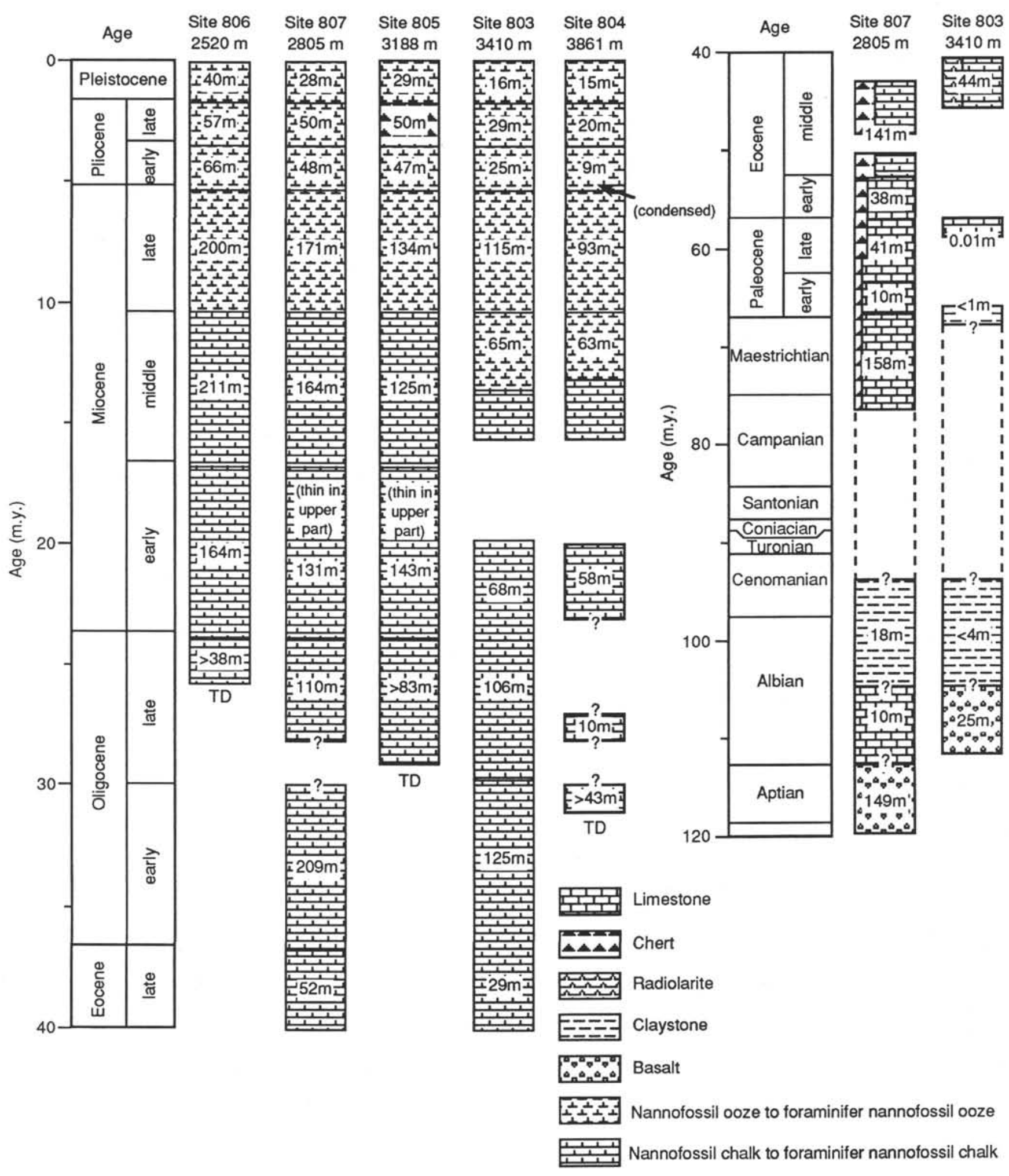

Figure 4. Sites drilled on Ontong Java Plateau during Leg 130. Sites are arranged according to depth: note decrease in thickness of correlative intervals, from left to right, and hiatus formation at the two deep sites. Sediment thicknesses listed are approximate values based on shipboard biostratigraphy. Age control through much of the Cretaceous is poor because of the poor preservation of calcareous microfossils. 
Fig. 5). The site was drilled near a strong "mid-section reverberation" (MSR), the origin of which is unknown. Reflectors were numbered from the top down at this site to identify them uniquely for subsequent correlation with other sites.

The recovered sediments range in age from Pleistocene to early Late Cretaceous; they were divided into three units. The uppermost Unit I takes up most of the section (0-563.7 mbsf); it ranges from upper Eocene to Pleistocene and consists of nannofossil ooze and chalk to foraminifer nannofossil ooze and chalk. The ooze-chalk transition occurs between 210 and 220 mbsf and provides the basis for dividing the unit into Subunits IA and IB. The logging data suggest that this transition ranges through $60 \mathrm{~m}$ or more in the sedimentary column. The foraminifer content is high in the Pleistocene and adjacent upper Pliocene ooze and decreases downhole through the first $30-60 \mathrm{mbsf}$, where it remains low throughout the rest of the section. The oozes and chalks of Unit I are uniform, although depositional cycles are evident in places where redox fluctuations are expressed as Liesegang color banding, which is thought to result from changing concentrations and states of oxidation of iron and manganese (Fig. 6).

Unit II (563.7-621.8 mbsf) ranges from middle to upper Eocene and consists of approximately $58 \mathrm{~m}$ of nannofossil chalk with radiolarians, radiolarian nannofossil chalk, nannofossil ra-

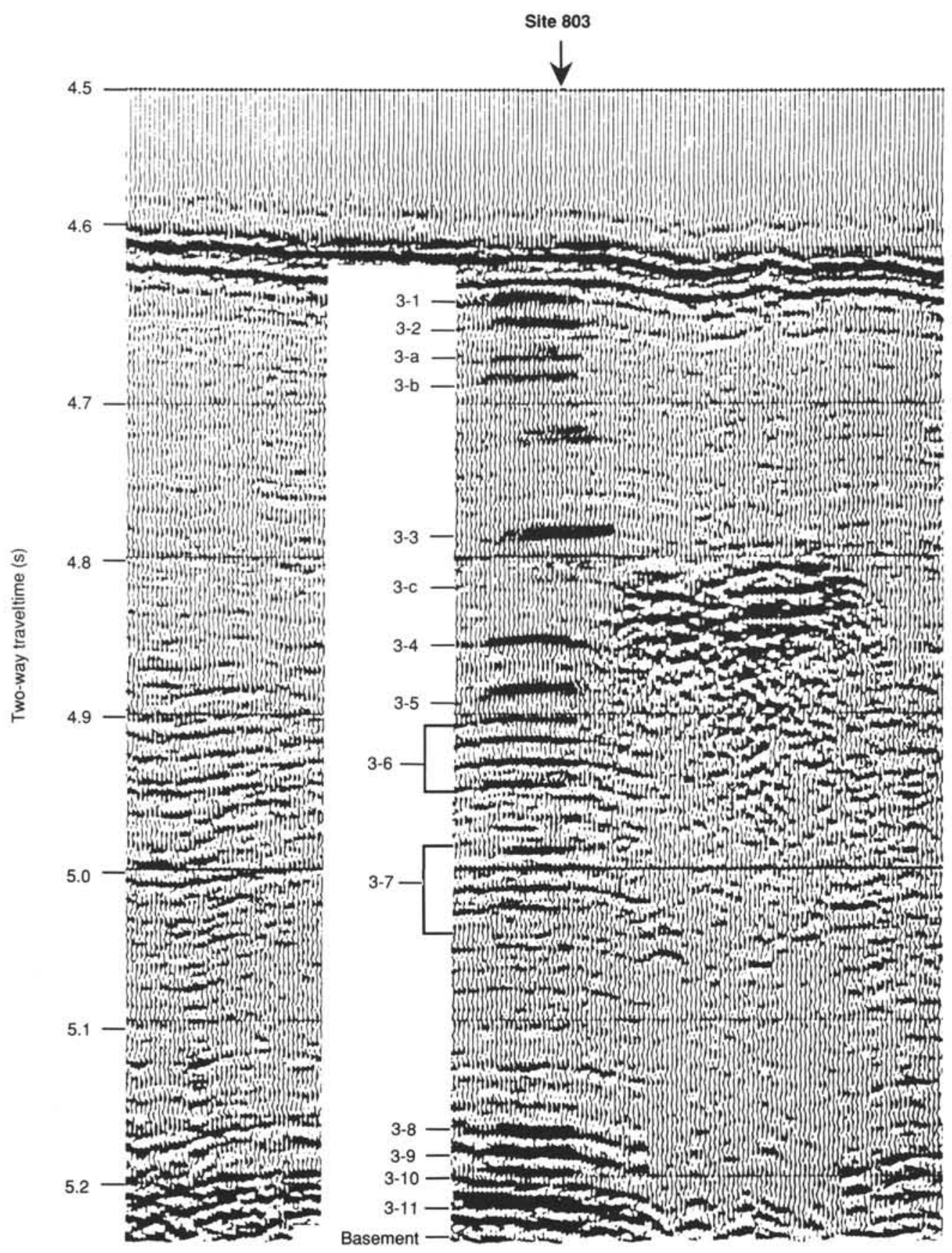

Figure 5. Seismic record at Site 803, collected by scientists on board the Thomas Washington during the ROUNDABOUT Cruise 11 site survey, using the 80 -in. ${ }^{3}$ water gun, $70-250 \mathrm{~Hz}$ band-pass filter. Numbers refer to reflectors and reflector groups. 


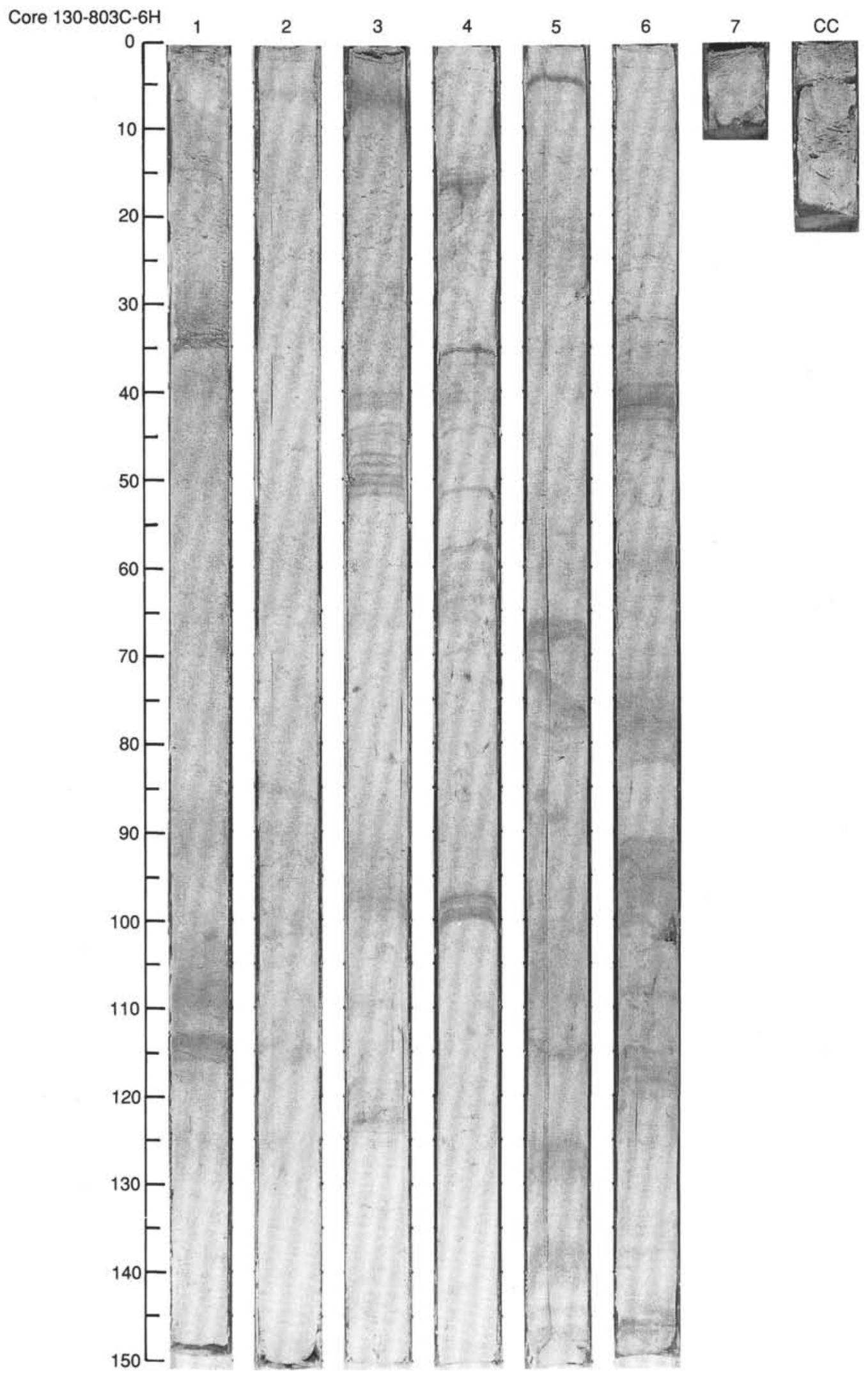

Figure 6. Liesegang color banding from Core 130-803C-6H (66.0-76.0 mbsf) in Subunit IA, nannofossil ooze. Bands are reddish gray, greenish gray, and pale green, and are believed to be caused by changes in concentrations and oxidation states in iron and manganese. 
diolarite, and minor amounts of chert. Unit III (621.8-626.3 mbsf) ranges from lower Upper Cretaceous to middle Eocene and is composed of claystone and clayey siltstone, with minor radiolarian-rich intervals. Resistivity logs suggest that this lithology continues from $621.8 \mathrm{mbsf}$ to basement at $630.4 \mathrm{mbsf}$. The K/T boundary was crossed at $622.25 \mathrm{mbsf}$, where an apparently complete boundary sequence was recovered.

The record is continuous from the Pleistocene to the lower Miocene section, where a significant stratigraphic break appears at 245.9 mbsf (about $15-20 \mathrm{Ma}$ ), the first of three major stratigraphic breaks encountered above the $\mathrm{K} / \mathrm{T}$ boundary. The other two breaks occur across the Paleocene/Eocene boundary ( $~ 45-$ $\sim 58 \mathrm{Ma})$ at $621.8 \mathrm{mbsf}$ and in the Paleocene $(\sim 58-\sim 66 \mathrm{Ma})$ immediately below. The section below the $\mathrm{K} / \mathrm{T}$ boundary, which was penetrated at $622.25 \mathrm{mbsf}$, is condensed and presumably also contains several substantial hiatuses.

Nine basalt subunits were recognized within basement rocks (Unit IV) on the basis of intercalated limestones or breccias. Their age is Cenomanian-upper Albian or older. These basalts are pillowed (Fig. 7) and are predominantly aphyric, finegrained, and nonvesicular tholeiites.

\section{Site 804}

Three holes were drilled at Site $804\left(1^{\circ} 00.3^{\prime} \mathrm{N}, 161^{\circ} 35.6^{\prime} \mathrm{E}\right.$; water depth, $3861 \mathrm{~m}$ ), with the deepest terminating at 312.5 mbsf in lower Oligocene nannofossil chalk (see Table 1 for drilling and recovery statistics). The seismic record (Fig. 8) shows an acoustic thickness of sediments of about $0.65 \mathrm{~s}$ TWT, similar to Site 803 . There is evidence for disturbance from mass movement.

The sediment retrieved is Neogene in age, except for the five deepest cores in Hole $804 \mathrm{C}$, in which Oligocene chalk was recovered (Cores 130-804C-29X to -33X). The entire column, from the oldest to the youngest deposits cored, was classified as nannofossil ooze and chalk and is considered as one lithologic unit. Major breaks are found in the upper Oligocene (hiatus at 270 mbsf, about 28-25 Ma) and at the lower-to-middle Miocene transition (hiatus at $197 \mathrm{mbsf}$, about $15-20 \mathrm{Ma}$ ). There is a condensed section or hiatus from the lower Pliocene section that occurred between 5 and $4 \mathrm{Ma}$ (46-43 mbsf) and one possibly within the middle Miocene, between 13 and 11 Ma (near 160 mbsf).

The ooze-chalk transition appears near 181 mbsf and serves as a boundary between the two subunits recognized within the nannofossil ooze and chalk. Here, the age is middle Miocene (about $13 \mathrm{Ma}$ ). Radiolarians are more common in the lower subunit, with a maximum in the lower Miocene section (near 200 mbsf), just below the lower/middle Miocene hiatus. Disturbance of layers (other than from coring) is evident in the section spanning the major hiatus from lower to middle Miocene (210-187 mbsf) and between 42 and 110 mbsf (most of the upper Miocene). This disturbance is especially prominent between 70 and 80 mbsf (7-8 Ma).

The site is characterized by mass movement, which limits its utility as a sublysoclinal standard section. Unfortunately, such movement is typical of this depth range (Berger and Johnson, 1976), so that undisturbed sediments will not be readily found. Seismic profiles exhibit incoherent crenulate reflections at several levels, as well as evidence for wedging along the margins of the basin or valley that contains the deposits. There is some indication that disturbance is associated preferentially with certain layers. This leads us to suspect that such layers may have been predisposed through conditioning during deposition to serve as slip planes when the opportunity arose (e.g., during earthquake activity).

\section{Site 805}

At Site $805\left(1^{\circ} 13.7^{\prime} \mathrm{N}, 160^{\circ} 31.8^{\prime} \mathrm{E}\right.$; water depth, $\left.3188 \mathrm{~m}\right)$, three holes were drilled, with the deepest reaching upper Oligo-

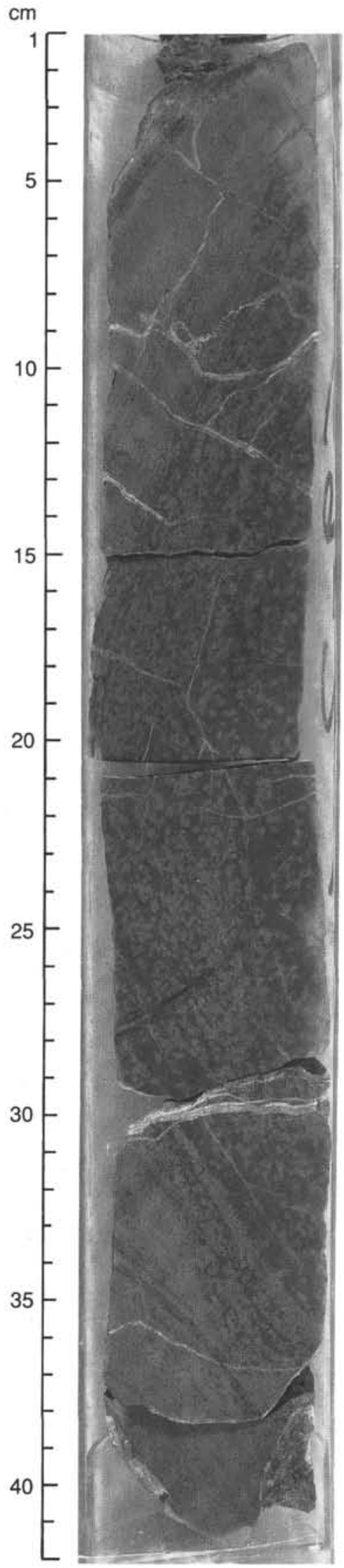

Figure 7. Basalt pillow penetrated by rotary drilling, at Site 803 (Interval 130-803D-69R-2, 1-42 cm). Note glassy rim (at top), fractures, vein fill, and signs of alteration of phenocrysts within fine-grained matrix. 


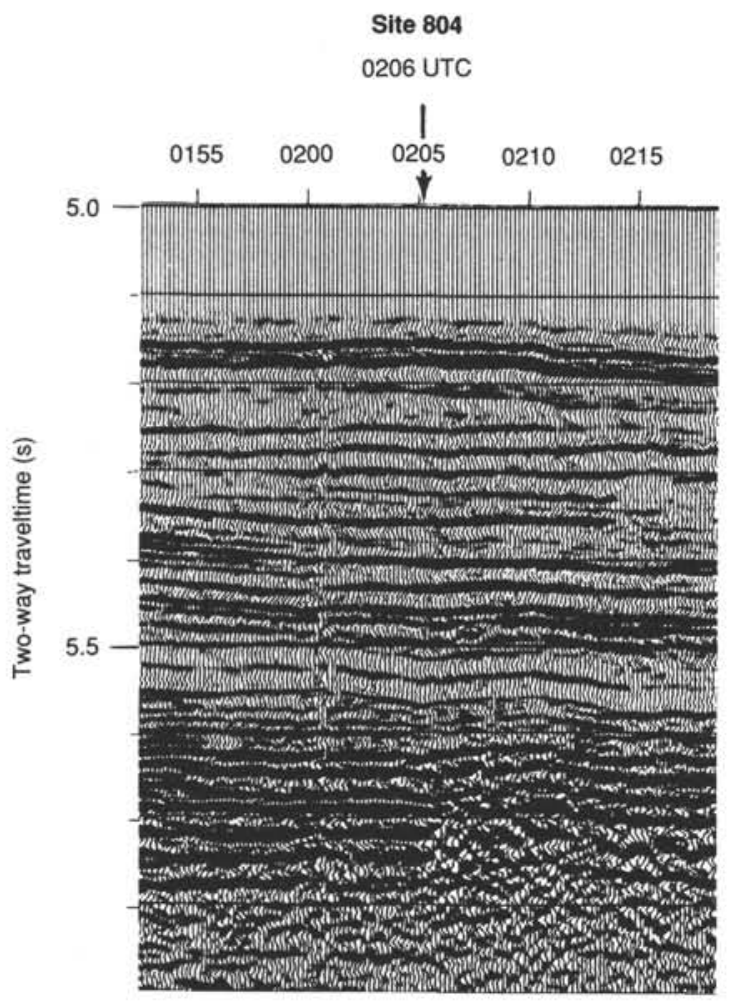

Figure 8 . Seismic record at Site 804 collected by the JOIDES Resolution before drilling, using the 80 -in. ${ }^{3}$ water gun, $25-250 \mathrm{~Hz}$ band-pass filter.

cene nannofossil chalk before total depth at 611 mbsf (see Table 1 for drilling and recovery statistics). The seismic record shows an acoustic sediment thickness of 0.85 to $0.90 \mathrm{~s}$ TWT (Fig. 9).

The retrieved sediment is Neogene in age, except for the eight deepest cores in Hole $805 \mathrm{C}$, where Oligocene chalk was recovered. The entire column, from the oldest deposits recovered to the seafloor, was considered as one lithologic unit and was classified as nannofossil and foraminifer nannofossil ooze and chalk. The average sedimentation rate for the unit was estimated as $21.5 \mathrm{~m} / \mathrm{m}$.y. No stratigraphic breaks were detected. However, sedimentation rates decrease to low values (below $10 \mathrm{~m} / \mathrm{m} . \mathrm{y}$.) near 10 and $18 \mathrm{Ma}$.

Two subunits were recognized on the basis of induration in this remarkably uniform section. These are separated by the ooze-chalk transition near $288 \mathrm{~m}( \pm 6 \mathrm{~m})$. The age of the transition is late middle Miocene (about $11.4 \mathrm{Ma}$ ). The transition is gradational and has alternating layers, with varying degrees of lithification. Recovery is incomplete in the chalk sections because of the grinding of chalk on chalk during coring (Fig. $10 \mathrm{~A})$. Fine-scale color banding is common in places and is thought to be related to Liesegang banding (Fig. 10B), that is, diffusion across redox gradients. One should not confuse such color banding with laminations (which would indicate an absence of bioturbation).

The apparent completeness of its section makes Site 805 most valuable as a lysoclinal monitor of carbonate preservation through the entire Neogene and back into the upper Oligocene.

\section{Site 806}

Three holes were drilled at Site $806\left(0^{\circ} 19.1^{\prime} \mathrm{N}, 159^{\circ} 21.7^{\prime} \mathrm{E}\right.$; water depth, $2520 \mathrm{~m}$ ), with the deepest reaching upper Oligocene nannofossil chalk before being terminated at $776.4 \mathrm{~m}$ (see Table 1 for drilling and recovery statistics). The seismic record

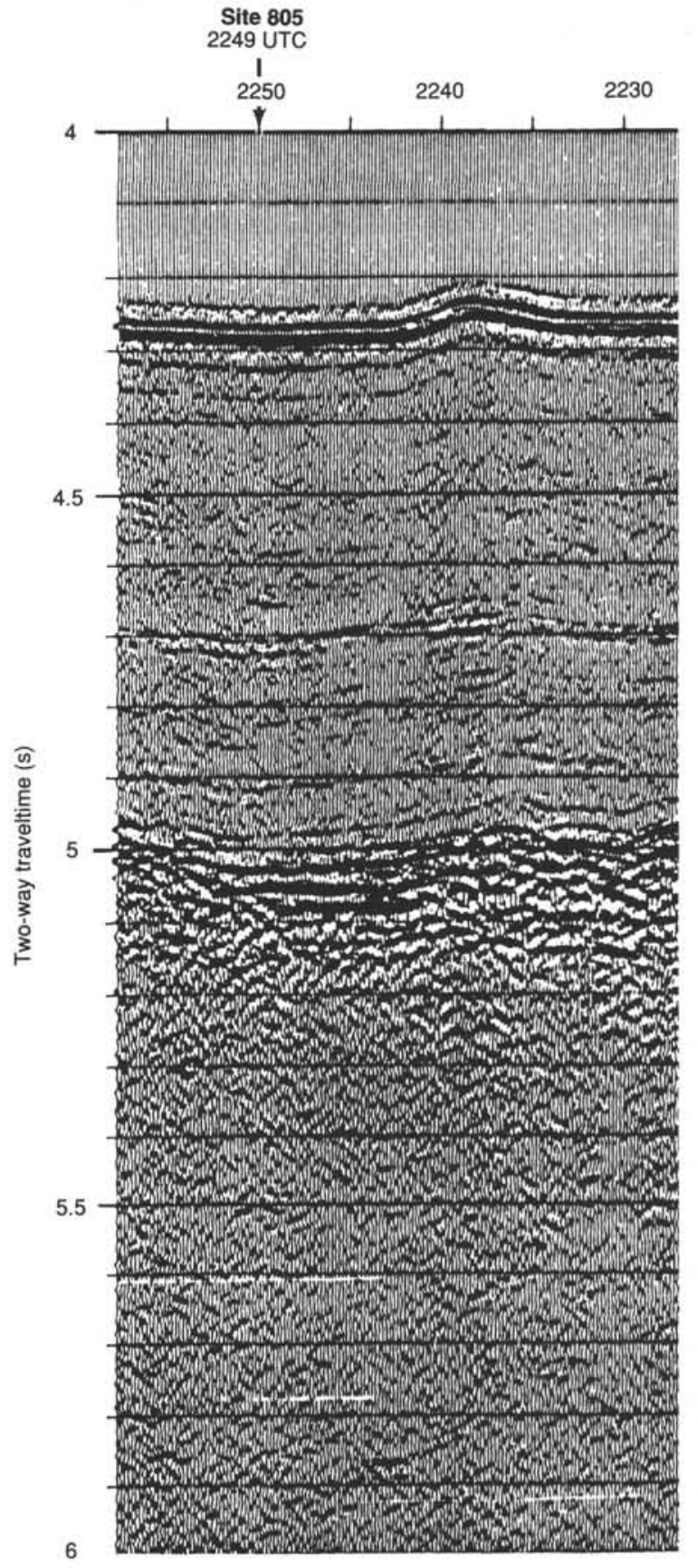

Figure 9. Seismic record at Site 805 , collected by the JOIDES Resolution before drilling, using the 80 -in. ${ }^{3}$ water gun, $25-250 \mathrm{~Hz}$ band-pass filter.

shows an undisturbed sediment section having an acoustic thickness of 1.00-1.05 s TWT (Fig. 11).

The sediment retrieved is Neogene in age, except for the four deepest cores in Hole 806C, where Oligocene chalk was recovered. The entire column, from the oldest deposits recovered to the seafloor, was considered as one lithologic unit and was classified as foraminifer nannofossil ooze and chalk to nannofossil ooze and chalk with foraminifers. No stratigraphic breaks were detected; apparently, the depositional history was continuous from the upper Oligocene (about $27 \mathrm{Ma}$ ) to the present. The average sedimentation rate over the entire Neogene has been esti- 

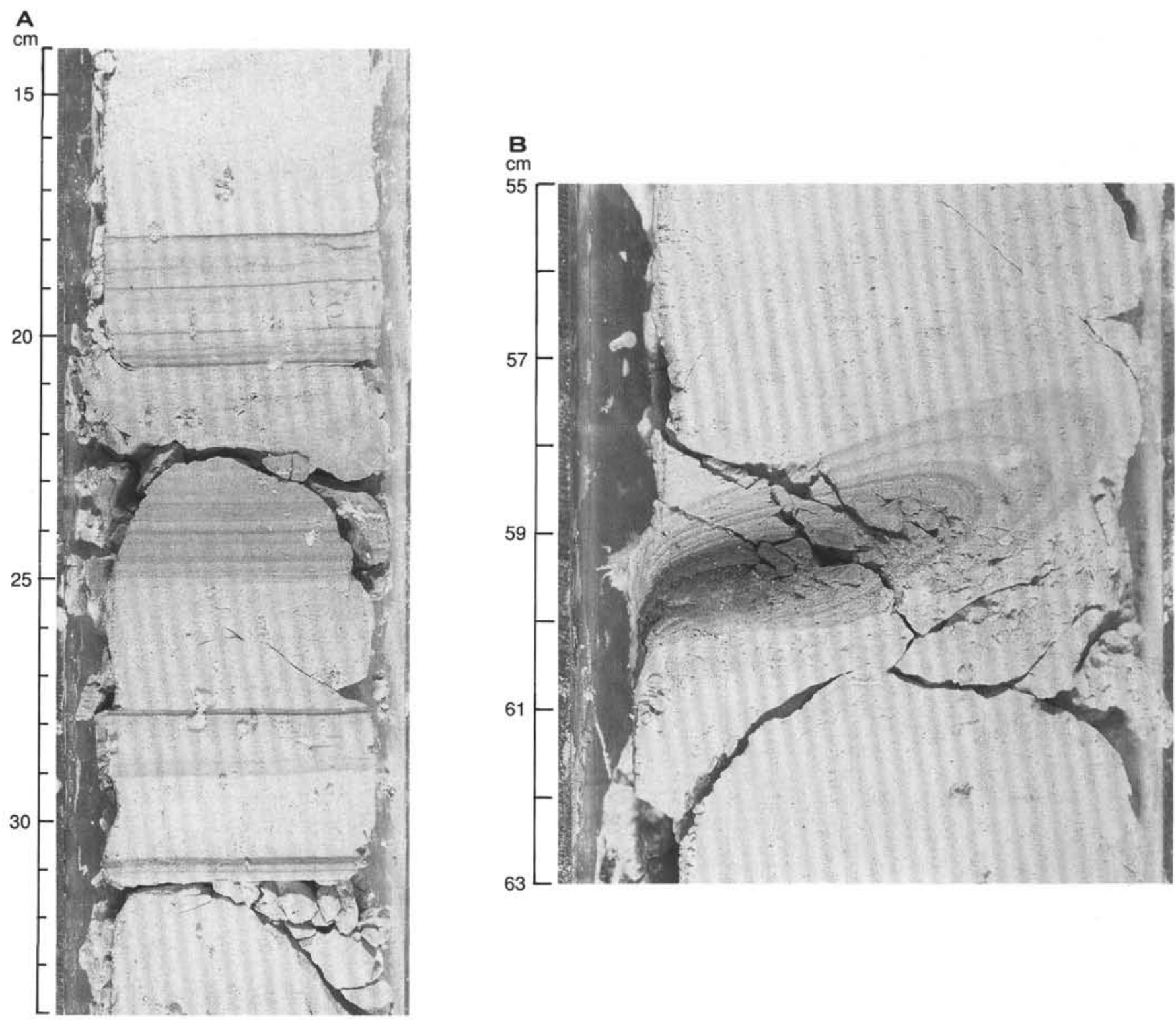

Figure 10. Fine-scale color banding in lower Miocene nannofossil chalk, Site 805, demonstrating (A) the formation of drilling lacunae (Interval 130$805 \mathrm{~B}-45 \mathrm{X}-6,14-34 \mathrm{~cm})$. B. The banding is analogous to the more familiar Liesegang rings (Interval 130-805B-46X-1, 55-63 cm).

mated as $31.6 \mathrm{~m} / \mathrm{m} . \mathrm{y}$, the highest rate of any site drilled during Leg 130. Depending on assumptions made about the age of biostratigraphic tie-points, the range of fluctuation lies between 15 and $55 \mathrm{~m} / \mathrm{m} . \mathrm{y}$. or between 20 and $45 \mathrm{~m} / \mathrm{m} . \mathrm{y}$.

We placed the ooze-chalk transition at 339 mbsf (lowermost upper Miocene, about $10 \mathrm{Ma}$ ). This transition is gradational and shows alternating layers of varying degree of lithification below about 200 mbsf. Again, the boundary was used to distinguish two subunits within the ooze-chalk sequence. Foraminifer content is significantly higher here than at Sites 803,804 , or 805 , which we estimated as between $15 \%$ and $30 \%$, on average. The completeness of the section at Site 806 and the excellent preservation of calcareous fossils, especially the abundantly occurring foraminifers, make this site extremely valuable as a standard against which to compare the other stratigraphies.

We obtained excellent logs for sound velocity and density for all except the uppermost part of Site 806 . Laboratory velocities and bulk densities provide control for the upper portion of the record, which could not be logged.

\section{Site 807}

Three holes were drilled at Site $807\left(3^{\circ} 36.4^{\prime} \mathrm{N}, 156^{\circ} 37.5^{\prime} \mathrm{E}\right.$; water depth, $2805 \mathrm{~m}$ ), with the deepest one penetrating the entire sedimentary section and well into basement (dated as Early Cretaceous) and terminating at $1528.4 \mathrm{mbsf}$ (see Table 1 for drilling and recovery statistics). The seismic record shows an undisturbed upper section and a somewhat disturbed lower section in a basement graben. The acoustic thickness is near $1.15 \mathrm{~s}$ TWT (Fig. 12).

The sediments recovered range in age from Pleistocene to Early Cretaceous; these were divided into three lithologic units. Unit I (0-968.0 mbsf) is composed mainly of Pleistocene to upper/middle Eocene nannofossil ooze and chalk with foraminifers, with lesser amounts of foraminifer nannofossil ooze and chalk as well as nannofossil ooze and chalk. Unit II (968.0$1351.4 \mathrm{mbsf}$ ) is composed of upper/middle Eocene to upper Campanian limestone, chert, nannofossil chalk, and nannofossil chalk with foraminifers. Unit III (1351.4-1379.7 mbsf) is 


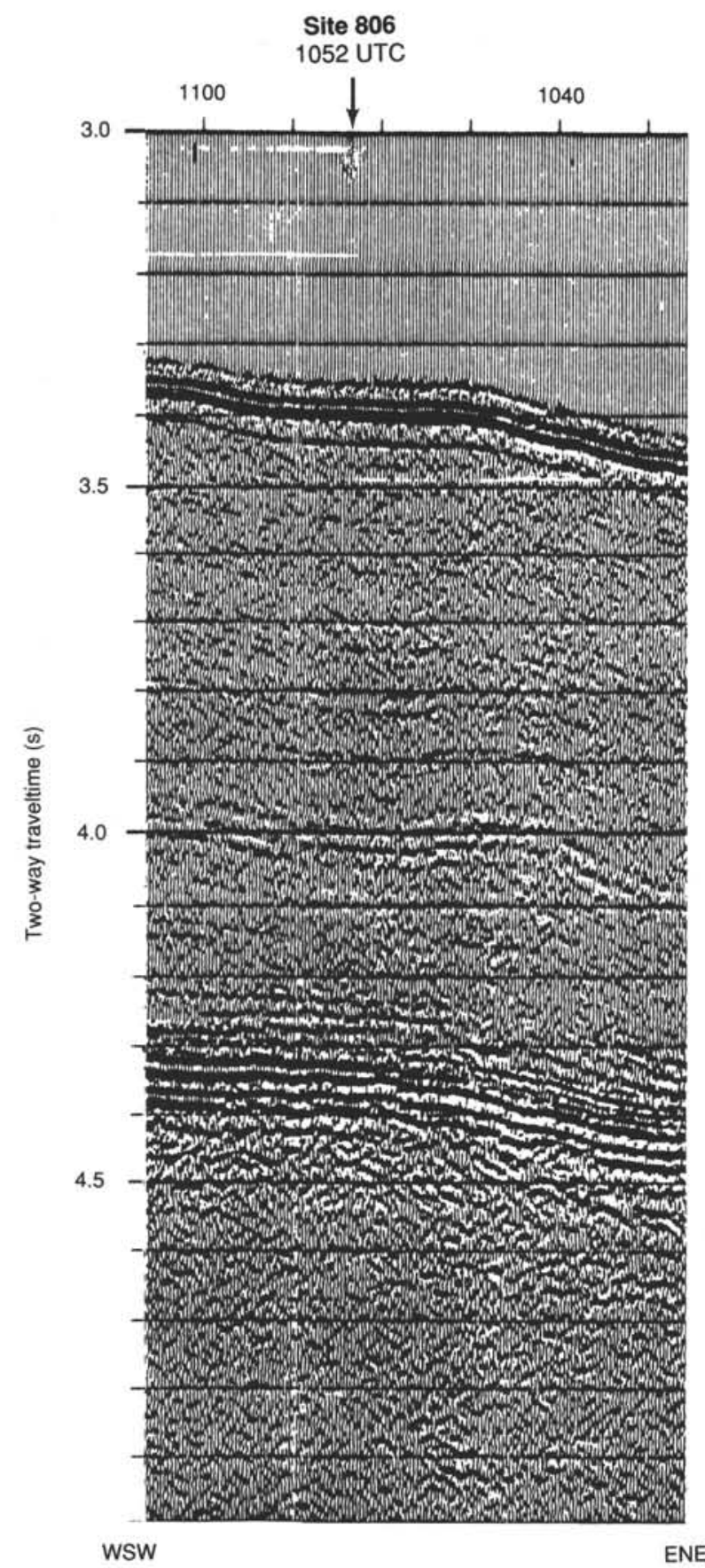

Figure 11. Seismic record at Site 806, collected by the JOIDES Resolution before drilling, using the 80 -in. ${ }^{3}$ water gun, $25-250 \mathrm{~Hz}$ band-pass filter.

composed of lower Cenomanian to upper Albian-Aptian(?) claystone, siltstone containing varying amounts of radiolarians, and limestone. Igneous basement at Site 807 is represented by one lithologic unit, Unit IV (1379.7-1528.4 mbsf), which is predominantly composed of Albian-Aptian(?) basalt.

The record is continuous from the Pleistocene to the upper Oligocene, at which time a stratigraphic break occurs at 702.4 mbsf (about 28-30 Ma), the first of three stratigraphic breaks that were encountered above the $\mathrm{K} / \mathrm{T}$ boundary. Other breaks occur in the middle Eocene at 991.9 and 1094.8 mbsf (about 40-43 Ma and 47-50 Ma). Much of the Paleocene to middle Eo-

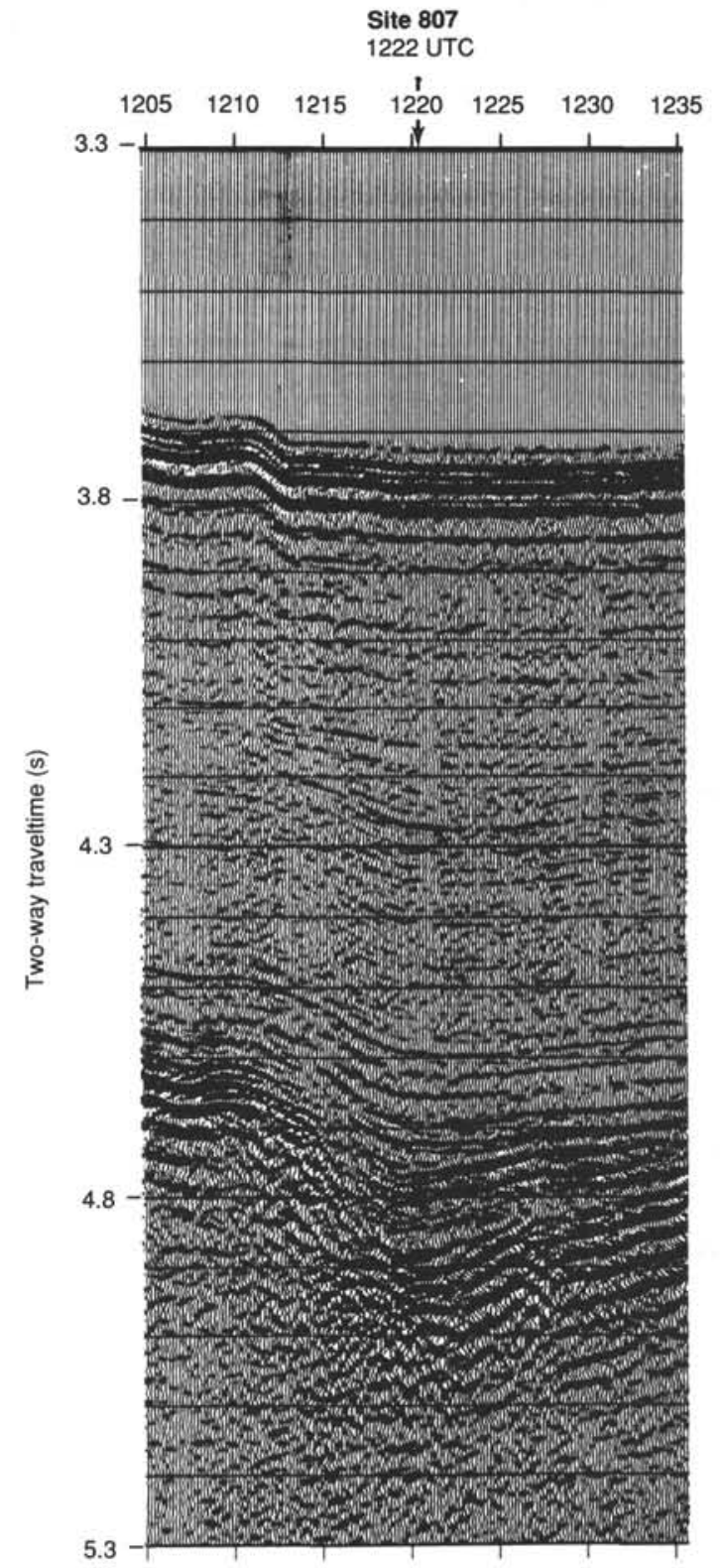

Figure 12. Seismic record at Site 807, collected by the JOIDES Resolution before drilling, using the 80 -in. ${ }^{3}$ water gun, $25-250 \mathrm{~Hz}$ band-pass filter.

cene section is condensed, with the exception of part of the upper Paleocene. The lower Paleocene also is condensed. The K/T boundary was crossed at $\mathbf{1 1 9 3 . 2}$ mbsf, with an apparently complete boundary sequence recovered within limestone. The section below the K/T boundary also includes one or more stratigraphic breaks, in particular between the upper Campanian limestone and the lower Cenomanian claystone-siltstone sequences at 1351.4 mbsf and near the Aptian-Albian limestone-basalt contact encountered at 1379.7 mbsf.

The depth of the ooze-chalk transition within Unit I was placed at 293 mbsf (about 10.4 Ma), where it separates Subunits IA and IB. This transition is not well defined and includes the lower $30 \mathrm{~m}$ of Subunit IA and the upper $20 \mathrm{~m}$ of Subunit IB. Silicified limestones and chert appear in Unit II below $968 \mathrm{mbsf}$, first interbedded with chalk and deeper down without chalk (below $1098 \mathrm{mbsf}$ ). The limestone has stylolites in places that 
form on clay-rich surfaces (Fig. 13). The sediments of Unit II, which range from the upper Eocene to the upper Campanian, are underlain by Subunit IIIA (1351.4-1369.7 mbsf), which is characterized by interbedded claystones and radiolarian-bearing siltstones (lower Cenomanian to upper Albian). Below these deposits, limestone and chert are predominant (upper Albian to Aptian, 1369.7-1379.7 mbsf).

Unit IV (1379.7-1528.4) is composed of Albian-Aptian tholeiitic basalt and interbedded limestone and has been divided into seven subunits, five of which are igneous and two of which are sedimentary.

\section{NEOGENE DEPTH TRANSECT}

\section{Goals and Setting}

For a good part of its Neogene history, the Ontong Java Plateau was located near the equator, where production of biogenous sediments has been unusually vigorous. Thus, rates of supply to the seafloor are high and provide an expanded carbonate record. On the upper portions of the plateau, sediments have been affected little by the dissolution of carbonate; however, on the lower portions of the flanks, these have been affected. The contrast between these sections provides clues to the saturation history of the deep Pacific, hence, to that ocean's carbon cycle. Carbonate sedimentation is strongly cyclic and is closely tied to climatic fluctuations (Moore et al., 1977). Thus, each individual record also provides clues to climate history.

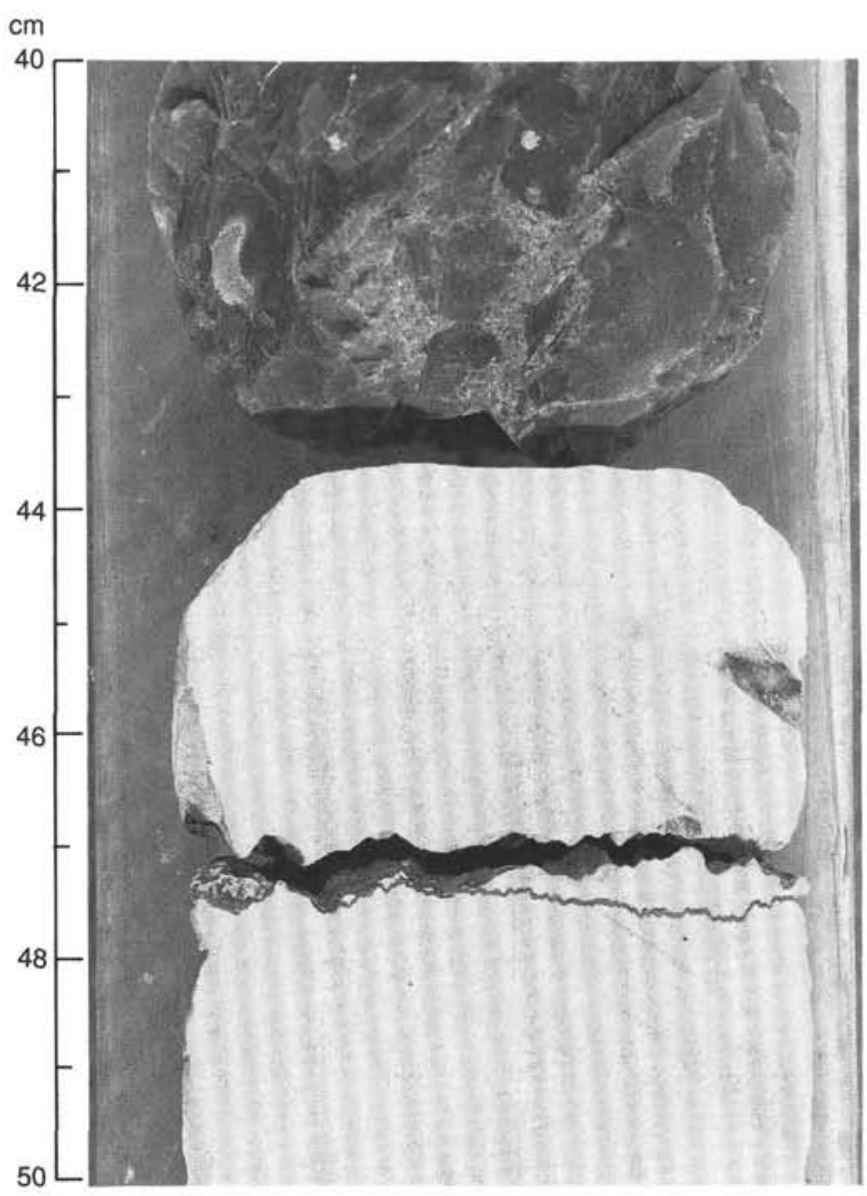

Figure 13. White limestone of Paleocene age showing parting along a stylolite surface. Chert is present in this section but not in abundance (Interval 130-807C-53R-3, 40-50 cm).
On a global scale, the carbonate deposited by the global ocean must equal the carbonate influx in the ocean. Thus, carbonate productivity and carbonate dissolution are linked through the requirement that carbonate supplied to the seafloor in excess of influx must be redissolved. Therefore, a general increase in production increases the overall dissolution rate. In contrast, on a regional scale, an increased supply of pelagic carbonate results in increased carbonate deposition and a deepening of the carbonate-compensation depth (CCD), as is observed along the equator (Arrhenius, 1952; Berger and Winterer, 1974; van Andel et al., 1975). Regionally, then, increased production results in the increased accumulation of carbonate. Consequently, the deposition rates of calcareous sediments of the Ontong Java Plateau include both a global and a regional signal with respect to ocean productivity.

In addition, signals reflect the regional dynamics of physical oceanography, especially bottom-water flow. Evidence exists for regular fluctuations in conditions that affect sediment composition and for abrupt change and/or reorganizations in the structure of supply, dissolution, and mechanical disturbance. These fluctuations and steps are of great significance in any attempt to understand the workings of the ocean system, that is, its role in climatic change.

A major goal of Leg 130 was to collect a series of continuous sedimentary sequences down the northeastern flank of the plateau. The sites were chosen to minimize the effects of latitudinal productivity gradients and to provide a means for evaluating the vertical distribution of a range of parameters of paleoceanographic significance, including physical properties, isotopic compositions, and micropaleontologic abundances. Shipboard studies permit the preliminary comparison of depth series of two important parameters: sedimentation rate and carbonate content (Fig. 14).

The most striking features of the sedimentation rate patterns are (1) the late Miocene to early Pliocene maximum and (2) the fact that equatorial position seems to have little influence on the patterns. A striking feature of the carbonate record is that so little difference exists among sites, although amplitudes of fluctuations increase with water depth, as expected. In the following, we elaborate on these observations.

Two sites are especially well suited for comparisons along a depth gradient: Sites 805 and 806 . Each offers an apparently unbroken record for the last $25 \mathrm{~m}$.y. These two sites are close enough to the equator to compare directly the quantity and quality of the supply of sediment, so that differences can be ascribed to depth of deposition without reservations. A third site (807) also appears to have a complete record, but its latitudinal position is distinctly different, implying a difference in supply of sediment to the seafloor. In turn, about 12-16 m.y. ago, this latter site recorded equatorial conditions, whereas the others were farther south, reflecting the general northward motion of the Pacific Plate.

The two remaining sites (803 and 804$)$ also contain important information about depth effects: they are located below the lysocline, so that exposure to carbonate dissolution is severe. However, this also makes these sequences more susceptible to removal of entire sections. Substantial hiatuses were detected; however, more may be present.

\section{Sedimentation Rates}

Sedimentation rates are derived from ages assigned mainly on the basis of inspection of core-catcher samples, largely following the zonal scheme of Berggren et al. (1985). Calcareous nannofossils and planktonic foraminifers provide the main chronological framework (Fig. 15). In many cases, estimated Cenozoic ages are associated with serious uncertainties because of a lack, or limited availability, of adequate magnetostratigraphic 


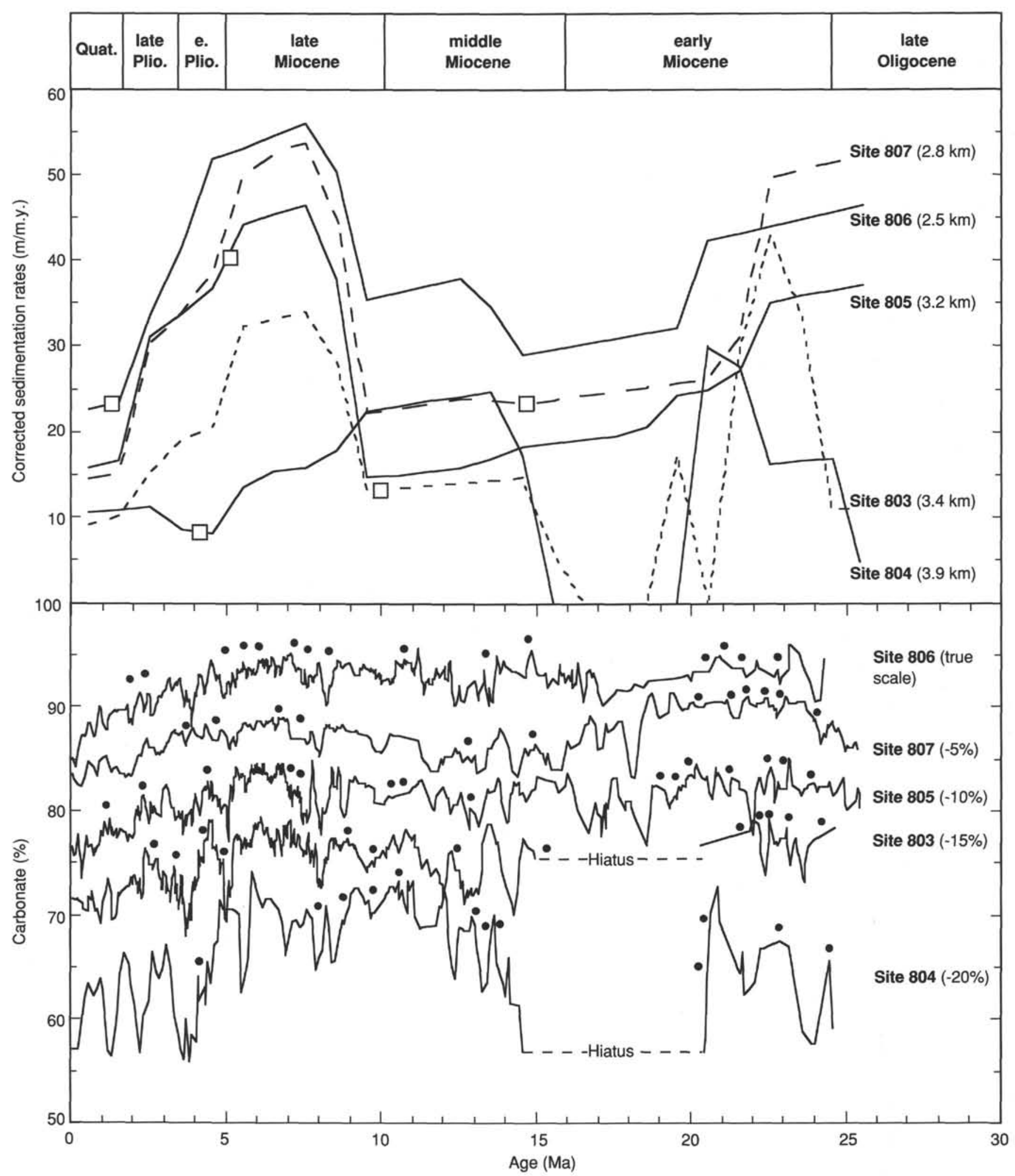

Figure 14. Sedimentation rates and carbonate percentages, Leg 130 sites. Sedimentation rates have been corrected for compaction (i.e., the density of Pleistocene sediments is assumed throughout for the calculation). Water depths for each site are listed on the right-hand side of the sedimentation rate figure. Boxes on the sedimentation rate curves indicate the time when the site crossed the equator. Carbonate percentages were shifted as indicated to aid graphical presentation. The dots associated with the carbonate curves indicate the approximate positions of individual acoustic reflectors. 


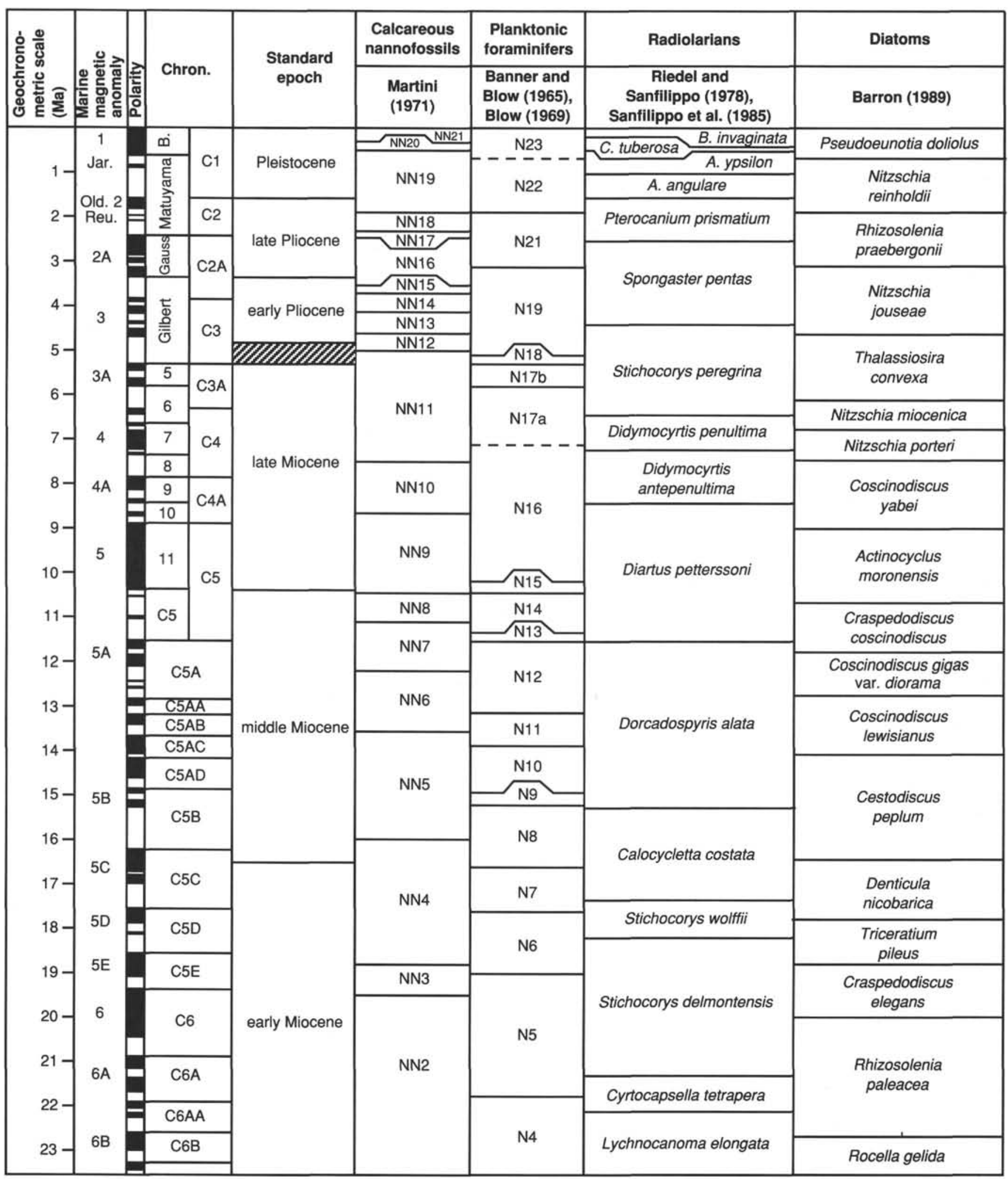

Figure 15. Biostratigraphic scheme for the Neogene, used during Leg 130. Drawn by Mark Leckie. See "Explanatory Notes" chapter (this volume) for sources of references given in the figure. 
records from tropical environments. Unfortunately, the cores recovered during Leg 130 proved to be unsuitable for constructing detailed magnetostratigraphies for sections older than the upper Pliocene. The high productivity near the equator, and the resulting diagenetic processes, apparently are inimical to the preservation of signals pertaining to geomagnetic polarity history. Thus, problems of resolution in dating must be kept in mind when contemplating the history of sedimentation rates: small changes in the age control points can substantially change the picture.

The overall sedimentation rate pattern for the last $25 \mathrm{~m} . \mathrm{y}$. is best reflected in that of Site 806 (Fig. 16). This site is dominated by a distinct low in the late early to early middle Miocene (ca. 20-15 Ma) and a prominent peak in the late Miocene to earliest Pliocene. As mentioned, equatorial position apparently does not influence major trends strongly. The period of low rates is characterized by hiatus formation at Sites 803 and 804, suggesting a causal association between rate reduction and sediment removal.

The onset of the low rate period after $20 \mathrm{Ma}$ corresponds to the beginning of a long period dominated by a highstand in sea level, according to the sea-level curve of Haq et al. (1987). This period also roughly coincided with a major excursion in the carbon isotope composition of the ocean (Vincent and Berger, 1985), which marked a strong increase in coastal ocean production. Thus, it appears that the early Neogene carbonate drought had global causes: the lack of supply from continents and the sequestration of carbon on shelves and in margins.

The upper Miocene sediments display some of the highest rates yet recorded in open-ocean pelagic sediments. The timing of this carbonate flood suggests a strong relationship to major phases in mountain building. An increase in supply from emerging continents must be assumed: lowstands of sea level characterize the period (Vail and Hardenbol, 1979; Haq et al., 1987). Cooling and an increase in trade winds, and hence in equatorial

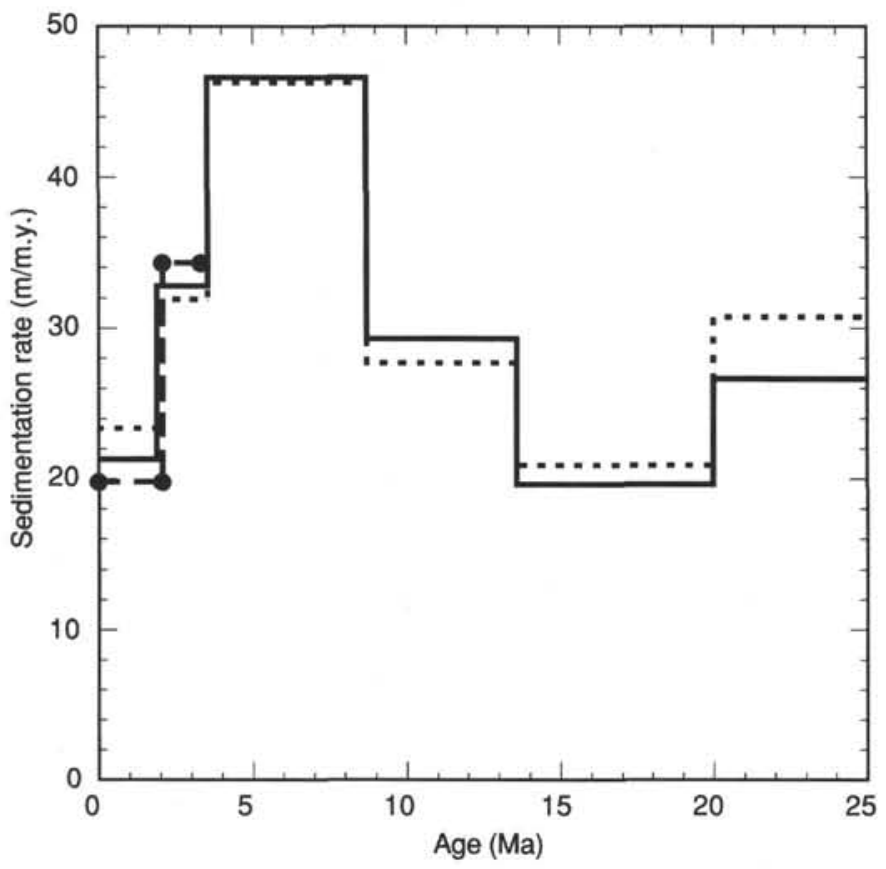

Figure 16. Sedimentation rates for Holes 806A, 806B, and 806C, based on the ratio of sediment thickness to the biostratigraphic time interval (uncorrected for compaction). Note the differences from hole to hole. Dashed line with filled circles $=$ Hole 806A, solid line $=$ Hole 806B, and dashed line $=$ Hole 806C. Drawn by Jan Backman. upwelling, is likely as well, an interpretation supported by the optimal preservation of diatoms in the interval. A strong eastwest gradient in productivity developed during this time in the equatorial Pacific (Leinen, 1979; Kennett, 1985), an asymmetry that has implications for the dynamics of the equatorial undercurrent (Barron and Baldauf, 1989) and, indeed, for the entire equatorial system (Flohn, 1985).

The remarkable decrease in carbonate accumulation in the Pliocene, and especially in the Quaternary, was accompanied by decreasing diatom and radiolarian preservation. This decline may reflect decreased production from the removal of nutrients and silica, presumably by coastal-ocean pumping in response to increased seasonal upwelling generated by monsoonal winds. The equatorial upwelling mill, driven by strong trade winds, turned as fast as ever, but its grist was diminished, being trapped in the ocean margins. Alternatively, or in addition, the increase in northern trade winds (the southern ones being strong already) now led to a pile-up of shallow warm water in the western Pacific, making the upwelling process less efficient by deepening the thermocline. There are indications from the increased difference in the oxygen isotope values of Globigerinoides sacculifer and Pulleniatina obliquiloculata, 2 m.y. ago at Site 586, that this mechanism was indeed important (Whitman and Berger, in press).

An increase in foraminifer content during the latest Neogene suggests yet another factor for reducing sedimentation rates: increased winnowing. Resuspension of fine material (that is, nannofossils) by bioturbation and local turbulence presumably is a ubiquitous process. The resuspended material imparts increased density to bottom-contact waters, which flow downhill in response, creating a type of katabatic flow familiar from cold air in contact with glaciers. Katabatic deep-sea currents should be favored during lowstands of sea level. Tidal energy is most readily destroyed in shelf seas, which are greatly diminished during periods of lowered sea level. Thus, this energy is available for enhancing tidal currents in the deep sea, which would help in keeping fine-grained material suspended (even if not powerful enough to create resuspension). Transport would be from shallow depths to greater ones, where dissolution would remove the advected material. One corollary of such a process is increased alkalinity of the ocean, which would have the effect of reducing the atmospheric $\mathrm{CO}_{2}$ content.

The orderly arrangement of sedimentation rates among sites since the middle Miocene, according to depth of deposition, indicates a strong carbonate saturation gradient, presumably established by the increasing influence of formation of cold deep water. That the position relative to the equator seems unimportant is surprising. Again, we recall the earlier caveat about assigning biostratigraphic ages before attempting to interpret details of these curves. A sense of the changing ratios in sedimentation rates, independent of exact time scale, may be obtained by assuming that Site 806 is standard and by expressing the rates of the other sites as fractions (i.e., thickness ratios; see Table 2).

The overall change in thicknesses for the Neogene is a function of the water depth, as expected. However, trends between the different periods are by no means identical. An interesting reversal occurred between Sites 805 and 807 during the early Miocene, which may disappear, however, when one corrects for compaction (Fig. 14). There is a maximum difference in the sedimentation rates between Sites 805 and 806 during the late middle Miocene (Fig. 14), which affects the thickness ratio for the middle Miocene, making it unusually low $(0.59)$. The two sublysoclinal sites also have low ratios for this interval, but not Site 807. Again, correction for density differences and refinements of biostratigraphy may change this picture. Assuming that the trend is real, one should consider that the late middle Miocene was a time of globally shallowed CCD (Berger and Winterer, 
Table 2. Sediment thickness ratios of Leg 130 sites.

\begin{tabular}{llllll}
\hline Site & 806 & 807 & 805 & 803 & 804 \\
\hline Depth $(\mathrm{km})$ & 2.5 & 2.8 & 3.2 & 3.4 & 3.9 \\
Pleistocene & 1.0 & 0.70 & 0.73 & 0.40 & 0.38 \\
late Pliocene & 1.0 & 0.88 & 0.88 & 0.51 & 0.35 \\
early Pliocene & 1.0 & 0.73 & 0.71 & 0.38 & 0.14 \\
late Miocene & 1.0 & 0.86 & 0.67 & 0.58 & 0.47 \\
middle Miocene & 1.0 & 0.78 & 0.59 & 0.31 & 0.30 \\
early Miocene & 1.0 & 0.80 & 0.87 & 0.41 & 0.35 \\
Neogene & 1.0 & 0.80 & 0.72 & 0.43 & 0.35 \\
\hline
\end{tabular}

Note: Denominator $=$ Site 806 .

1974). Thus, one may infer that increased production (Site 806) was compensated by increased dissolution in the deeper sites (Sites 803, 804, and 805). This compensation may reflect negative feedback to achieve global carbonate balance (van Andel et al., 1975), or it may represent a fortuitous combination of regional and global effects.

\section{Carbonate Stratigraphy}

The carbonate curves (Fig. 14) show broad coherency, as well as good correlation in detail, at least back to about 12 m.y. ago. The deeper sites show the lower values and the larger fluctuations, as one would predict. The increased range of fluctuations in the sublysoclinal sites, as compared with the shallow ones, suggests a strong imprint from changes in dissolution rates.

We note that correlations in carbonate content are good for the last $12 \mathrm{~m} . \mathrm{y}$. and are poor earlier. In part, spotty sampling in the earlier sections may be responsible, and greater sampling density will be necessary to find the exact change in the quality of correlations as a function of time. It appears that fluctuations in carbonate increase in amplitude within the upper Miocene sediments, especially during post-Miocene time, and that such fluctuations are strongly felt, even within the shallowest site (806). Two especially large oscillations can be seen between 9 and $8 \mathrm{~m} . y$. ago, at the exact time when sedimentation rates increased sharply (Fig. 14).

One outstanding problem is why the carbonate values of the deeper sites differ so little from the high values of the shallower sites. A detailed comparison of Site 806 with Site 805 (Fig. 17) shows that these differences vary only between $0 \%$ and $3 \%$ on the whole, although the differences in depth and in sedimentation rates (Fig. 14) are not subtle at all. Despite the small amplitude of the carbonate fluctuations and the small difference between the two sites, the patterns track closely, suggesting a cause active over a large depth interval. Assuming that fluctuating dissolution intensity is the underlying cause, we have labeled the levels of sudden carbonate decrease "carbonate reduction events" (CREs) and numbered the main events with Roman numerals, going downhole in the usual fashion. Should CREs prove to be dilution events (which we think unlikely), the "reduction" would be strictly relative to the noncarbonate fraction.

If we assume that the difference in carbonate content between the two sites represents excess removal of carbonate at Site 805 and allow no other factors, we can calculate the expected ratio in sedimentation rates between the two sites. The sedimentation rate ratio (SRR) rarely falls below a value of 0.8 (Fig. 18, curve marked DISS; scale to right) for the last 15 m.y. The ratio seen in the biostratigraphy is distinctly smaller, with an average of nearly 0.67 for this same interval $(385 / 574$; see Fig. 4). Correlation of carbonate peaks with valleys also yields values for the SRR. On the whole, these are close to the ones obtained from biostratigraphy and, consequently, are distinctly below the ratios calculated on the basis of carbonate differences alone (Fig. 18, curve marked CORR). (It is true that accumula- tion rates should be compared, rather than sedimentation rates; here, we are neglecting the difference in gradient of porosity reduction, which introduces a small error: CORR and SRR are affected, whereas DISS is not.)

We conclude from this exercise that carbonate removal by dissolution alone cannot explain the differences in sedimentation rates among the sites as well as the differences in carbonate content. To explain the differences in sedimentation rates, sediment removal at Site 805 must be invoked. To explain the absence of a corresponding difference in carbonate, one must assume both the removal of carbonate and of dilutant. Thus, the pattern can be explained if one postulates that carbonate dissolution cannot proceed alone but implies the removal of noncarbonate dissolution as well.

Much more will be learned about this point by reconstructing sedimentation rates at high resolution using Milankovitch tuning. Shipboard measurements of physical properties, logging results, and stable isotope analyses to be performed onshore will be available for this purpose.

\section{SEISMIC STRATIGRAPHY}

\section{Goals and Setting}

One important objective of Leg 130 was to obtain data about the origin of the acoustic reflectors, which characterize the layercake stratigraphy on the plateau. Many of the reflectors seen at each individual site can be traced over considerable distances, and certain reflectors, or reflector groups, appear to be exactly equivalent from one site to the next. A selection of seismic profiles from different depths is shown in Figure 19 (see Mayer et al., this volume).

Reflectors in the area of DSDP Sites 289 and 586 had been tentatively dated, based on Site 289 drilling results (Shipboard Scientific Party, 1975b) and Site 586 logging results (Shipboard Scientific Party, 1986; see Fig. 20). An important objective of Leg 130 was to establish correlations of reflectors from sediments at greater depth into this published sequence, if possible, and to verify the age assignments.

It has been suggested that many of the reflectors are synchronous and represent diagenetically enhanced sediment contrast derived from previous conditioning of sediments on the seafloor by paleoceanographic events (Schlanger and Douglas, 1974). For the shallower reflectors, where diagenesis presumably is unimportant, abrupt changes in conditions of preservation alone were invoked as agents of reflector formation (Berger and Mayer, 1978), based on the knowledge that dissolution changes sand content and thus directly governs velocity within deep-sea carbonates (Johnson et al., 1977).

Taking a view simultaneously more general and more specific than these earlier studies, Mayer et al. $(1985,1986)$ proposed that in the central equatorial Pacific many of the major reflectors are associated with certain paleoceanographic events, with or without diagenetic enhancement. They selected the closing of the Panama Isthmus, reorganization of deep circulation in the Atlantic, climatic events in the Antarctic, and the opening of the Drake Passage as important paleoceanographic themes reflected in the acoustic stratigraphy of Pacific pelagic sediments (Table 3). In this general view, reflectors are the tangible largescale manifestations of major steps in Cenozoic ocean evolution, as driven by tectonics (Berggren and Hollister, 1977; Keigwin, 1978; Kennett, 1982, 1985) and by internal climatic feedback mechanisms translating tectonic change into climate steps (Berger et al., 1981). If it is true that globally important events can be seen in the seismic reflectors of the central equatorial $\mathrm{Pa}$ cific, then these events should be similarly represented in the sediments of the western equatorial Pacific, even though the 

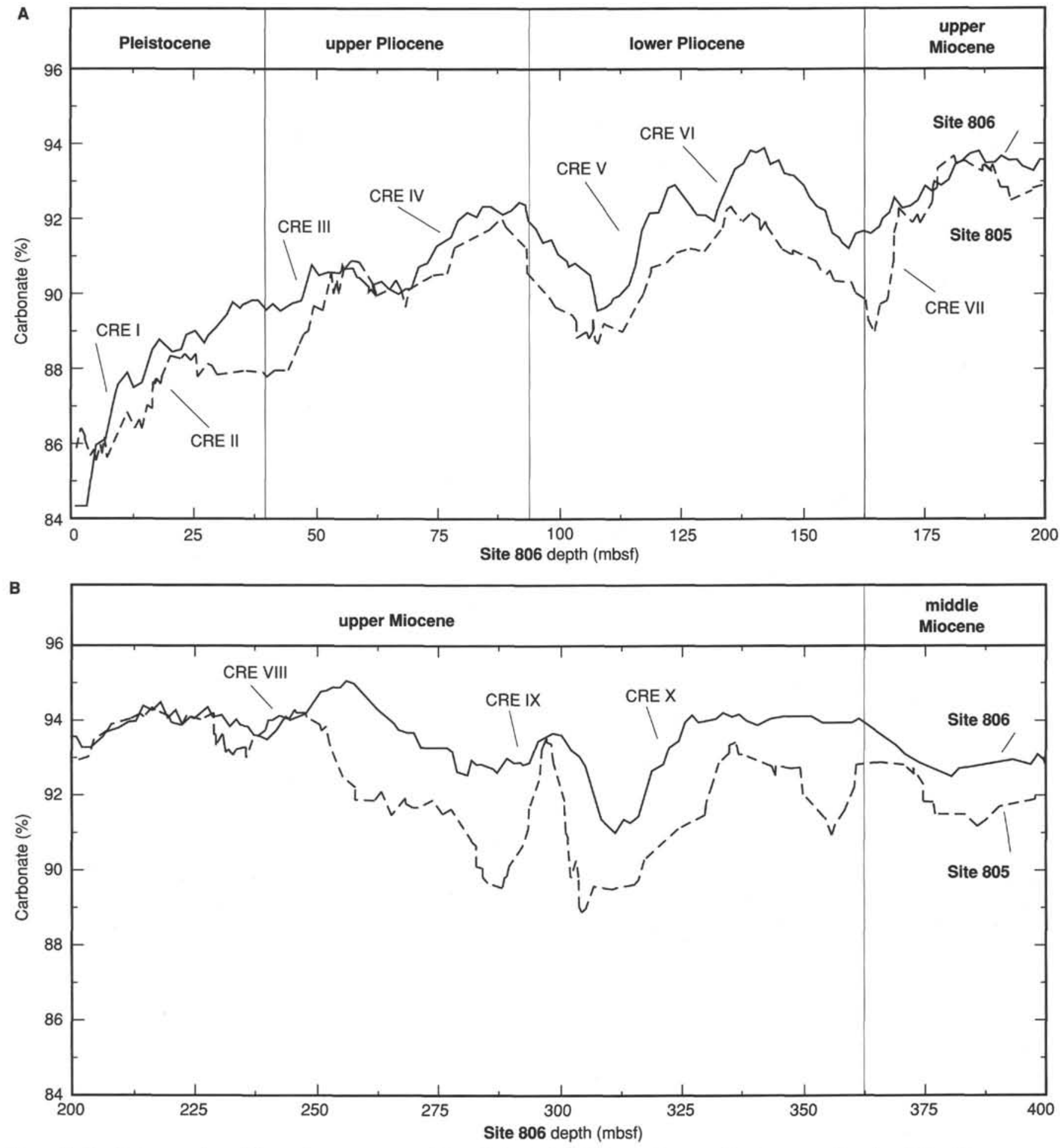

Figure 17. Detailed comparison of the carbonate contents of Sites 806 and 805 . CRE = carbonate reduction event. Mapping of Site 805 pattern on the Site 806 pattern was done by eye. Based on measurements by R. Stax; drawn by E. Jansen.

physical causes for generating the echo potential might be different in these shallower and more carbonate-rich sediments.

The task is to map the reflectors for each site by seismic profiling and to assign them to the correct depth in the sediment column, using the appropriate downhole velocity profile. Based on both density and velocity profiles, a synthetic seismogram can be generated (Mayer et al., 1985) that will simultaneously express the expected position and strength of the reflectors (Fig. 21). Matching the synthetic profile with the real profile provides a powerful test of the correctness of the depth assignments. Bio- 


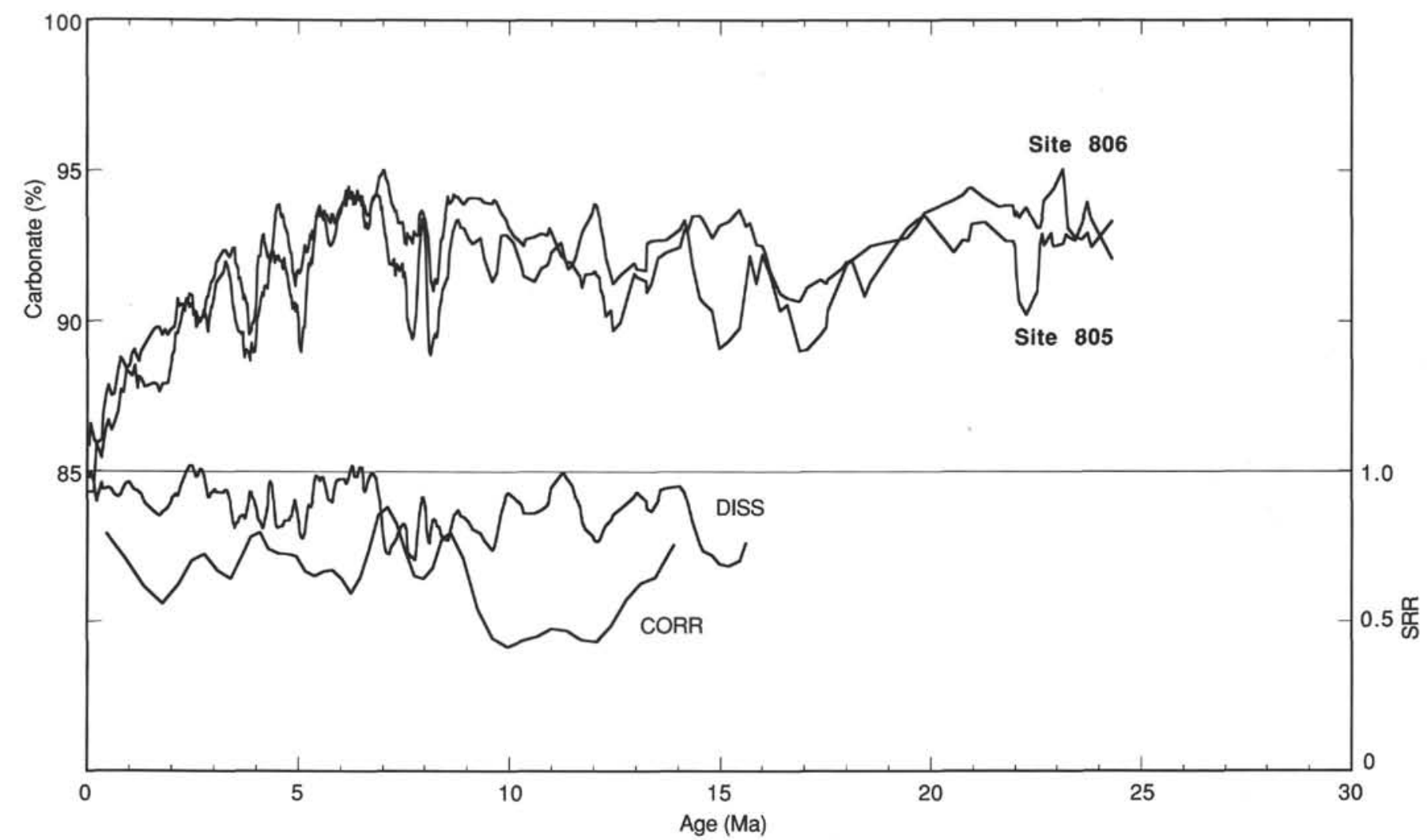

Figure 18. Sedimentation rate ratios from carbonate stratigraphy. Top: carbonate curves for Sites 805 and 806 . Bottom: sedimentation rate ratios (SRRs) calculated from the differences between carbonate contents (DISS) and from mapping the curve of Site 805 over that of Site 806 (CORR).

stratigraphic dating provides ages for the reflectors. Detailed sedimentologic, paleontologic, and chemostratigraphic studies allow one to assess the paleoceanographic significance.

\section{Sites 803 and 804}

Like all the other sites, Site 803 is characterized by a layercake seismic stratigraphy (Fig. 5). In this region, disturbances commonly interrupt the regular layering. The prominent feature seen between 4.8 and $4.9 \mathrm{~s}$ TWT is discussed as "mid-section reverberation" (MSR) in the "Site 803" chapter (this volume). The level of an ash layer apparently corresponds to the top of the MSR, which suggests that volcanism was associated with its formation. Elsewhere, there is some indication that these features are associated with faults in the basement and that they represent enhanced diagenesis (i.e., increased velocity). We suggest that the circulation of fluids through cracks in the basement during times of volcanism accelerated lithification, thus producing MSRs (i.e., these are "diagenetic dikes" or "diagenetic sills").

Many reflectors can be seen in the regular sequence of Site 803 . Nine single reflectors and two reflector groups have been marked with numbers from 3-1 to 3-11. Three minor reflectors are marked 3-a, 3-b, and 3-c. These marked reflectors have wellmatched counterparts in the synthetic seismogram that was generated from physical property and logging data for Site 803 .

From the ages of the reflectors, possible clues emerge regarding their paleoceanographic significance. Reflectors 3-1 and 3-2 occur at depths dated at 2.6 and 3.3-3.4 Ma, respectively. These periods are well established as steps of cooling and buildup of ice in the Northern Hemisphere (Backman, 1979; Shackleton et al., 1984). In nearby DSDP Site 586, oxygen isotopes have heavier values in both planktonic and benthic forms for both events (Whitman and Berger, in press). Marked changes in sand content and in carbonate content also are indicated. Presumably, the initiation of Northern Hemisphere glaciation was felt in this region through changes in productivity (caused by wind field changes; Arrhenius, 1952) and changes in bottom-water properties (increased activity of North Atlantic Deep Water [NADW], with corresponding downstream effects in the Pacific; Berger, 1970). These results are in good agreement with the propositions of Mayer et al. (1986; Table 3).

Reflectors 3-a and 3-b (at 4.3 and 5.0 Ma, respectively) are tied to strong changes in carbonate and sand content. Ice melting and warming trends are indicated in the oxygen isotope data for the 4.3-Ma event (Whitman and Berger, in press), and a major rise in sea level has been postulated for about this time (Vail and Hardenbol, 1979). The transition from the Miocene to the Pliocene is marked by a pronounced dissolution spike (Saito et al., 1975; CRE VII, Fig. 17A). Thus, for these reflectors, too, the paleoceanographic connection holds up well.

Reflector 3-c (at 9.7 Ma) corresponds to a major decrease in sea level (Vail and Hardenbol, 1979; Haq et al., 1987) and with a reorganization of much deep-sea sedimentation (an increase in the dust supply, an increase in NADW production, closure of the Indo-Pacific passage, a shift in silica to high-latitude sinks; see Janecek and Rea, 1983; Miller and Fairbanks, 1985; Romine and Lombari, 1985; and references therein). Hiatus formation is common near this level (NH4 of Keller and Barron, 1987). Reflector 3-4 (12.3-12.5 Ma) lines up with the NH3 level. Reflector 3-5 (15.8 Ma) coincides with a major hiatus at Site 803 and lines up with level NH2 of Keller and Barron (1987). The period between 16 and $15 \mathrm{Ma}$ can be characterized by major fluctuations in sea level (Haq et al., 1987) and by the initiation of major cooling of abyssal waters; that is, a major increase in Antarctic 


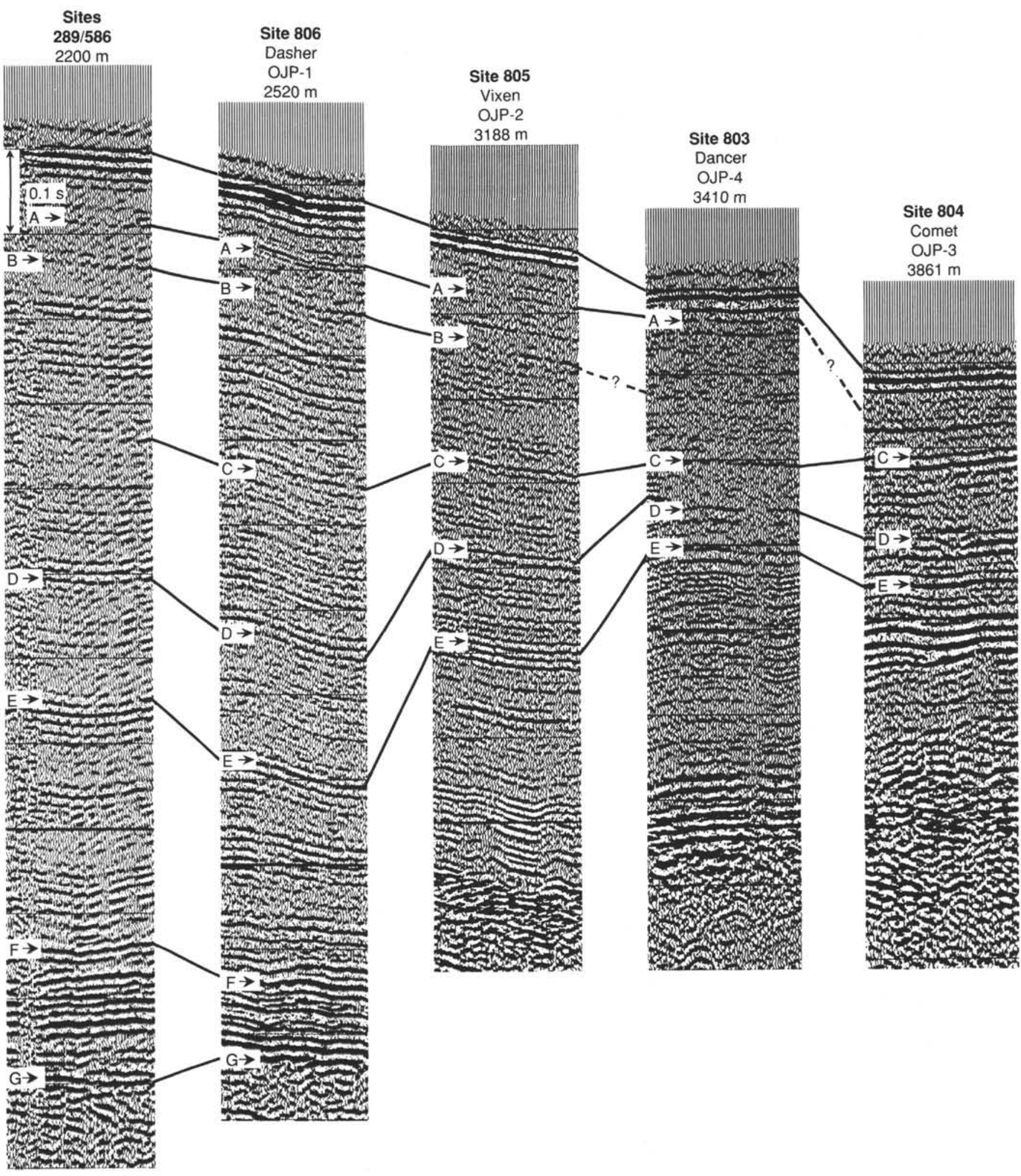

Figure 19. Relationships of seismic sections and marker reflectors down the flank of Ontong Java Plateau. Horizontal lines within each section represent $0.1 \mathrm{~s}$ of two-way traveltime. See Mayer et al. (this volume) for discussion of Reflectors A-G. 


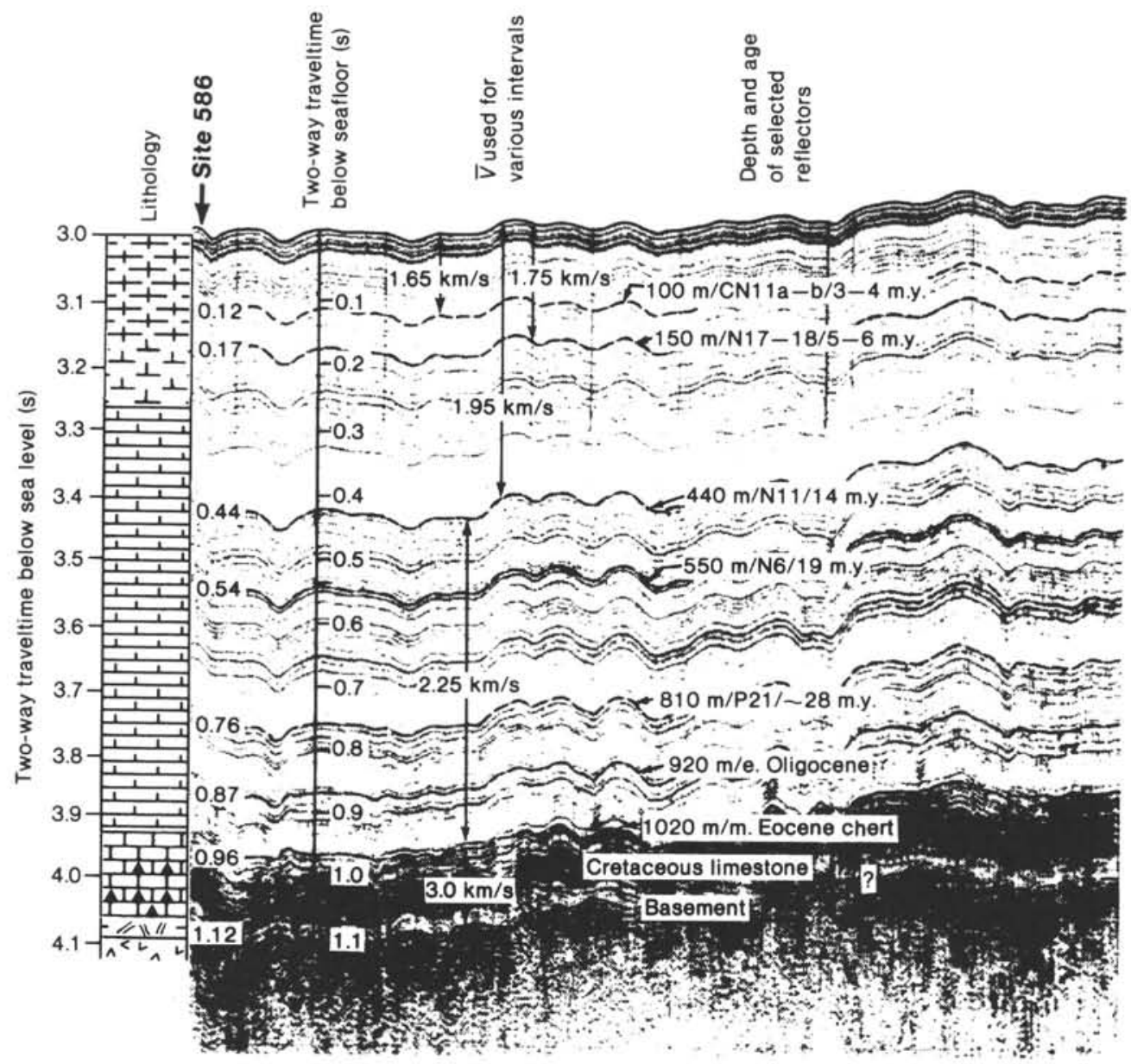

Figure 20. Interpretation of Leg 89 seismic profile over Site 586 (from Shipboard Scientific Party, 1986). Survey speed was $7 \mathrm{kt}$.

Table 3. Reflectors in the central Pacific and their paleoceanographic significance.

\begin{tabular}{cllll}
\hline $\begin{array}{c}\text { Approximate } \\
\text { age (Ma) }\end{array}$ & \multicolumn{1}{c}{$\begin{array}{c}\text { Geochemical } \\
\text { events }\end{array}$} & Hiatus & \multicolumn{1}{c}{$\begin{array}{c}\text { Paleoceanographic } \\
\text { events }\end{array}$} & $\begin{array}{c}\text { Primary cause } \\
\text { of relector }\end{array}$ \\
\hline $3.0-3.5$ & $\begin{array}{c}\text { Benthic }{ }^{18} \mathrm{O} \text { enrichment. } \\
\mathrm{CaCO}_{3} \text { dissolution. }\end{array}$ & & $\begin{array}{l}\text { Closing of Panama Isthmus. } \\
\text { North Hemisphere glaciation? } \\
\text { North Atlantic erosion. }\end{array}$ & Carbonate miminum. \\
Increased isolation of Mediterra- \\
nean Sea.
\end{tabular}

Note: Source of data is from Theyer et al. (1989). 


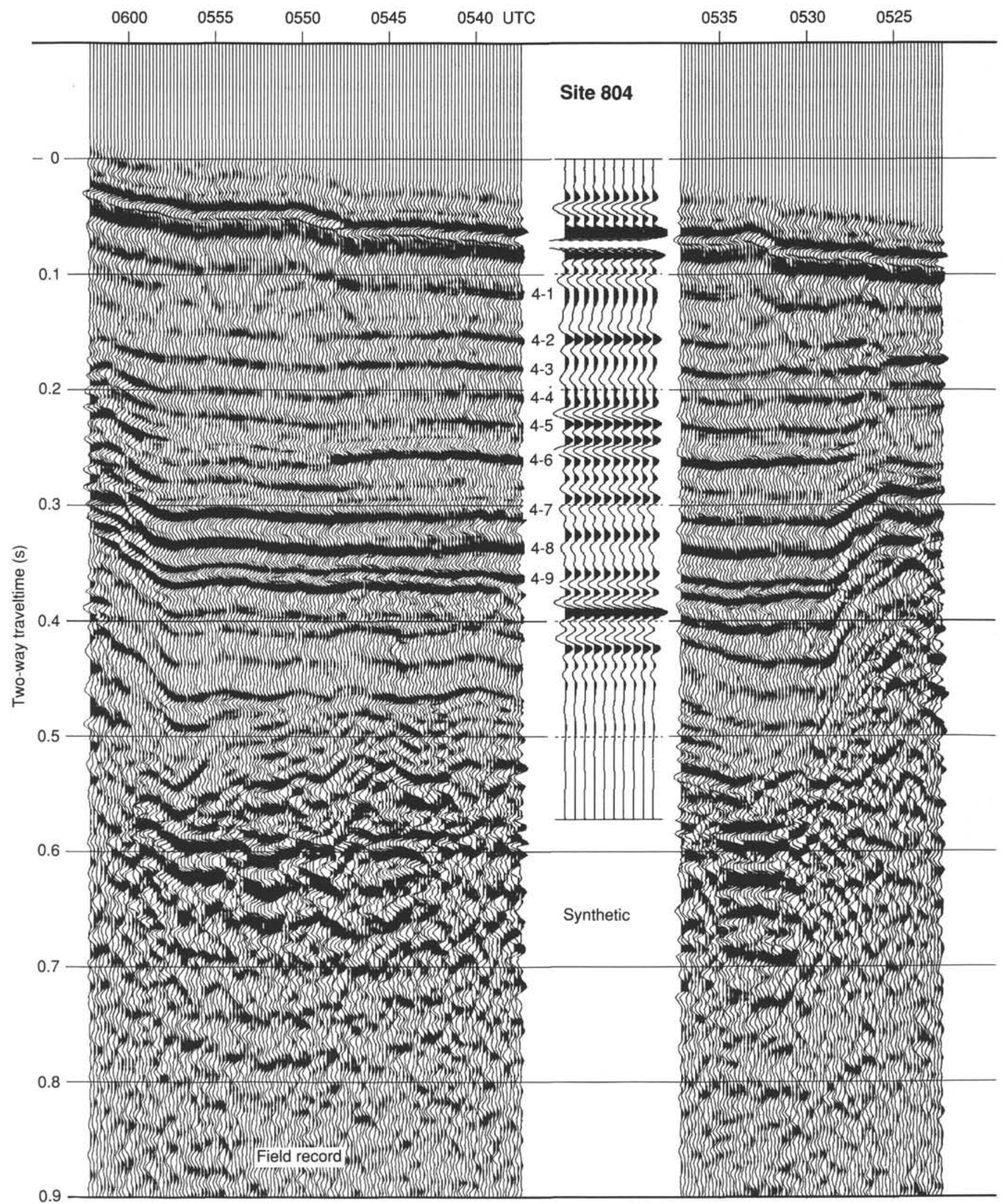

Figure 21. Comparison of synthetic seismogram and field record at Site 804. See text for discussion of reflector numbers. 
Bottom Water (AABW) production, as seen in benthic oxygen isotopes (Woodruff et al., 1981). Again, the hypothesis of Mayer et al. (1986) is supported by these findings.

Reflectors 3-6 and 3-7 are developed in the lowermost Miocene and uppermost Oligocene. They mark the transition between the Paleogene and Neogene, a period of great changes associated with the opening of the Drake Passage and the progressive thermal isolation of Antarctica. No particular events can be assigned to the individual reflectors in these groups at this time. We shall see similar groups in Sites 805 and 806 , which will be discussed in greater detail later. Reflector 3-8 and deeper ones are associated with the velocity jumps produced by the formation of chert and limestone.

Site 804 was not ideally suited for studying seismic stratigraphy; nevertheless, it contained some important lessons concerning the ease of correlation among the sites. Seismic profiles across the site (Fig. 21) show the effects of mass movement. These profiles exhibit disturbed crenulate reflections at several levels, as well as evidence for wedging along the basin margins. Disturbance is first clearly noticeable at $0.05 \mathrm{~s}$ below seafloor (sbsf; about $40 \mathrm{mbsf}$ ), where the lower Pliocene section seems to be condensed or missing (near $4.5 \mathrm{Ma}$ ). An unconformity occurs at that level or slightly below it. Disturbance continues down to 0.1 sbsf (about $80 \mathrm{mbsf}$ ) and also may include deeper intervals. This would correspond to the disruptions seen in the cores, especially at 70-80 mbsf (7-8 Ma).

Disturbance is seen again in the lower part of the block, near $0.21 \mathrm{sbsf}$ (about $170 \mathrm{mbsf}$ ). At $0.22 \mathrm{sbsf}$, there is a strong reflector. This reflector essentially coincides with the ooze-chalk transition, as located in the cores. Another reflector at 0.23 sbsf is probably a slip plane. In the cored sediments, a major hiatus is seen at this level (197 mbsf, 18.6-14.6 Ma). On either side of this plane, reflectors have been disrupted, presumably from mass movement. This series of strong reflectors probably represents ooze-chalk alternations in the lower Miocene.

The Miocene/Oligocene hiatus is well expressed as a strong double reflector, with the first return at $0.30-0.31$ sbsf (about $270 \mathrm{mbsf}$ ). Judging from the absence of strong reflectors below, a section of more than $100 \mathrm{~m}$ of lower Oligocene sediments might be expected here, with the (unconformable) Eocene/Oligocene boundary appearing near 0.42 sbsf. If so, another 200 , or perhaps $250, \mathrm{~m}$ of sediment (depending on where the basement reflector is assigned) would be expected in this graben before reaching basement. The first strong deep reflector (at 0.48 sbsf) presumably would mark the location of Eocene limestone and chert. Outside of the basin, the apparent paucity of pre-Oligocene deposits would suggest widespread erosion early in the Cenozoic and in the Late Cretaceous, as was the case at Site 803.

There is some indication that disturbance is associated preferentially with certain layers. This supports the hypothesis that such layers may be predisposed, through preconditioning during deposition, to serve as slip planes later. If so, the connection between reflectors and paleoceanographic events is strengthened, but also confused, because unconformities and slip planes will give the appearance of a complete sequence within a seismic section, even though the sequence is incomplete.

\section{Sites 805 and $\mathbf{8 0 6}$}

Sites 805 and 806 are similar with respect to their seismic records, except that the record is compressed by a factor of 0.73 on average in Site 805 . Both sites have complete records, without hiatuses. In fact, this is one of the reasons why correlation from one to the other is so readily accomplished (Fig. 22). A case can be made that many of the paleoceanographically significant reflectors identified at Site 803 also can be identified here. Taking advantage of this finding and following the general suggestions of Mayer et al. (1986) regarding the meaning of the reflectors in terms of global events, we now turn to the grouping of reflectors and their overall pattern.

Going back in time, the themes put forward by Mayer et al. (1985, 1986; Table 3) included (1) the closing of the Panama Isthmus and the concomitant reorganization of deep circulation in the Atlantic, (2) climatic events surrounding the cooling of the Antarctic, and (3) the opening of the Drake Passage as important paleoceanographic sets of events. Accordingly (but without prejudging their origins), we refer to reflectors aged 2-4 Ma as "Panama Series," to those aged 10-19 Ma as "Antarctic Series," and to those aged 19-23 Ma as "Drake Series." These ages are approximate: the criterion is grouping, not dating. Roughly, these groups correspond to the Pliocene, the middle Miocene, and the lower Miocene.

The interval between the Panama and Antarctic series is the "Tethys Interval," which contains sediments deposited during mountain building in the closing Tethys belt. This interval includes the entire upper Miocene and the lowermost Pliocene. Below the Drake Series is the "Texas Interval," which is acoustically subdued in Site 805 , but which has two distinct reflector groups in Site 806 . In essence, the Texas Interval brackets the Oligocene. (It is so named to honor Texan drilling know-how.) Below this interval is the "Ontong Java Series," a group of strong reflectors, ubiquitous on the plateau, that derives from impedance changes caused by the formation of limestone and chert in the upper Eocene.

The Panama Series contains the reflectors already discussed for Site 803 ; these can also be identified at Site 586, using the velocity profile provided by Shipboard Scientific Party (1986). The Tethys Interval contains a number of reflectors of lesser strength. Lithification occurs in the upper Miocene at both sites, presumably producing weak reflectors through the alternation of ooze and chalk layers. Throughout this interval, Site 806 has the stronger reflectors. The presumed condensed section near 10 Ma (see "Sedimentation Rate" section, "Site 805 " chapter, this volume) has a less than prominent group of reflectors at the base of the Tethys Interval. In Site 806, again, the equivalent section is more strongly reflecting. In either site, the ooze-chalk transition (as determined visually) does not seem to be strongly expressed.

The next group of strong reflectors (traveling downsection) is the upper part of the Antarctic Series, which is centered on the middle Miocene (13 Ma). The lower part of this series is somewhat weaker and belongs to the lowermost middle Miocene and uppermost lower Miocene (15-18 Ma). This entire zone is characterized by a major climatic change, with associated excursions in carbonate content and other sediment properties (Barron et al., 1985). Presumably, these changes are associated with the onset of AABW production at that time. The group of reflectors immediately below the Antarctic Series, the Drake Series, has the strongest reflectors in both sites. Ages range from about 18.5 Ma for the uppermost part of the group to $22.5 \mathrm{Ma}$ for the deepest.

The Texas Interval is more or less transparent acoustically in Site 805 , suggesting the absence of significant events. However, in Site 806 , the interval has two strong reflector groups. Presumably, the reason for the difference is diagenetic enhancement in Site 806 , providing an augmentation of contrast that is missing in Site 805 . The diagenetic enhancement in Site 806 may result from the presence of more reactive carbonate or from the greater thickness of the sediment, or both. The zone of lithologic uniformity that makes up the Texas Interval also was noted by the Leg 130 biostratigraphers for its paucity of evolutionary events. Below this interval, a group of strong reflectors, the Ontong 


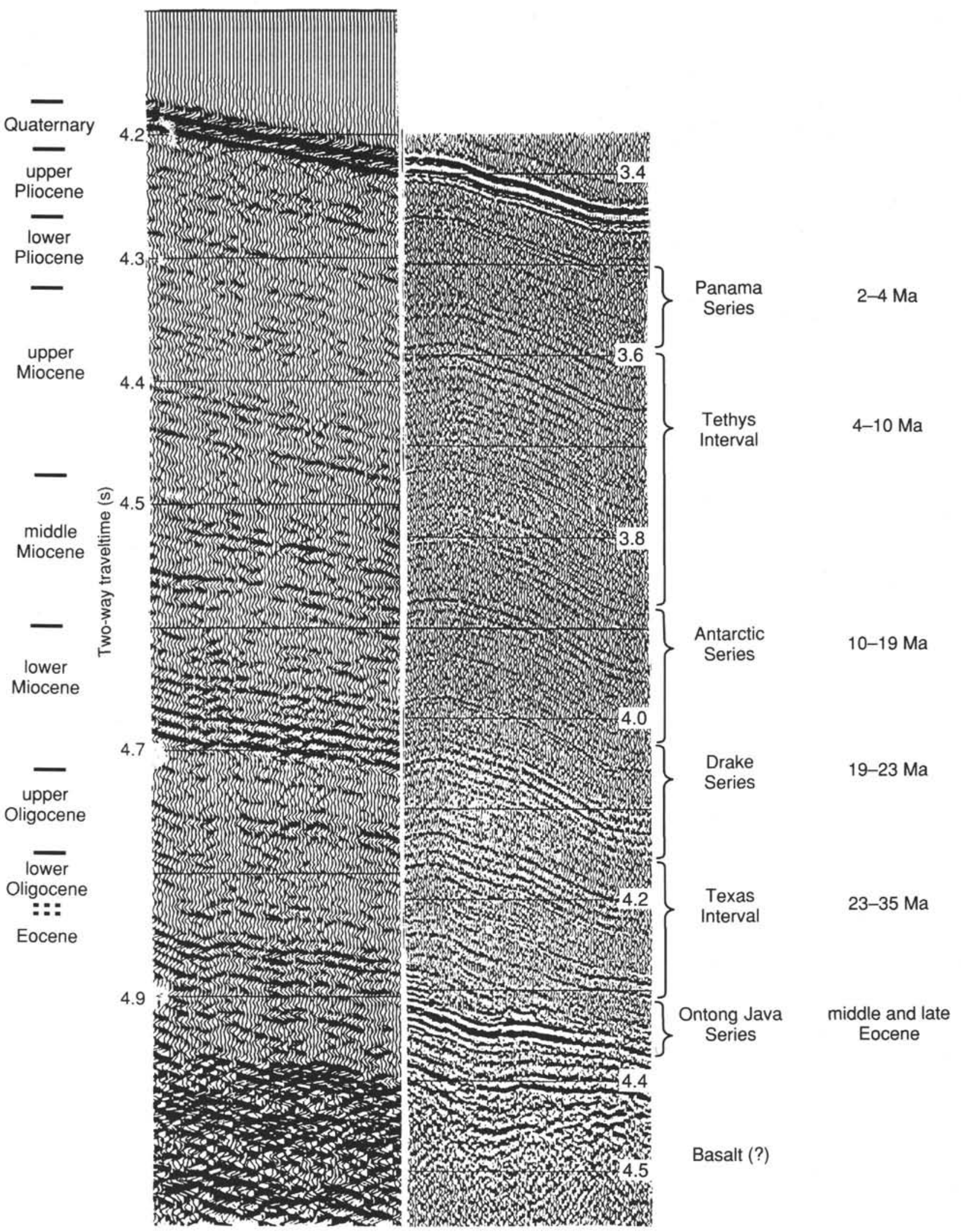

Figure 22. Correlation of seismic reflectors at Sites 805 and 806. Profiles taken by the Thomas Washington on ROUNDABOUT Cruise 11 site survey, with the time scale assigned from drilling and logging results and biostratigraphy. Names to the right refer to groups of reflectors ("series") and to zones with less distinct groups ("intervals"). The record of Site 806 is to the right; its scale was reduced by a factor of 0.73 with respect to that of Site 805 , in order to obtain an approximate match for the reflectors. 
Java Series, is thought to represent the change from chalk to limestone in the lowermost Oligocene, as well as the occurrence of Eocene chert somewhat deeper in the section.

The quality of the match achieved by simple correlation of the reflectors in Sites 805 and 806 is surprisingly good. The positions of the reflectors can be calculated in detail on the basis of velocity profiles (Fig. 23). Tests show that mismatches of correlated reflectors are on the order of $10 \mathrm{~m}$-about the same as the quality of biostratigraphic correlation. For example, a reflector $(0.50 \mathrm{sbsf})$ dated at $22.0 \mathrm{Ma}$ in Site 805 was correlated with a reflector in Site 806 ; its age turned out to be $22.3 \mathrm{Ma}$, $10 \mathrm{~m}$ too deep for a perfect fit. To check this proposition further, specific matches were selected and dated independently. For a perfect match, the dates on the same line should be identical (each comparison shows Site 805 first, then Site 806):

1. $0.044 \mathrm{sbsf}, 35 \mathrm{mbsf}, 1.95 \mathrm{Ma} ; 0.061 \mathrm{sbsf}, 48 \mathrm{mbsf}, 2.05$ $\mathrm{Ma}$;

2. $0.128 \mathrm{sbsf}, 103 \mathrm{mbsf}, 4.44 \mathrm{Ma} ; 0.170 \mathrm{sbsf}, 139 \mathrm{mbsf}, 4.49$ Ma;

3. 0.258 sbsf, $216 \mathrm{mbsf}, 7.17 \mathrm{Ma} ; 0.332 \mathrm{sbsf}, 285 \mathrm{mbsf}, 7.64$ $\mathrm{Ma}$; and

4. 0.363 sbsf, $315 \mathrm{mbsf}, 12.70 \mathrm{Ma} ; 0.480 \mathrm{sbsf}, 435 \mathrm{mbsf}$, $12.34 \mathrm{Ma}$.

The average difference among the age estimates is $0.23 \mathrm{~m} . \mathrm{y}$. for the five determinations, close to the interpolation errors of the biostratigraphic age. Thus, as far as we can tell, the correlative reflectors of Sites 805 and 806 are identical in age.

This demonstration of synchroneity of the reflectors of Sites 805 and 806 is an important result. It provides strong support for the hypothesis that many reflectors represent the effects of paleoceanographic events that are felt over a wide depth range and, hence, are of global significance. Other reflectors may be regionally strong expressions of minor events or may be related to diagenetic processes that are not synchronous.

The fact that reflectors occur in groups suggests that the ocean system, when in transition from one state to another, does so in steps marked by reversals toward the original state or by assuming a sequence of strange states before finding the target state. This is as expected if we are dealing with a chaotic system characterized by quasi-stable substates ("attractors"). Any one set of boundary conditions, governed by geography, will have a set of attractors whose presence is revealed mainly by Milankovitch forcing. Because plate tectonics and volcanism change the boundary conditions, another set of attractors gradually emerges. If the distance between the two sets is great (as when opening or closing a major ocean passage), the system has the opportunity for large-amplitude fluctuations, even though forcing has not changed. At such times, facies changes in any one place also will be large, so that physical properties likewise will fluctuate greatly. This "transitional hypersensitivity" is subsequently recognized as reflector groups, especially after diagenesis has enhanced the signal. If these suggestions have merit, it is immediately obvious why the correlation of reflector groups is a useful approach to acoustic stratigraphy.

\section{PALEOGENE AND CRETACEOUS SEDIMENTS}

\section{Goals and Recovery}

Objectives for the pre-Neogene record centered on improvement of the biostratigraphic record, on diagenesis, on the origin

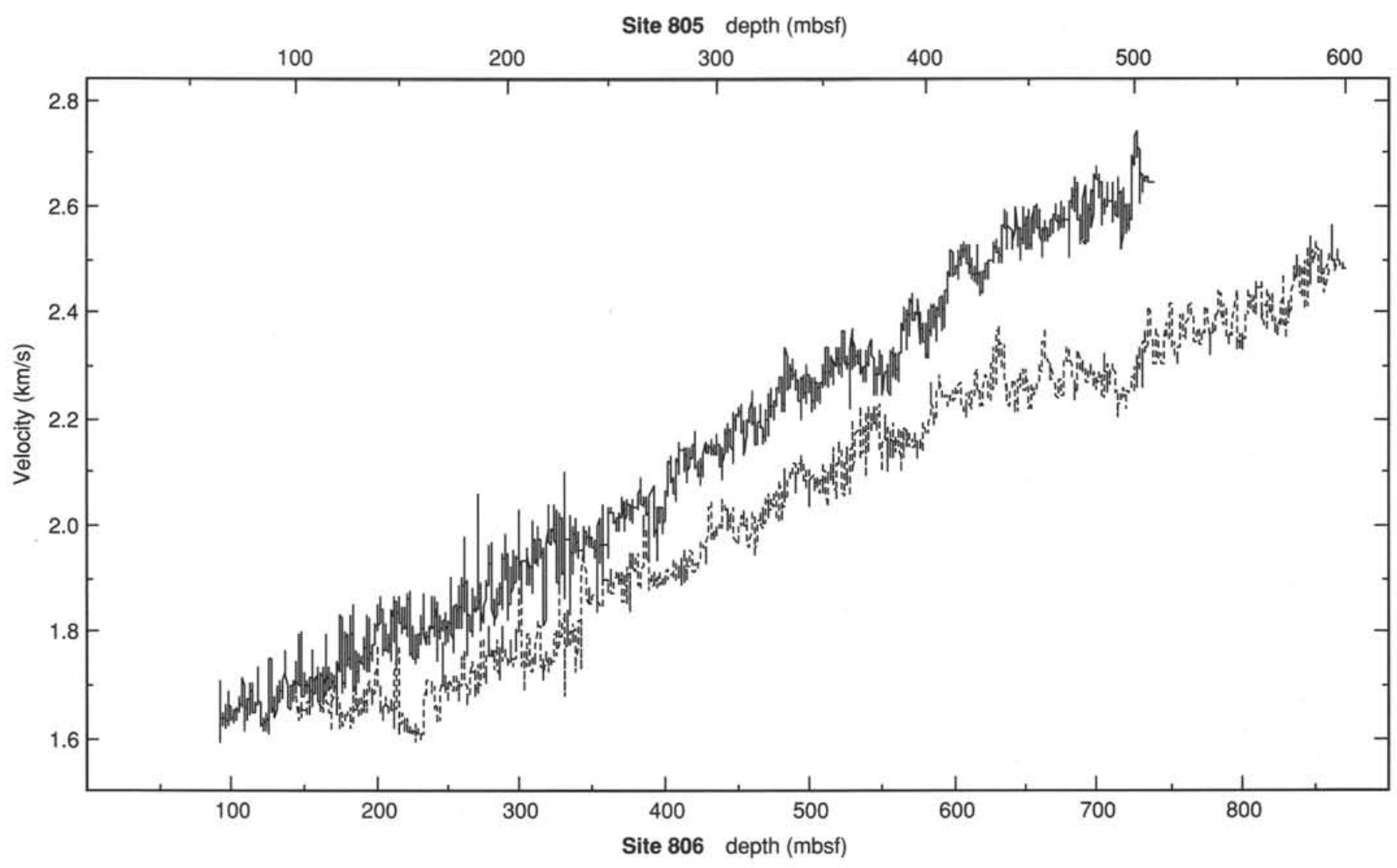

Figure 23. Velocity profiles in Sites 805 (dashed line) and 806 (solid line), plotted to emphasize correlation of fluctuations. Note linear offset of depth axis to aid the graphical comparison. Drawn by M. Lyle. 
of hiatuses, and on the nature and extent of anoxic events in the Pacific. We also hoped to learn more about the Cretaceous/Tertiary boundary. Prospects for complete sections were not good, based on the abundance of substantial hiatuses found in the pre-Oligocene record in DSDP Site 289 (Shipboard Scientific Party, 1975b).

Oligocene material was recovered at all five sites, but pre-Oligocene deposits at the only two ( 803 and 807$)$ that were drilled into basement. In the deeper site $(803,3410 \mathrm{~m})$, hiatus formation was extensive below the middle Eocene. Only short sections of the record were recovered between the Eocene and the Aptian?. Fortuitously, one of these sections contains a complete $\mathrm{K} / \mathrm{T}$ transition in a sub-CCD setting (but with traces of carbonate). In the shallower site $(807,2805 \mathrm{~m})$, the Paleogene is well represented, and there is an apparently complete section for the Maestrichtian. Again, the K/T boundary section is complete (within the biostratigraphic resolution). The record between the Maestrichtian and the Cenomanian is missing, whereas those of the Cenomanian and Albian are poorly represented $(<30 \mathrm{~m})$, considering the length of time involved ( 20 m.y.).

\section{Paleogene Sediments}

Oligocene sediments were penetrated in all sites and were invariably assigned to lithologic Subunit IB, nannofossil chalk. Overall sedimentation rates can be determined in Sites 803 and 807 , where they are 18 and $25 \mathrm{~m} / \mathrm{m} . \mathrm{y}$., respectively. The latter value is low because of a mid-Oligocene hiatus (Fig. 4). If these rates are corrected for compaction, they are fully equivalent to average Neogene sedimentation rates. Peak rates also are of comparable magnitude. The transition from the late Oligocene to the early Miocene is uneventful; in fact, it is so gradual that considerable difficulties were encountered when identifying the boundary.

Oligocene sediments are homogeneous and have uniformly high carbonate values. In regions near the lysocline, the differences in diagenetic potential (Schlanger and Douglas, 1974) may be low, judging from the weakness of reflectors (Texas Interval at Site 805 and at deeper sites). Farther upslope, differential diagenetic processes (incipient limestone and chert formation) apparently enhance subtle lithologic contrasts, greatly increasing the echo potential. In essence, the formation of limestone and chert is a recrystallization process that feeds on fossils. Preservation of both nannofossils and diatoms deteriorates, therefore, as diagenesis proceeds (and the echo potential rises).

Eocene sediments, in contrast to those of the Oligocene, exhibit great diversity of lithology. The late Eocene record is not much different from that of the early Oligocene, except for somewhat increased lithification. This was included in the nannofossil chalk unit that spans the last $40 \mathrm{~m}$.y. However, siliceous material became much more important before that time, and the rest of the Eocene record is characterized by interbedded radiolarian-bearing chalks, calcareous radiolarites, and various types of limestones and chert. These deposits are readily seen as strong reflectors over broad reaches of the plateau.

The top of these reflectors (the Ontong Java Series) marks a major reorganization of the silica budget of the ocean. This reorganization traces out a transition from global silica glut to global silica starvation at about $40 \mathrm{Ma}$. On the whole, this starvation has prevailed since. Silica starvation may be caused by a general lack of supply to the ocean or to localized excess consumption. To call on increased silica supply in the Eocene, one can point to the evidence for increased volcanism (Kennett et al., 1977) and to increased chemical leaching of continental bedrock during a warm climate with low-lying continents (van Houten, 1982). To find excess consumption during post-Eocene time, one would have to look to the Antarctic Ocean and to the ocean margins. The fact that the ocean acquired cold, deep waters at about $40 \mathrm{Ma}$ (Shackleton and Kennett, 1974) shows that a strong increase in the planetary temperature gradient occurred, which inevitably resulted in upwelling (and in silica removal) in high latitudes and along the ocean margins.

High, scattered concentrations of silica in the pelagic sediments of the Eocene ocean may have been produced, in part, by episodic carbonate buildup on widespread Eocene shelf seas, which would have removed the major dilutant. Occasional global nitrate deficiency, the result of denitrification in a warm, lowoxygen ocean, would have increased concentrations of silica in the water by decreasing the removal of silica by diatoms, which would have needed this nitrate for growth (Berger and Roth, 1975).

The striking difference in sectional preservation between postEocene and pre-Oligocene deposits may be related to the overall change in silica content. In the sections we drilled (803 and 807), hiatuses and condensed sections were common throughout $\mathrm{Pa}$ leocene to middle Eocene time, and similar observations have been made elsewhere on the plateau. We postulate that the presence of silica-rich layers in the older Paleogene sediments led to early lithification within selected beds, impeding dewatering of the formations. When earthquakes shook the plateau (e.g., as a consequence of its collision with the Melanesian subduction system), high interstitial water pressures below semilithified beds facilitated wholesale removal of extensive sediment blocks by mass wasting. In contrast, when silica starvation set in, bedding became much less pronounced, and lithification increased cohesion in a three-dimensional framework without impeding dewatering. Thus, the sediment stack became much more stable. Earthquakes then mainly affected sediments on the steeper slopes, at the lower flanks of the plateau. Farther up toward the top of the plateau, shaking resulted in dewatering, rather than in sliding.

The silica hypothesis of sectional preservation may be generalized to a bedding-plane hypothesis: when bedding is strong, removal is more likely. If so, horizons having strong acoustic reflectors are more likely to harbor hiatuses (which in turn enhance the echo potential). The hypothesis (involving either silica or carbonate removal) also offers an explanation for the observation that reorganization of the system can produce hiatuses: during such transitions, bedding develops because the system jumps back and forth between climatic states. In turn, bedding increases the sensitivity to mass movement during earthquakes by hindering dewatering.

\section{Cretaceous/Tertiary Transition}

Given that the pre-Oligocene record on the Ontong Java Plateau is riddled with hiatuses, as seen at Sites 64 and 289 and on seismic profiles, we hardly expected to recover a complete section across the $\mathrm{K} / \mathrm{T}$ boundary. In fact, we recovered not one, but two such sections, one each from the two holes that penetrated into the Cretaceous.

At Site 803 , the K/T boundary occurs near 622.3 mbsf within dark brown claystone (in part silty) with signs of reworking (Fig. 24). The section has a low carbonate content and some poorly preserved radiolarian remains. The depth of deposition, assuming isostatic adjustment of the basement under the increasing sediment load, would have been somewhere near $3.5 \mathrm{~km}$. At Site 807 , the boundary is near $1193.1 \mathrm{mbsf}$, within white to gray limestone with variable amounts of silica cement. Lithified volcanic ash is associated with the boundary (Fig. 24). The depth of deposition, assuming isostatic adjustment, would have been near $3 \mathrm{~km}$, considering that a graben was still forming at the time of deposition of lower Tertiary sediments. Thus, the most probable depth for the CCD during the time of the $\mathrm{K} / \mathrm{T}$ transition would have been somewhere between 3 and $3.5 \mathrm{~km}$.

The lithologic change across the $\mathrm{K} / \mathrm{T}$ boundary at Site 803 is unremarkable, with traces of carbonate, chert fragments, and glass present in smear slides above and below. There is a trend 

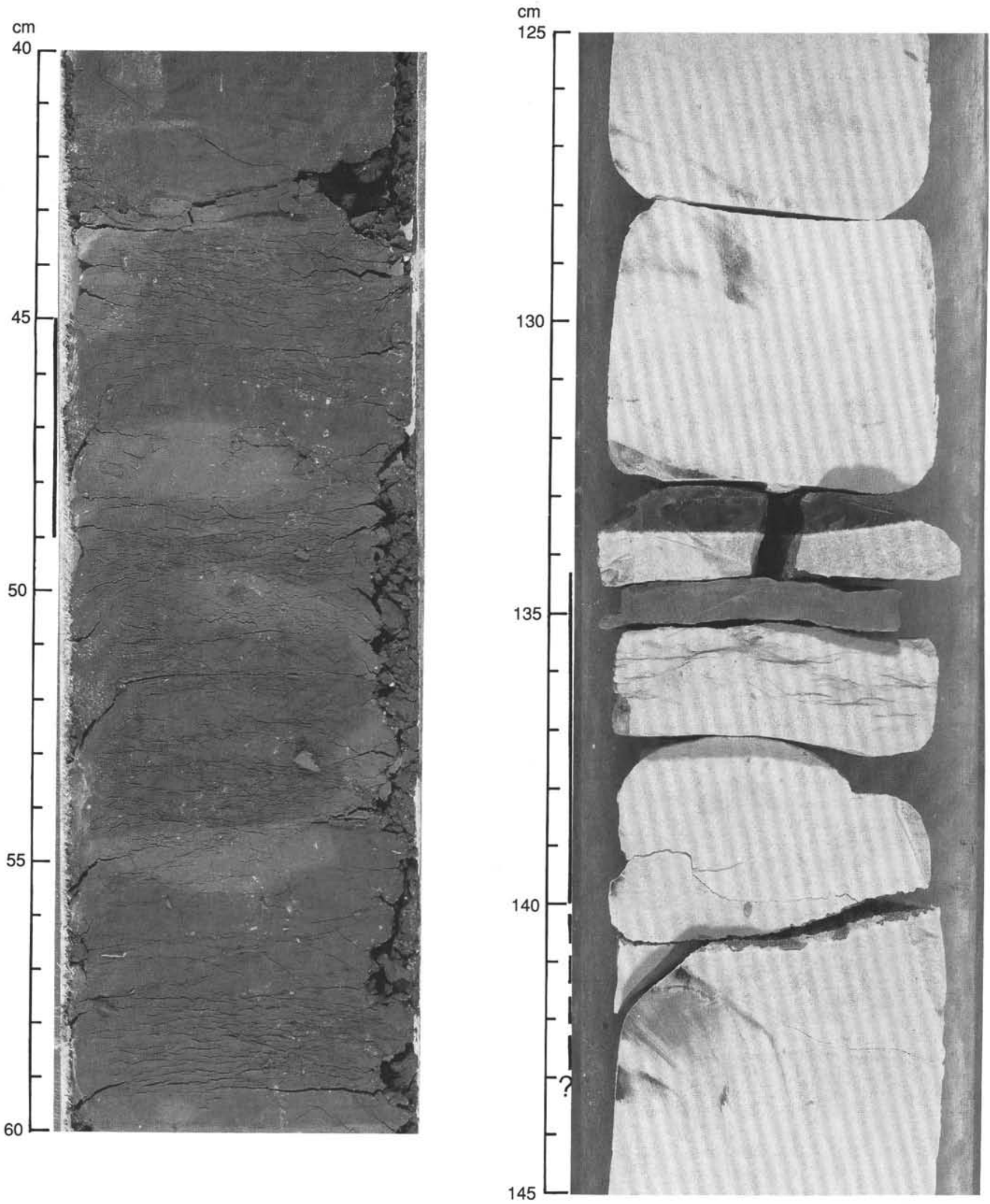

Figure 24. Cretaceous-Tertiary transitions at Sites 803 (Interval 130-803-68R-1, 40-60 cm; left) and 807 (Interval 130-807C-54R-3, 125-145 cm; right). The first is noncalcareous; the second occurs within limestone. Note the presence of lithified volcanic ash at Site 807. Cretaceous/Tertiary boundary intervals are indicated by a bar on each figure. 
toward increasing carbonate on approaching the boundary (i.e., the CCD moves to greater depth), and a distinct jump in carbonate content coincides with the appearance of Thoracosphaera. Above this jump, carbonate content fluctuates, and radiolarian remains (and glass) appear better preserved than below the jump.

The position of the $\mathrm{K} / \mathrm{T}$ boundary was identified by means of calcareous nannofossils from a poorly preserved and low-diversity assemblage (see "Biostratigraphy" section, "Site 803 " chapter, this volume). The criterion used to place the boundary was the appearance of Thoracosphaera, a dinoflagellate cyst presumably indicating conditions of stress. Also at that level, Cretaceous nannofossil species, including Micula prinsii, decrease in abundance drastically. The presence of Micula prinsii signals that the latest Maestrichtian was indeed recovered (Monechi, 1985). The presence of Markalius astroporus and that of Biantholithus sparsus indicate that basal Danian material was recovered. Reworked Cretaceous species also are common in the basal Danian section.

The lithologic change across the boundary at Site 807 also is unremarkable, except for the ash layer associated with the boundary (Fig. 24). The limestone above and below is moderately to highly bioturbated with millimeter- to centimeter-scale, subhorizontal, compacted burrow traces. Submillimeter-scale flaser structures are common. Below the boundary, faint, light grayish bands and stylolites can be seen. Dark reddish gray chert is present throughout as fragments of continuous layers up to $6 \mathrm{~cm}$ thick and as irregularly shaped masses in limestone pieces.

On the basis of nannofossils, the $\mathrm{K} / \mathrm{T}$ boundary was placed (see "Biostratigraphy" section, "Site 807 " chapter, this volume) within a 16-cm interval at the base of Section 130-807C-54R-3. The first appearance, rapid rise in abundance, and subsequent decline of Thoracosphaera are the chief criteria. Within this boundary interval, Thoracosphaera is rare, but it is abundant immediately afterward. Cretaceous forms are common throughout the section, from uppermost Maestrichtian to lowermost Danian. In fact, they increase again in abundance after a decline within the vicinity of the boundary itself. Thus, reworking across the boundary is indicated, as well as an increase in preservation, which allowed the reworked material (from upslope) to remain abundant. In contrast, the Tertiary forms are present in subdued numbers, having been delivered from surface production, rather than from downslope reworking, and being more susceptible to dissolution as well.

At Site 807 as at Site 803 , a decline of the CCD across the transition is indicated, perhaps by roughly $200 \mathrm{~m}$. The presence of uppermost Maestrichtian is documented by Micula prinsii, which is present in a sample taken just about $1 \mathrm{~m}$ below the boundary. From about $1 \mathrm{~m}$ above the boundary upward, trace amounts of Danian placoliths (Biscutum, Cruciplacolithus, and Toweis) are present.

In sum, the great change in the nannofossil flora, described by Bramlette (1965) and many since, is represented in both sections, although in a condition of poor fossil preservation. The sudden disappearance of a rich nannofossil flora, and the appearance of abundant Thoracosphaera, has been extensively commented on. In our samples, it appears that Thoracosphaera is abundant because it was resistant to dissolution. Its dominance may owe more to the fact that nannofossils were no longer available for delivery to the seafloor. Thus, the commonly used term "bloom" for these mass occurrences may be misleading: even if production of Thoracosphaera was low, it would show the dominance pattern seen in the absence of a viable nannoflora. An interpretation that Thoracosphaera represents stressful conditions after the $\mathrm{K} / \mathrm{T}$ event, while appealing, cannot be based on these observations. For all we know, conditions may have been excellent for the growth of Cretaceous nannofossils. However, they were no longer around to take advantage of any such opportunity.
The $\mathrm{K} / \mathrm{T}$ boundary at Site 807 is embedded in a limestone sequence that does not seem to have major hiatuses in the immediate vicinity of the transition, although the poor preservation of nannofossils and low sedimentation rates indicate a position near the CCD of the time. In contrast, the $\mathrm{K} / \mathrm{T}$ boundary at Site 803 is uniquely situated between major hiatuses and greatly condensed sections. The a priori probability of finding any particular section of $100,000-200,000 \mathrm{yr}$ in this great record void cannot be estimated. Given that one such preserved layer is present, the probability that it contains the K/T boundary would be on the order of 1 in 1000 . Thus, our finding the K/T boundary must be ascribed either to incredible luck or to a process that made the sedimentary record of this particular time interval unusually preservable.

We suggest that a case can be made for preservation-enhancing circumstances at the $\mathrm{K} / \mathrm{T}$ boundary at this sub-CCD level. Two conditions had to be fulfilled. First, the site had to be close enough to the CCD to preserve enough nannofossils for identification. This was a matter of luck-at a greater depth, we might have recovered the $\mathrm{K} / \mathrm{T}$ boundary without realizing it. Second, the deposited material had to be cemented early, so that it was not removed during erosion episodes. We assume that such quasi-contemporaneous episodes are responsible for the removal of extensive sequences in the Late Cretaceous and early Tertiary in this setting.

We think that the early cementation was accomplished by silica supersaturation and possibly by increased metal precipitation (iron and manganese). The mechanism we postulate is simple: when biological activity was greatly reduced at the end of the Cretaceous by making the ocean unsuitable for pelagic plankton, the ocean tended to revert to its thermodynamic state. In this state, saturation with silicate was achieved in the deep sea, and supersaturation thus could be achieved in interstitial waters. Early cementation by silicification was then possible. Volcanism, indicated by the ash layer in Site 807 , may have been a contributing factor by releasing silica and metals to deep waters. In favor of the silica-enrichment hypothesis, note that some evidence exists for enhanced preservation of radiolarians. Early cementation also would have trapped metals that could have added to the erosional resistance.

There is evidence from magnetic studies for iron enrichment exactly at the boundary: a strong peak in magnetic susceptibility in Section 130-803D-68R-1, at $45 \mathrm{~cm}$. The presence of magnetic spherules may be responsible (see "Site 803 " chapter, "Paleomagnetics" section, this volume). The high background and an additional spike deeper in the section suggest generally increased iron flux to the seafloor, supporting the suggestion regarding increased volcanic activity.

The evidence for volcanism in Site 807 , in the form of lithified ash associated with the boundary, is of some interest, considering the possible role of volcanism in changing the Earth's habitability during K/T time (e.g., McLean, 1985). The deeper site exhibits evidence of volcanic activity throughout, not just right at the boundary. Presumably, if Earth was hit by a bolide during the event (Alvarez et al., 1980), volcanism would surely have been stimulated. Thus, there is no point in entering a debate that poses the question in terms of bolide vs. volcanism. In any case, without chemical and petrological studies, a plain mid-ocean origin for the volcanism observed cannot be excluded and, indeed, remains an attractive possibility. After all, the plateau is of volcanic origin, and the record shows evidence for volcanic activity well into the Paleogene.

\section{Cretaceous Sediments}

The contrast between the two sites that have Cretaceous sediments is surprising, considering the moderate difference in depth of deposition that apparently prevailed at the time: on the order of $500 \mathrm{~m}$ (see above). If dissolution below the CCD was the 
cause for the difference in sediment accumulation, the dissolution gradient across this depth must have been strong, which has implications for global ocean productivity. There is no need to dissolve and recycle carbonate in a stagnant ocean, and dissolution gradients should be weak, were productivity low. Contrasting carbonate contents across moderate depth differences indicate conditions that, if widespread, should disagree with the ocean-desert hypothesis of Bralower and Thierstein (1984).

The deeper site contains less than $4 \mathrm{~m}$ of the Cretaceous section, all of which is noncalcareous, dark brown claystone. This material represents the entire time span between the $\mathrm{K} / \mathrm{T}$ boundary and the top of the last basalt, about $40 \mathrm{~m} . \mathrm{y}$. Within the last core section above the basalt, there are several centimeter-thick layers of soft, dark, yellowish brown radiolarite (Fig. 25). These layers contain radiolarians of late Albian to early Cenomanian age. The shallower site has $186 \mathrm{~m}$ of limestones and claystones, representing mainly the Maestrichtian (limestones) and the Cenomanian and Albian (claystone and limestones). A hiatus spanning up to $20 \mathrm{~m} . \mathrm{y}$. between these periods apparently is indicated. Sedimentation rates in the Maestrichtian are high (about $20 \mathrm{~m} / \mathrm{m}$.y.), which corresponds to accumulation rates comparable with those in the late Neogene.

Why was sectional preservation 40 times better at Site 807 than at Site 803 ? Was it because carbonate sedimentation at the shallower site allowed for earlier lithification? Was it the result of local tectonic effects? With the small number of sites available, and in the absence of mapping of Cretaceous sections by seismic methods, we were unable to address these questions. Reworked clasts containing older fossils are present in lower Tertiary rocks at Site 807, as well as in Cretaceous rocks (Fig. 25). This indicates the effects of erosion from the rims of the graben, the formation of which preserved the sequence we found.

The upper Albian and lower Cenomanian claystone with radiolarians, found at Sites 803 and 807 , suggests that the CCD stood high at that time, possibly as high as or higher than $3 \mathrm{~km}$ (cf. Thierstein, 1979) (Fig. 26). Limestone remains are associated with the basaltic basement at both sites, indicating a lower $\mathrm{CCD}$ (or a higher plateau) during the time of the last lava flows, in late Aptian(?), or in Albian time. There is no indication of

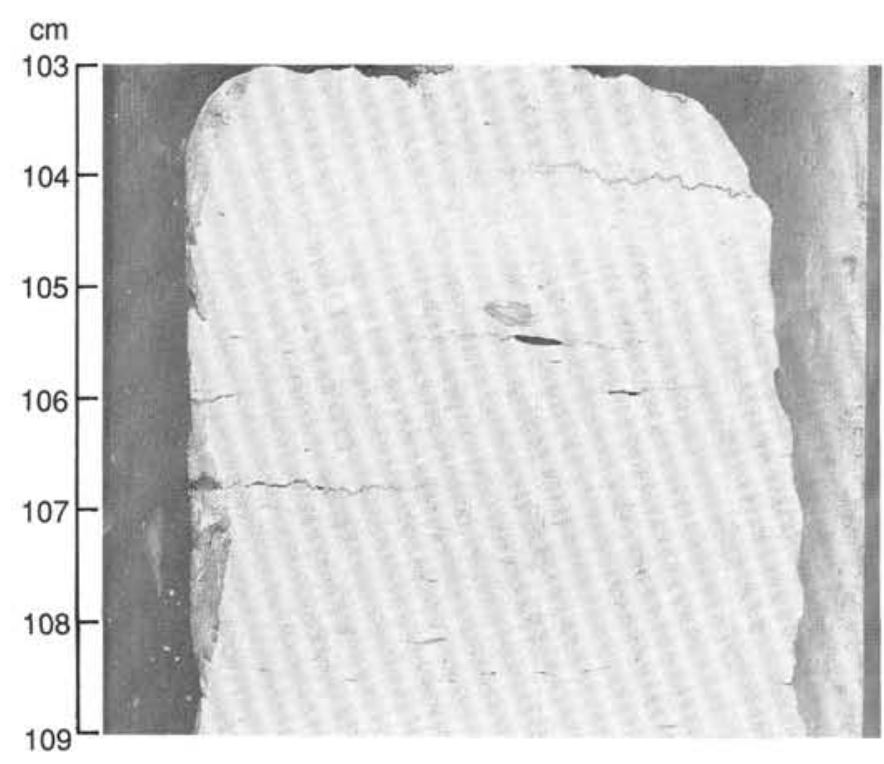

Figure 25. Upper Campanian to lower Maestrichtian limestone, with limestone clasts presumably derived from the erosion of the graben rim and redeposition within the graben at Site 807 (Interval 130-807C-65R-2, 103-109 cm). anoxic events, although their presence cannot be excluded because of the spotty record.

\section{BASEMENT DRILLING RESULTS}

\section{Objectives and Setting}

The main goals for drilling into basement concerned the question of the origin of Ontong Java Plateau (the world's largest oceanic plateau) and the origin of oceanic plateaus in general. When was the basalt emplaced? At what rate? What was its source? These are questions that can only be solved when sufficient material has been recovered. The significance of oceanic plateaus in general, inter alia, pertains to their possible role in the growth of continents (Kroenke, 1974; Storey et al., in press).

The Ontong Java Plateau, with an areal extent of roughly 1 million $\mathrm{km}^{2}$ (the same as Spain and France combined), is more than twice the size of the next largest flood basalt province, the Deccan Traps. The enormous outpourings of basalt during the middle Cretaceous, which appear to be indicated by our results, should have raised the sea level and, if sufficiently concentrated in time, may have affected the circulation and chemistry of the ocean and, therefore, also the chemistry of the atmosphere, producing large-scale climatic warming (see Arthur et al., 1985). A volume of more than 25 million $\mathrm{km}^{3}$ of basaltic crust may be estimated for Ontong Java Plateau, based on seismic refraction data (roughly the same as the volume of ice on Antarctica). Rapid emplacement of this basalt, without isostatic adjustment, might have raised the sea level by more than $50 \mathrm{~m}$.

\section{Recovery and Rock Types}

So far, penetration into basement of Pacific plateaus has been moderate (Fig. 27). Thus, the two sites of Leg 130 at which basalt was recovered provide a substantial increase in material for attacking questions regarding the origin of plateau basalts. The Leg 130 scientists recovered $11 \mathrm{~m}$ of basalt at Site 803 and $92 \mathrm{~m}$ at Site 807.

Basalts at both sites are tholeiites. At Site 803, the rocks mainly consist of successive pillow lavas, whereas at Site 807, both pillow and massive lavas occur, the latter mostly less than $3 \mathrm{~m}$ thick, but including one 28-m-thick flow (Fig. 28). In places, sedimentary layers occur between flows. Calcareous fossils are present, but they have been recrystallized beyond specific recognition. Basalts are nonvesicular, hypocrystalline, fine grained, and aphyric to sparsely phyric. At Site 803 , alteration ranges from severe to moderate within pillow interiors, whereas at Site 807 , alteration rarely exceeds a moderate level and is restricted to the vicinity of veins, presumably marking ducts for hydrothermal fluids from greater depths.

\section{Petrography and Chemical Properties}

Thin-section examination of pillow interiors confirmed the fine-grained, typically aphyric, hypocrystalline nature of the basalt. Phenocrysts observed include rare subhedral $(<0.5 \mathrm{~mm})$ pseudomorphs of olivine, zoned clinopyroxene, and plagioclase laths. The deeper units at Site 807 also contain altered olivine microphenocrysts. The most noteworthy petrographic aspect of these rocks, however, is the scarcity of phenocrysts. In the lower $103 \mathrm{~m}$ of the basement sequence at Site 807 , these are essentially absent.

Major and trace elements on pillow interiors were determined by X-ray fluorescence spectrometry on board the ship for Site 803. For Site 807 , analyses were performed at the University of Keele. At Site 803 , the basalts are fairly evolved $(\mathrm{Mg} \#=35-53)$, mildly quartz- to olivine-normative tholeiites. These basalts have MORB-type $\mathrm{Ti} / \mathrm{Zr}$ and $\mathrm{Zr} / \mathrm{Y}$ ratios and high $\mathrm{Sr}, \mathrm{Ca}$, and $\mathrm{K}$ concentrations. $\mathrm{Zr} / \mathrm{Nb}$ ratios are distinctly low compared with nor- 
$\mathrm{cm}$
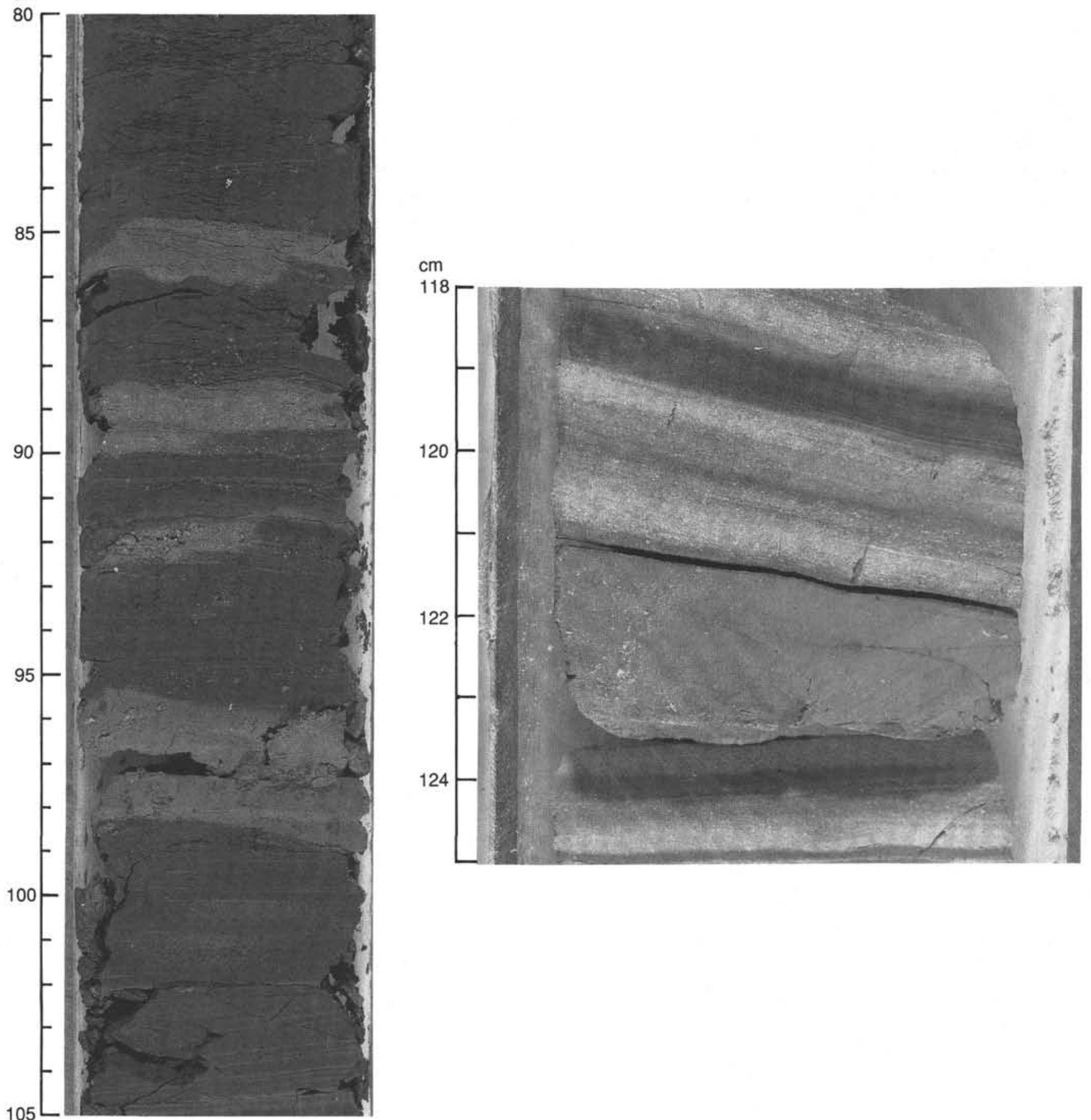

Figure 26. Barren dark brown claystones with lighter colored radiolarian-rich layers. Radiolarians indicate an age of late Albian to early Cenomanian. Left: Site 803 (Interval 130-803D-68X-3, 80-105 cm); right: Site 807 (Interval 130-807C-72R-1, 118-125 cm).

mal MORBs, as are $\mathrm{Ti}, \mathrm{Zr}$, and $\mathrm{Y}$ abundances, for the level of differentiation indicated by the $\mathrm{Mg \#}$. Thus, these rocks are distinct from normal MORBs. They also are distinct from typical oceanic-island tholeiites by being much less enriched in immobile incompatible elements, such as $\mathrm{Zr}, \mathrm{Nb}$, and $\mathrm{Ti}$, and by having higher $\mathrm{Zr} / \mathrm{Y}$ and much lower $\mathrm{Zr} / \mathrm{Nb}$ ratios (Fig. 29). The closest resemblance is to the few available basalts from other Pacific plateaus, in particular those of the Manihiki Plateau (Jackson et al., 1976) and the rocks recovered at Site 289, not far away (Stoeser, 1975).
In general, the major and compatible trace elements do not display simple inter-element relationships, suggesting that the rocks may represent more than one liquid line of descent or parental magma. In conjunction with $\mathrm{Nd}$ and $\mathrm{Sr}$ isotopic studies, the type of chemical signature found in these rocks has been interpreted to reflect mantle sources that are a combination of MORB- and oceanic-island-type components (Mahoney, 1987).

At Site 807, the plagioclase basalts of the uppermost subunit are enriched in $\mathrm{Sr}, \mathrm{Ti}$, and $\mathrm{Zr}$, making them distinct from those of the lower subunits, which are depleted in these elements. The 


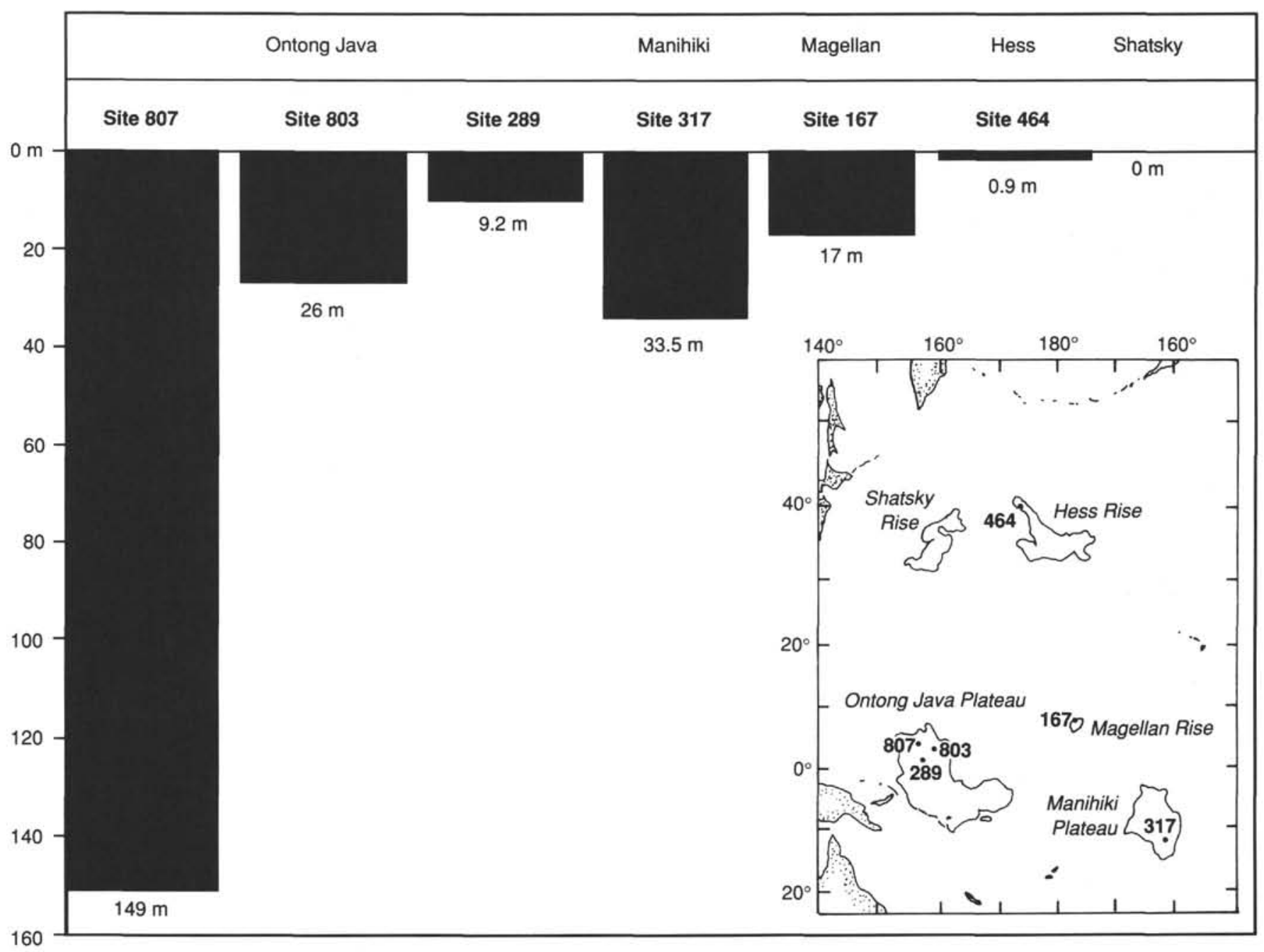

Figure 27. Basement penetration of oceanic plateau basalts in the Pacific.

mineralogical and chemical differences observed for the last and next-to-last lava flows and the limestone layer between them ( $>0.6 \mathrm{~m}$ thick) suggest the passage of considerable time before the last eruption. There is no evidence for similar separation of earlier flows.

Basalts at Site 807 are distinct from those at Site 803. Chemical variations within subunits at Site 807 generally are smaller than those within the unit sampled at Site 803 . In addition, the variations between the older flows at Site 807 (below the limestone layer) are limited, as illustrated in the $\mathrm{Zr}$ vs. $\mathrm{TiO}_{2}$ field (Fig. 30). Note that the basalt at Site 803 occupies a position between the uppermost flow in Site 807 and the flows below the limestone layer at Site 807. The same is true for the Sr data (see "Site 807 " chapter, "Igneous Petrology" section, this volume).

\section{Preliminary Conclusions}

Several eruptions are represented in Site 803. All basalts are moderately differentiated tholeiites that may have been derived from more than one parental magma. The thin, pillowed nature of the flows suggests that their feeder vents were not distant and that eruption rates were low. This feature may be related to the location of this site on the flank of the plateau. In contrast, the thick basalt unit at Site 807 provides clear evidence for the presence of massive flows on the Ontong Java Plateau that are comparable with those of major continental flood basalt provinces.
The general absence of large phenocrysts also is reminiscent of some continental flood basalts.

The flows at Site 807 generally are thicker than those at Site 803 ( $3 \mathrm{~m}$ vs. $<1 \mathrm{~m}$ ); their sparse but ubiquitous olivine microphenocrysts indicate that the lavas at Site 807 may be primitive in composition. The absence of much alteration and of sedimentary interbeds in the deeper portion of the recovered section suggests emplacement over a short period of time, so that any one flow was exposed to seawater only a short time. The uppermost unit at Site 807 apparently was emplaced after passage of considerable time, as indicated by both mineralogical and chemical differences and the presence of a 0.6 -m-thick limestone layer at its base.

The late Aptian to Albian age of the upper basement at the sites where basalt was recovered (DSDP Site 289 and ODP Sites 803 and 807 ) suggests that volcanism was widespread across the Ontong Java Plateau during that time. This final phase of flood basalt effusion was characterized by the eruption of massive flows, interspersed with and followed by the eruption of a series of thin, pillowed flows. The last flows that occurred are scattered after quiescence (as shown by the sediment layers between the pillow lavas), and these late-stage eruptions have a more evolved composition, as seen in the phenocryst assemblage. The first sediments to accumulate on the thermally elevated plateau were deep-water limestones and vitric tuffs that were deposited 


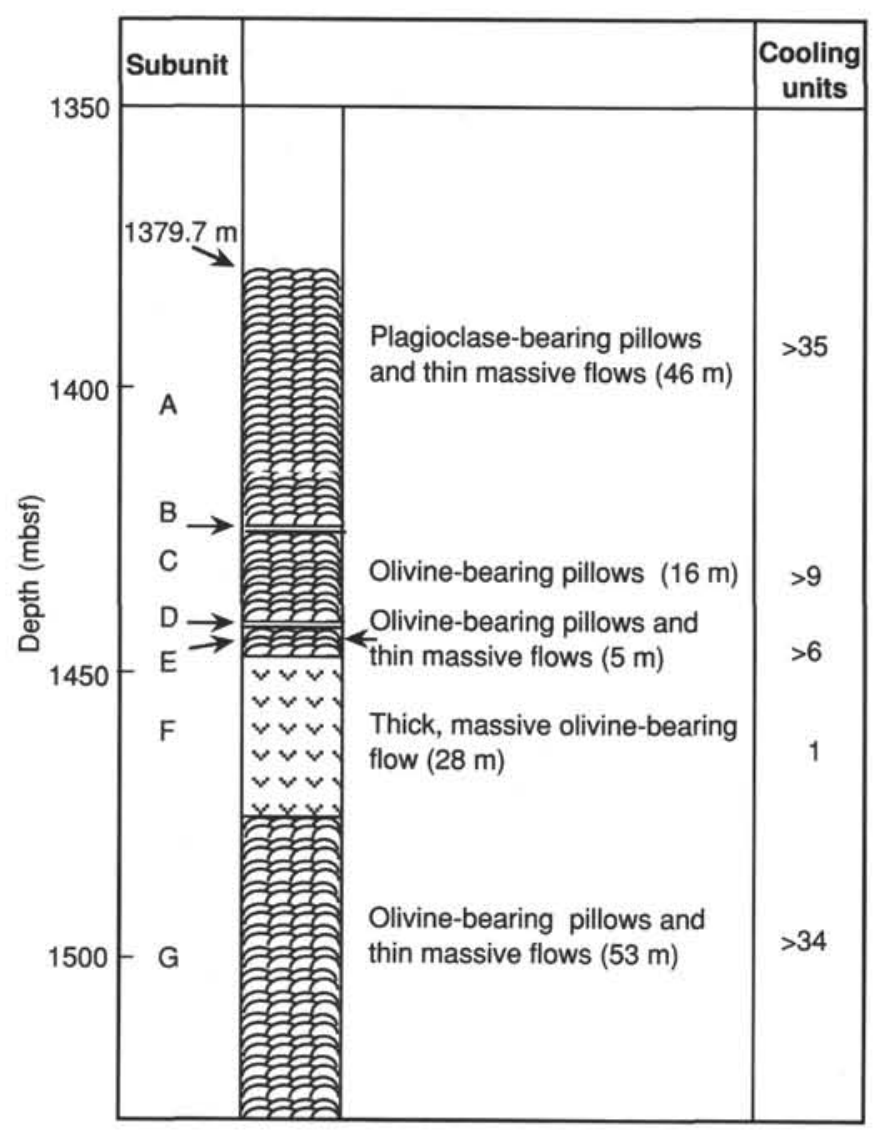

Figure 28. Lithologic column of basement drilled in Hole 807C, showing distribution of pillows and thin, massive flows (A, C, E, G); a thick, massive flow (F), as well as two thin sedimentary interbeds (B, D). Cooling "units" are estimated from glassy chilled rinds and are given on the right for each subunit. Figure by J. Mahoney and M. Storey.

above, but probably near, the Early Cretaceous CCD (25003000 mbsl).

Paleolatitudes from magnetic inclinations in the basalt suggest that Ontong Java Plateau moved coherently with the Pacific Plate because its construction was completed in the Early Cretaceous.

\section{SPECIAL STUDIES}

\section{Paleomagnetism}

Pass-through cryogenic magnetometer measurements were performed for selected APC split-core archive sections, XCB cores, and RCB cores where available, the choice being dictated by the quality of the material. In-situ orientations were attempted in cores where this was deemed profitable. Although the attempt was not always successful, the majority of APC cores that yielded directional data are oriented.

A conspicuous characteristic of the pass-through magnetometer measurements on APC cores was an anomalously high magnetic intensity in the top $50-100 \mathrm{~cm}$ of the first section of each core, signifying physical disturbance through "draw-in" caused by the hydraulic coring process. Despite this problem, APC cores yielded correlatable reversal boundaries at Sites 803,804 , 805 , and 807 . No reversal could be identified in Site 806 . The high-resolution records in the various sites deteriorate rapidly below a sub-bottom depth of between 15 and $50 \mathrm{~m}$, with the ex-

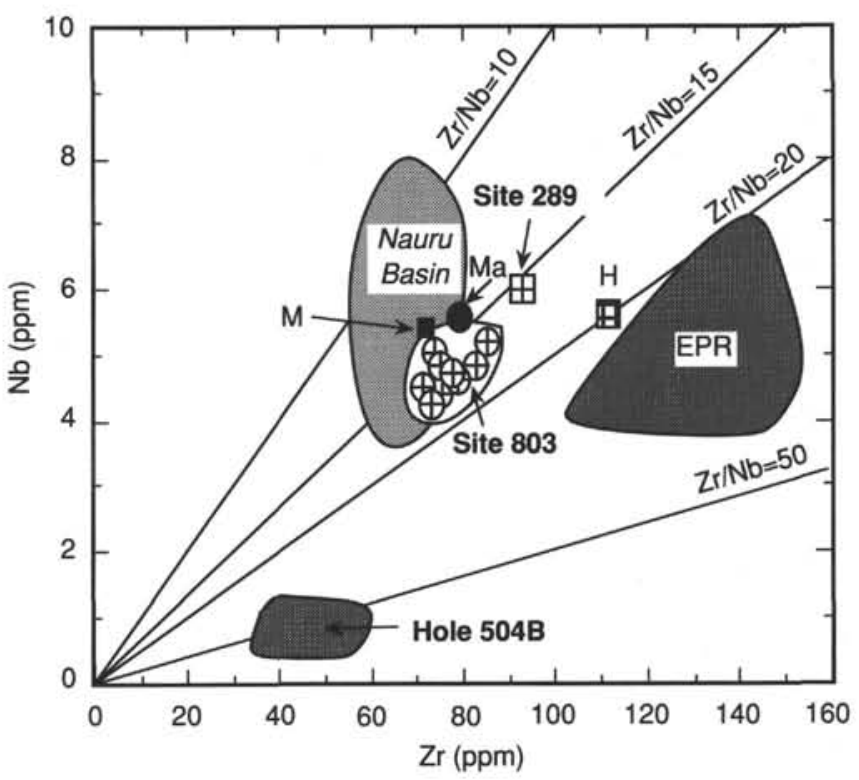

Figure 29. Plot of $\mathrm{Zr}$ vs. $\mathrm{Nb}$ for Site 803 tholeiites. For comparison, fields are shown for the East Pacific Rise ("EPR"), Hole 504B on the Costa Rica Rift, and the Nauru Basin. Averages for Manihiki Plateau lavas ("M") and Malaita basement basalts ("Ma") are also plotted, as are data for the single basalt flows recovered at Site 289 and on Hess Rise ("H"). Plotted by J. Mahoney and M. Storey.

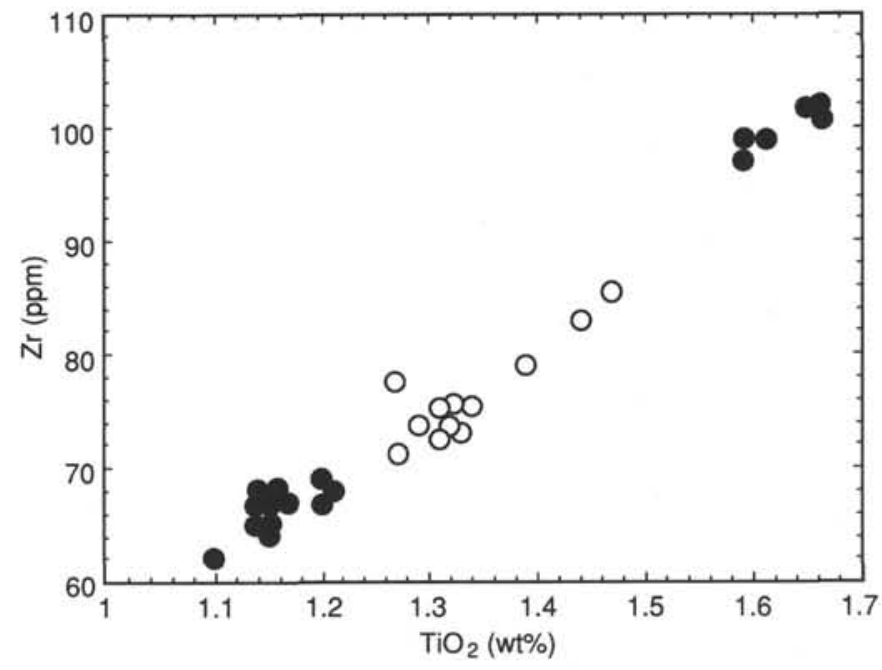

Figure 30. Composition of lava flows, Sites 803 (open circles) and 807 (closed circles), $\mathrm{Zr}$ vs. $\mathrm{TiO}_{2}$. Plotted by J. Mahoney and M. Storey.

act level depending on the site and with Site 806 presenting the worst case.

The level at which the intensity decreases below $0.3 \mathrm{~mA} / \mathrm{m}$ and approaches $0.1 \mathrm{~mA} / \mathrm{m}$ commonly marks the depth interval below which the directional data are uninterpretable. Because of the proximity to the equator, inclinations could not be used to place reversals in the Pliocene-Pleistocene sediments. Changes in the polarity of declination were used instead.

Results for Neogene sediments are summarized in Table 4. A distinct trend can be seen in these data, such that shallower sites and those nearer the equator show deterioration of the magnetic signals at a lesser age of sediment. Two factors combine to re- 
Table 4. Depth of deterioration of magnetic signal, age at that level, and sedimentation rates for selected intervals.

\begin{tabular}{lccccccc}
\hline & \multirow{2}{*}{$\begin{array}{c}\text { Level of } \\
\text { deterioration } \\
\text { Site }\end{array}$} & $\begin{array}{c}\text { Age at } \\
\text { level }\end{array}$ & \multicolumn{4}{c}{ Sedimentation rates (m/m.y.) } \\
\cline { 6 - 8 } & $(\mathrm{m})$ & $(\mathrm{Ma})$ & & Brun & M/B-Old. & Old.-M/G & Gauss \\
\hline 803 & 49 & 4.0 & 10 & 10 & 15 & 15 \\
804 & 47 & 4.3 & 10 & 10 & 12 & 12 \\
805 & 33 & 1.9 & 17 & 17 & - & - \\
806 & 16 & $(0.7)$ & $(20-23)$ & (no reversal determined) & \\
807 & 32 & 2.0 & 16 & 16 & - & - \\
\hline
\end{tabular}

Notes: Intervals are: Brun, 0-0.73 Ma; M/B-Old. = Brunhes/Matuyama boundary to Olduvai, $0.73-1.66 \mathrm{Ma}$; Old.-M/G = Olduvai to Matuyama/Gauss boundary, 1.88-2.47 Ma; and Gauss: Gauss normal interval, 2.47-3.40 Ma.

duce the age limit of the preserved magnetostratigraphy: (1) an increase in sedimentation rates to expand the record and (2) a decrease in the sub-bottom depth at which the primary magnetic remanence fades.

The deterioration of magnetic signals between 15 and $50 \mathrm{~m}$ downhole presumably results from the destruction of magnetic minerals by the reduction of iron (Karlin and Levi, 1985). This is indicated both because the sites with higher sedimentation rates ( $=$ higher productivity and higher organic carbon supply) show the greater effect and because sulfate reduction is highly correlated with magnetic signal deterioration.

Although magnetic intensities in Miocene sediments were generally at low levels, making interpretations difficult or impossible, Paleogene and Cretaceous sediments and basalt yielded interesting magnetic data. In places, intensities increased to interpretable values, and intervals of constant inclination were found that can be tentatively interpreted in terms of magnetostratigraphy.

In Site 803, mid-Oligocene sediments exhibit a mode of inclination distribution at $+9^{\circ}$. Assuming this represents primary magnetization, the paleolatitude is $4.5^{\circ}$, suggesting a total displacement of about $7^{\circ}$ since the last $30 \mathrm{Ma}$; that is, a rate of northward movement of $0.23 \% \mathrm{~m}$.y. This rate agrees roughly with earlier determinations for the Pacific Plate (Sager, 1987). In Site 807 , the attempt to determine Oligocene paleolatitudes did not yield unique results within the expected range. Presentfield overprinting may be responsible. Similar results were obtained for Eocene sediments, indicating the need for detailed shore-based demagnetization studies.

In the basalts of Site 807, natural remanent magnetizations are predominantly negative and steeper than $20^{\circ}$, as expected for normal polarity and a position south of $10^{\circ} \mathrm{S}$. Pass-through magnetic susceptibility measurements yielded high-resolution data for Pliocene-Pleistocene cores, which allowed us to correlate in detail. However, in Miocene sediments, susceptibility values became extremely low to negative and were clearly influenced by the diamagnetic calcite content.

For several sites $(805,806$, and 807$)$, high-resolution, wholecore, magnetic susceptibility data were obtained for APC cores and were recorded at $3-\mathrm{cm}$ intervals (Tarduno et al., this volume). These data allowed us to correlate in detail among the different holes at the same site and among sites (Fig. 31). The variations in susceptibility show Milankovitch spectral properties, indicating that abundances of magnetic minerals follow the fluctuations of climate (e.g., Bloemendal et al., 1988). Variations in source regions, wind regime, and diagenesis may be responsible.

\section{Diagenesis and Physical Properties}

Several diagenetic phenomena are of special interest when interpreting the sedimentary record: (1) the conversion of ooze to chalk, (2) the conversion of chalk to limestone, and (3) the mo- bility, precipitation, and aging of silica. These processes strongly influence the quality of the historic record and the echo properties of the sediment stack that result in the seismic profiles obtained. Diagenesis is a destructive process riding on the thermodynamic gradient toward equilibrium. However, timing and circumstances of lithification may retain clues to original conditions of deposition. The degree to which different sediments are predisposed to undergo diagenetic alteration is their "diagenetic potential" (Schlanger and Douglas, 1974). This should be a function of the amount of reactive materials preserved during the time of deposition and first burial.

The ooze-chalk transition is not represented by a sudden change in firmness (as might be implied from the specific depth assignment) but, rather, involves a substantial length of section, about $100-200 \mathrm{~m}$ (Fig. 32). Invariably, the transition is gradational and shows alternating layers of varying degrees of lithification. With this in mind, the patterns of the ooze-chalk transition and of silicification (as seen in the first appearance of chert nodules, looking downhole) are summarized in Table 5.

Notice that the range of depths for the ooze-chalk transition (182-339 m, a factor of 1.86) is greater than the range of ages (9.5-13.8 Ma, a factor of 1.45) and that the two run in opposite directions (the deepest transition also being the youngest). It may be that the transition from ooze to chalk was favored by aging as well as by depth of burial, with the product between these two factors tending to be roughly constant in this data set. The greater range in the depth factor might be interpreted as indicating that depth of burial was less important than age in causing lithification in these sediments. Alternatively, noting that the ages of the chalk transition are in the same rank order as the depths of deposition, one might argue that the sites least affected by carbonate dissolution were the most active diagenetically, as postulated by Schlanger and Douglas (1974).

Finding the rare chert nodules that occurred in the Neogene portion of the record is a matter of luck. Still, the shallowest occurrence of such nodules is indeed in the site having the most preserved silica and the highest sedimentation rates (Site 806). The inference that silica abundance was crucial to chert formation is strengthened by the observation that chert beds invariably appear in the Eocene record, when silica was abundant (ODP Sites 803 and 807 and DSDP 289). In addition, the "radiolarite" noted in Site 804 at 200 mbsf occurs in connection with a hiatus, where carbonate was removed and silica was concentrated.

Limestones first appear just below $1000 \mathrm{~m}$ in Site 807 and dominate below $1100 \mathrm{~m}$. Site 803 has no limestone sequence, either because it was below the CCD for much of pre-Oligocene time or because carbonate was removed during periods of erosion within that interval.

The significance of diagenesis to distribution of physical properties was mentioned above in the context of seismic stratigraphy. Lithification affects both rigidity and density, which govern the $P$-wave velocity. In Site 807 , for example, a distinct increase occurs in the trend of increasing velocity below $300 \mathrm{mbsf}$ (marked " $R$ " in Fig. 33), whereas density jumps to higher values at 380 mbsf (marked "B" in Fig. 33). Rigidity increased rapidly and pore space was eliminated in this interval. The "official" transition at 293 mbsf (as determined visually) most closely corresponds to a sudden increase in velocity, as measured on board the ship, suggesting that interparticle binding at this point was strong enough to withstand the stress of recovery and pressure release.

In Site 806, a marked change in the velocity-depth gradient also occurs near the level where lithification first became important, as seen by the occurrence of porcellanite nodules ( 240 mbsf, 6-7 Ma; Fig. 23). At the ooze-chalk transition (339 mbsf), the character of the velocity profile changes: above this level, 


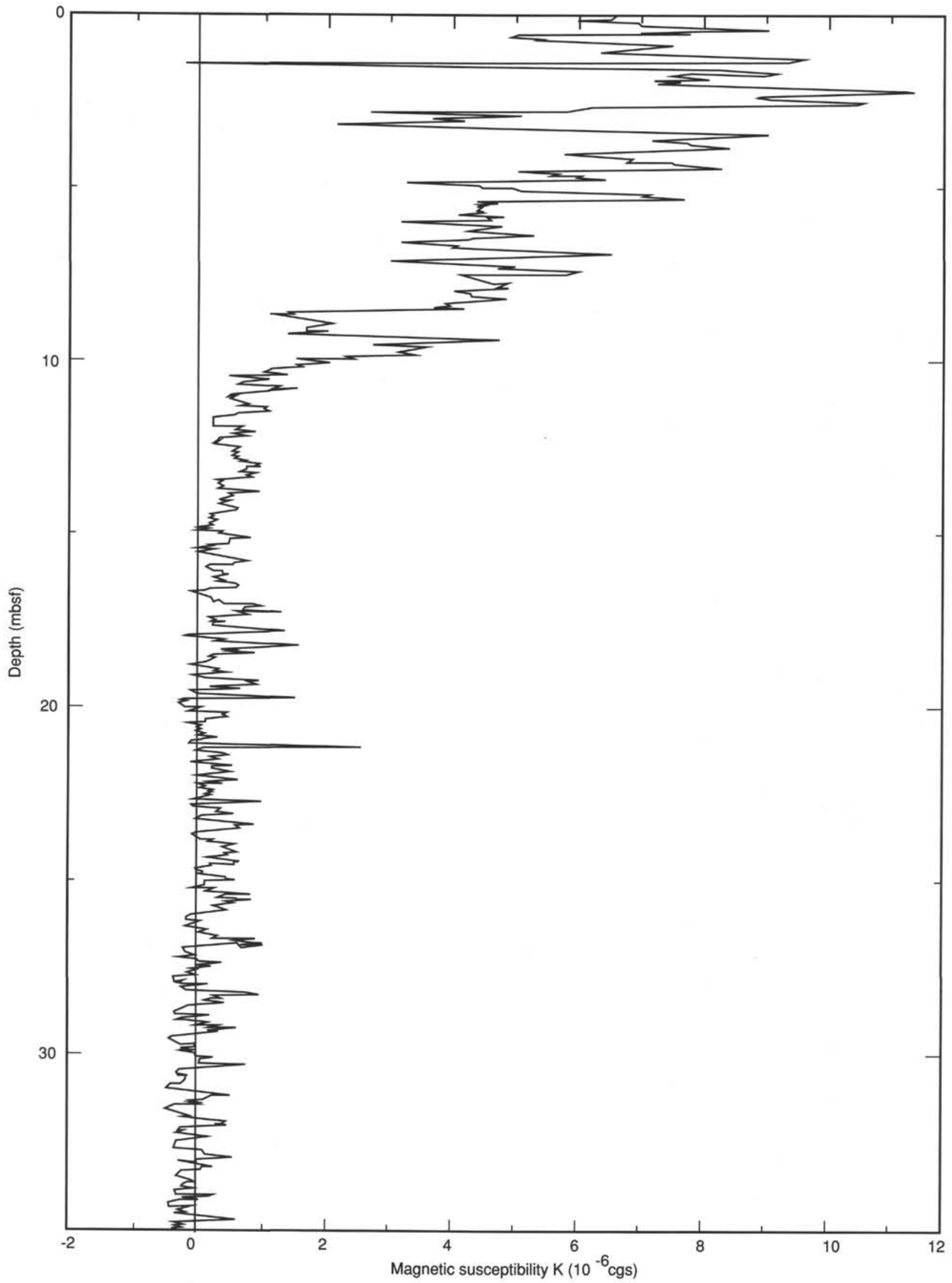

Figure 31. Whole-core magnetic susceptibility for Hole 806A using an 80-mm MS2C Bartington sensor. Note the rapid reduction below $10 \mathrm{mbsf}$ and indications of cyclicity at low levels of susceptibility. From Tarduno et al. (this volume). 


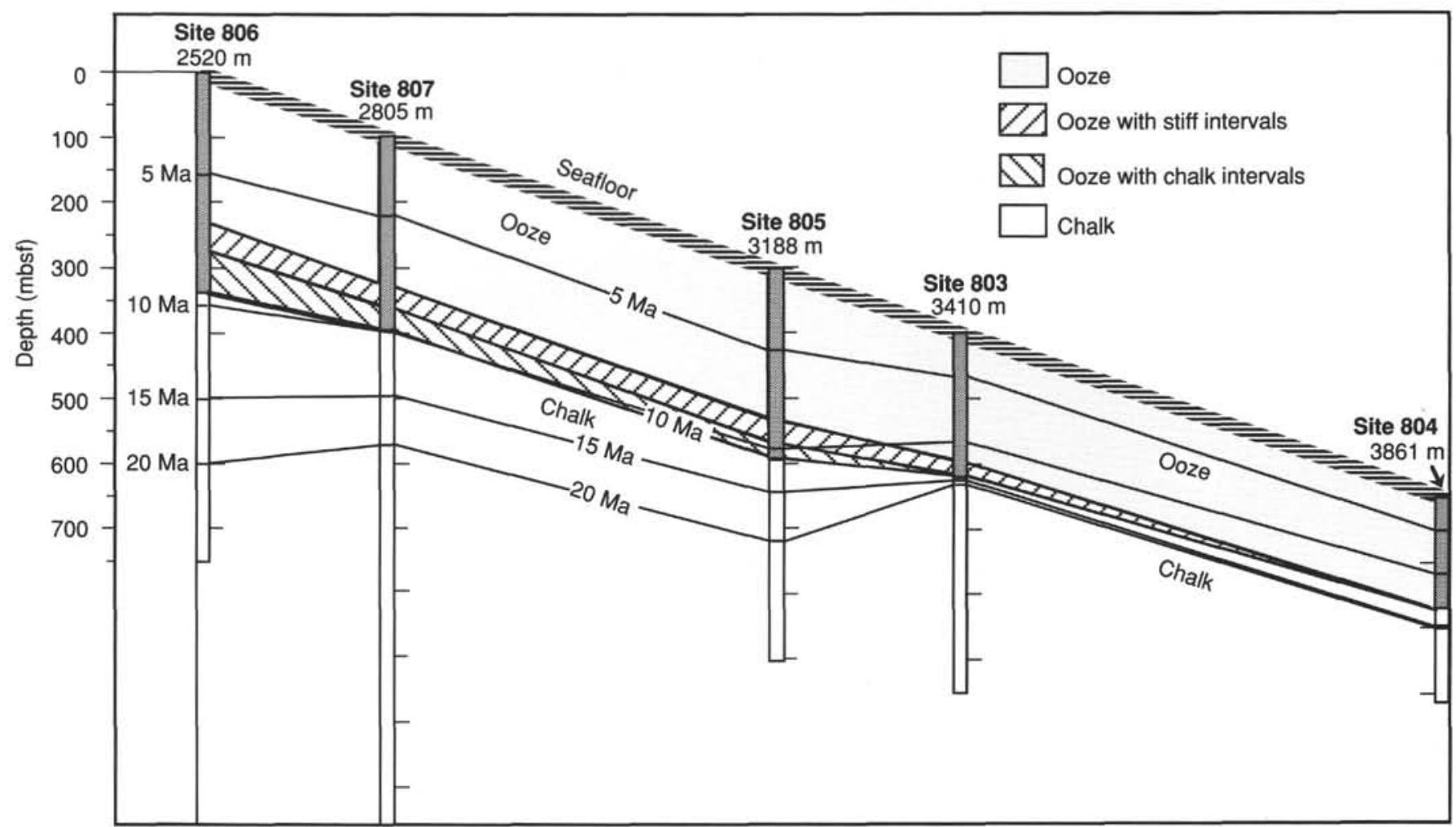

Figure 32. Location of ooze-chalk transition at each Leg 130 site. Drawn by D. Masher.

Table 5. Depth of ooze-chalk transition and occurrences of chert at each Leg 130 site.

\begin{tabular}{|c|c|c|c|c|c|}
\hline \multirow[b]{2}{*}{ Site } & \multirow{2}{*}{$\begin{array}{c}\text { Ooze-chalk } \\
\text { level } \\
\text { (m) }\end{array}$} & \multirow[b]{2}{*}{$\begin{array}{l}\text { Age } \\
\text { (Ma) }\end{array}$} & \multicolumn{2}{|c|}{ Chert nodules } & \multirow[b]{2}{*}{ Other shallow occurrences } \\
\hline & & & $\begin{array}{l}\text { Level } \\
\text { (m) }\end{array}$ & $\begin{array}{c}\text { Age } \\
\text { (Ma) }\end{array}$ & \\
\hline 803 & 217 & 13 & 540 & 37 & Chert beds, mid-Eocene \\
\hline 804 & 182 & $13.5-14$ & & & "Radiolarite," 200 m \\
\hline 805 & 288 & $10.5-11.5$ & 344 & 14 & "Chert?", late Oligocene \\
\hline 806 & 339 & $9-10$ & 240 & $6-7$ & Also 310,509 , and $514 \mathrm{~m}$ \\
\hline 807 & 293 & $10-10.5$ & 252 & 8 & Chert bed, $960 \mathrm{~m}, 39 \mathrm{Ma}$ \\
\hline
\end{tabular}

high-frequency variations are pronounced; below it, they are indistinct. Similar phenomena were observed at the other sites.

\section{Diagenesis and Interstitial Water Chemistry}

Diagenetic processes involve mobilization and precipitation of carbonate and silica and thus should be observable in the composition of interstitial waters; that is, in the concentrations of calcium, strontium, and silica. Much of the reactivity of sediments owes to the presence of organic matter, which is reflected in profiles of oxygen and sulfate (Fig. 34). Reduction of sulfate is evident down into uppermost Miocene sediments. Reduction increases alkalinity, whereas carbonate precipitation decreases it. Of special interest is the dissolved strontium, which increases in response to the recrystallization of biogenic carbonate (Gieskes, 1981; Fig. 35).

The chemical species analyzed show one of three patterns, mostly as follows:

1. "Hingepoint" patterns, with a rapid change in concentration from a value set by bottom-water composition to some typical value inside the sediment, commonly in an interval between 6 and $8 \mathrm{Ma}$ old. Below, the hingepoint concentrations stay more or less constant or have a low gradient. Sulfate, ammonia, silica, and strontium profiles exhibit this pattern (Figs. 34 and 35 ).

2. Patterns similar to the those of the hingepoint, but which display a marked decrease below the hingepoint; that is, a maximum occurs. Alkalinity shows this type of distribution, with the maximum appearing in sediments between 4 and 14 Ma (Fig. 34).

3. Patterns that can be represented approximately by stating the surface concentration and another concentration near the bottom of the section; that is, a general trend with depth. Both potassium and rubidium profiles exhibit this type of distribution (Fig. 36).

The first two patterns (hingepoint and maximum) are related to diagenesis, and the third (general trend), for the most part, presumably reflects an exchange between ocean and basement. Calcium and alkalinity exhibit a mixed pattern, somewhere between the hingepoint and general trend, indicating a complex origin. In these cases, the effects of sulfate reduction, carbonate precipitation, and basement influence must be considered. Sites 806 and 807 show the greatest initial increases in alkalinity within the section younger than $10 \mathrm{Ma}$, as expected from sulfate reduction values (Fig. 34). In contrast, Sites 803 and 804 show little increase in alkalinity. All values decrease deeper in the section below the mid-Neogene maximum, suggesting precipitation of carbonate or exchange with basement or both.

The hingepoint may be interpreted as the bottom part of a reaction zone that moved upward as sedimentation proceeded. The reactive sediments are younger than $8 \mathrm{Ma}$ on the whole. Along the gradient above the hingepoint, there is diffusional exchange with bottom water. Below it, a tendency exists for reprecipitation, as interstitial water concentrations slowly increase toward equilibrium values. There may be a decrease in permeability below the hingepoint, allowing for concentrations below to build up to higher levels, despite a decrease in reaction rates. 

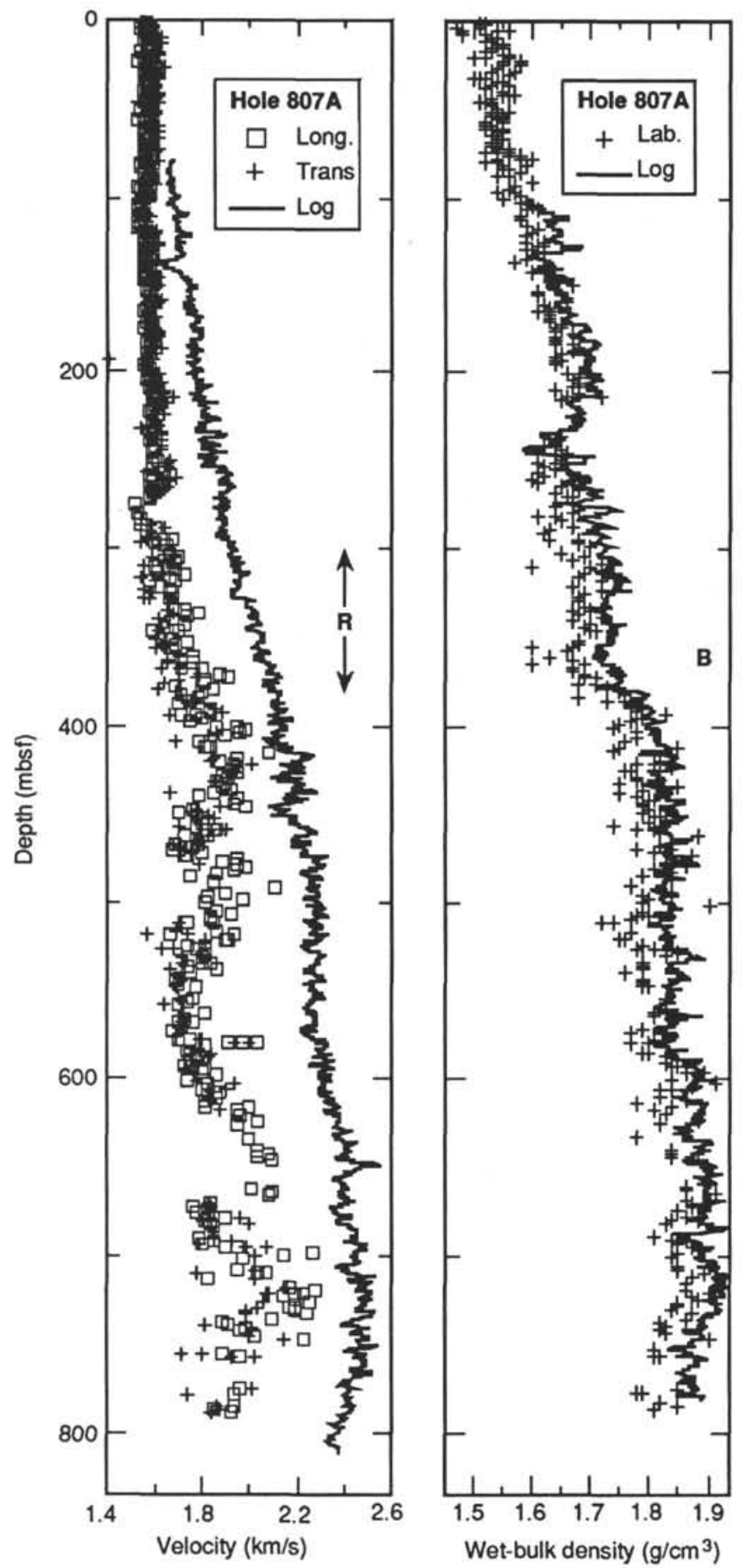

Figure 33 . Velocity and bulk density profiles, Site 807 , as measured by logging and on deck. The breaks in trends $(R=$ ramp and $B=$ break $)$ appear between 300 and $380 \mathrm{mbsf}$, suggesting a change in the nature of lithification at that depth.

Major trends in the composition of interstitial water bearing on diagenesis are summarized below (Table 6). Note that, in essence, the patterns are identical for all rows shown, except for calcium. The last two rows refer to sedimentation rate and water depth of the sites, respectively. Thus, sedimentation rates for the last $5 \mathrm{Ma}$, as well as depth of deposition, are correlated with the factors controlling sulfate reduction and with silica and stron- tium content in the late Neogene portion of the section, but less so for calcium content. The equatorial position of Site 805 makes up for its greater depth, in comparison with Site 807 , so that sedimentation rates are identical over the last $5 \mathrm{Ma}$, and reactivity tends to be slightly greater in Site 805 .

In Site 806 , the high values of missing sulfate, of silica concentration, and of strontium indicate that (at the 5-Ma age level) the sediments were bathed in interstitial waters that differed more from the composition of seawater than those in the other sites. Thus, at the same age level within this interval, (1) the reduction of iron mineral should be more advanced, (2) the likelihood of silica precipitation should increase, and (3) the recrystallization of carbonate should be faster at Site 806 than at the other sites. The problem with postulating statements about the relative speed of reaction rates is that at some age level, concentrations alone cannot give this information.

If we assume that the coefficients of diffusion are roughly the same in the various sites in sediments less than $5 \mathrm{Ma}$ old, we can make some observations about the relative rates of diffusion of dissolved substances out of the sediment. One can see from the normalized values in parentheses in Table 6 that the gradients of missing sulfate are about the same for the different sites, except for Site 807 , which has a distinctly weaker gradient. Presumably, this relates to its position well off the equator $\left(3.5^{\circ}\right)$. This would seem to indicate that oxidation of organic matter proceeds at about the same pace in the different sites, because the same amount of sulfate deficit was generated. This implies that Site 806 , with considerably more organic matter delivered (because of its shallow depth), should retain more of this matter than the other sites, so that in principle sulfate reduction continued much longer here.

For silica, the gradients are similar for Sites 805,806 , and 807 , but they are considerably greater for deeper Sites 803 and 804. Perhaps the greater abundance of opal in these sites (from dissolution of carbonate) is the reason. If the coating of opal surfaces or the alteration by surface reactions is important for determining dissolution rates, then a sediment having a higher opal content (and lower contaminant content) should provide silica at a higher rate and, hence, show the greater depth gradient. In any case, the sites having the higher sedimentation rates appear to release silica at a lesser rate. This suggests that rapid burial is an advantage for retaining siliceous fossils in sediment.

Strontium gradients are similar for the different sites (except for being somewhat high in Site 803). Thus, recrystallization of carbonate should proceed at about the same pace in the various sites. However, this does involve the younger sediments in the sites having the higher sedimentation rates, so that one might contend that recrystallization was favored by the initial preservation of reactive carbonate in those sites. Presumably, calcium content was affected by this process. However, calcium values tend to be erratic, indicating that a number of different processes were involved when determining the patterns.

The pattern for ammonia mirrors that of sulfate, except with the opposite sign. Thus, the same factor may be responsible; that is, the availability of organic matter. The stoichiometry suggests that ammonia was being lost, presumably to uptake by clay minerals.

Magnesium gradients were influenced by basalt alteration reactions at depth and exhibit the usual negative correlation $(R=$ 0.97 ) with calcium (Fig. 36). Thus, calcium concentrations likewise reflect reactions with basalt.

\section{GRAPE Density Variations}

The gamma-ray attenuation porosity evaluator (GRAPE) portion of the multisensor track (MST) unit measures the saturated bulk density of sediments in unopened cores by tracking the amount of attenuation of gamma rays aimed at the core, with a 

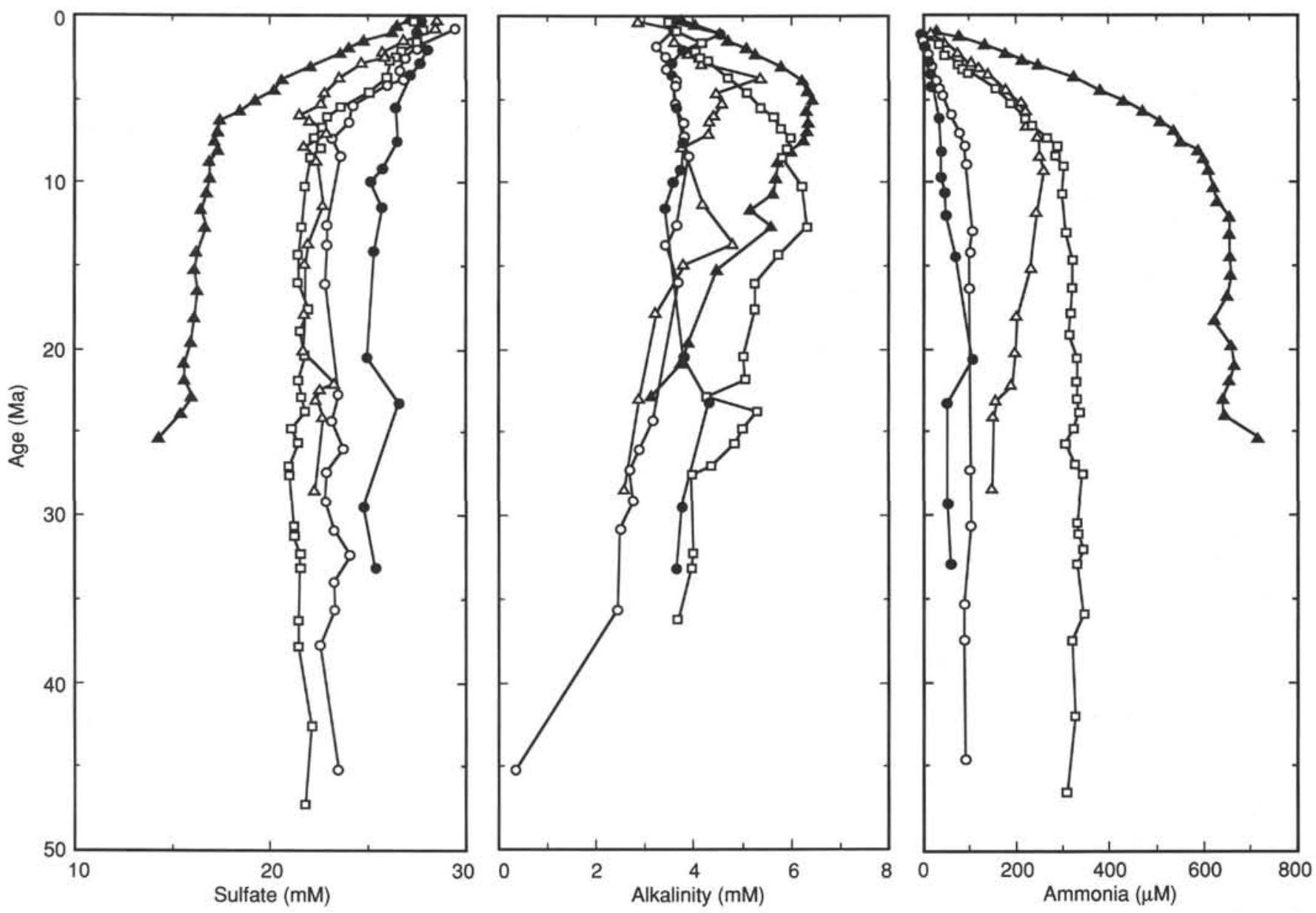

Figure 34. Dissolved sulfate, alkalinity, and ammonia in the Leg 130 sites, plotted vs. age of sediment. Data and figures from Delaney et al., this volume. Open circles $=$ Site 803 , closed circles $=$ Site 804 , open triangles $=$ Site 805 , closed triangles $=$ Site 806 , and open squares $=$ Site 807 .

sampling interval from 2 to $3 \mathrm{~cm}$. Although the exact relationship of attenuation to true density is a matter of calibration, results yield a reliable index of density variations that can be used for hole-to-hole and site-to-site correlations within the APC range (Fig. 37). In addition, these data provide information about the nature of Milankovitch cycles as a function of age within the Neogene record (Jansen et al., this volume).

The extraction of Milankovitch frequencies from these records allows one to check on the time scale adopted. If the tiepoints for the time scale are correct, the fluctuations should show peak power at the standard periods (eccentricity, obliquity, precession); if not, the peaks should be shifted in a systematic manner. Such a test was performed for the data from the upper 25 mbsf in Hole 806B; it gave excellent results (Fig. 38). The Pleistocene record shows the expected peaks, although the power distributions exhibit some idiosyncracies that warrant study.

\section{SUMMARY AND OUTLOOK}

\section{Highlights}

Important first results of Leg 130 include the following:

1. Recovery of complete Neogene sections at several depths that provided materials for detailed biostratigraphic and paleoceanographic studies and already has yielded new insights about the global ocean carbon cycle.
2. Acquisition of extensive logging records and high-resolution, physical properties data (including magnetic susceptibility) that permitted detailed correlation from hole to hole and from site to site and that provided the basis for interpreting acoustic reflectors, which now appear significant in a new light.

3. Recovery of two complete $\mathrm{K} / \mathrm{T}$ boundary transitions, one above and one below the CCD, which raises questions about the unusual preservation of the $\mathrm{K} / \mathrm{T}$ transition in this setting, especially below the CCD.

4. Deep penetration into basement and unprecedented recovery of basalt on an oceanic plateau, which opens the way for thorough investigations of the origin and early history of Ontong Java Plateau (and by analogy other oceanic plateaus).

Drilling results suggest that changes in the global ocean climate and in the carbon cycle govern productivity and preservation patterns and that these changes exceed in amplitude the effects of equatorial position and depth of deposition. In the Neogene deposits, what is reflected in the sedimentation rate patterns are changes in the entire ocean-climate system rather than regional changes. We infer this from the pronounced coherency among patterns, independent of depth or position relative to the equator. Although an erroneous age scale can produce coherency in rates artificially, we think that the errors inherent in the scale used are not large enough to create all or most of this effect. In any case, carbonate stratigraphy, which 

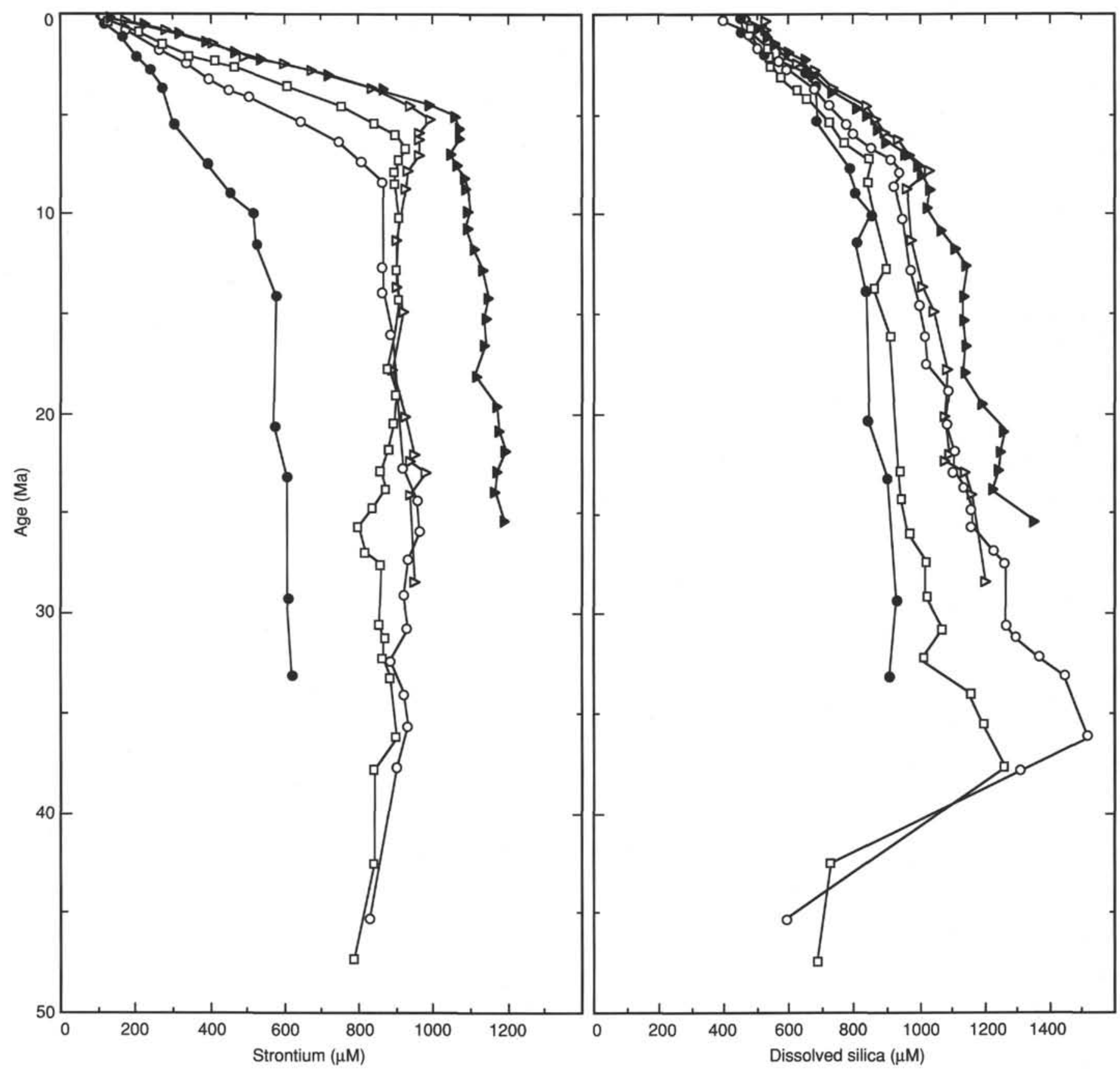

Figure 35. Concentrations of dissolved strontium and silica in the Leg 130 sites, plotted vs. age of sediment. Data and figures from Delaney et al. (this volume). See Figure 34 for an explanation of symbols used.

depends much less on the age scale, exhibits the same sort of across-depth and across-latitude coherency in greater detail.

Sedimentation rates in the Neogene were found to vary by more than a factor of 2 , with a striking maximum $(50-60 \mathrm{~m}$ / m.y.) in the latest Miocene to early Pliocene sections throughout the depth transect sampled. Fluctuations in carbonate on the million-year scale are highly coherent among depths over the last $12 \mathrm{Ma}$, but they are less so before that. A striking decline in sedimentation rate occurred at the end of the Pliocene. This decline (previously noted in Site 586 sediments higher up on the plateau by Shipboard Scientific Party, 1986) is surprising for two reasons: (1) the great increase in planetary temperature gradient in the Northern Hemisphere, which set in with the closure of the Panama Straits and the buildup of northern ice after 3.5
Ma, should have increased the trade winds and the strength of equatorial upwelling, and (2) the increased erosion of northern continents, resulting from the onset of the northern ice ages, should have delivered an increased amount of material, including calcium carbonate, thus predisposing the entire ocean system for increased sedimentation rates.

We propose that both these factors were active, but that they led (1) to a pile-up of warm water in the western equatorial $\mathrm{Pa}$ cific, making upwelling less effective; (2) to an increase in the deposition of continental slope sediments, where increased coastal productivity and increased terrigenous influx conspired to sequester organic matter and the nutrients contained within it; and (3) to a shifting of remaining nutrients from upper waters to deep waters by increased coupling between intermediate and 

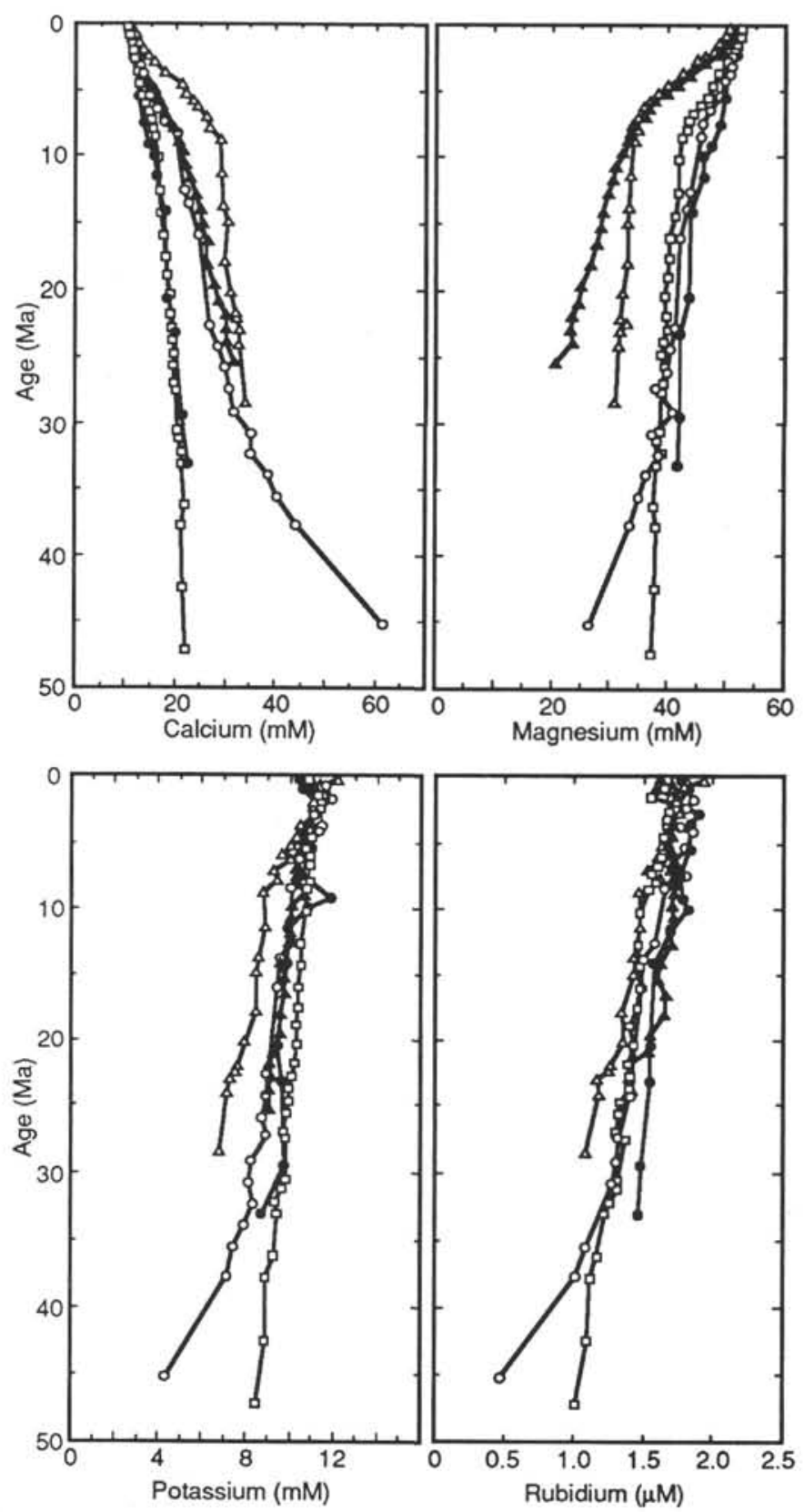

Figure 36. Concentrations of dissolved calcium, magnesium, potassium, and rubidium. Data and figures from Delaney et al. (this volume). See Figure 34 for an explanation of symbols used.

surface waters (in analogy to glacial-interglacial shifts in vertical fractionation; Boyle, 1988; Duplessy, 1988). Thus, the nutrient content of the ocean declined to its present-day low levels.

Another factor tied to trade winds also may be important for producing the striking decrease in sedimentation rates since the late Pliocene: the effect of dust on the productivity of the ocean. If iron is limiting to productivity (as urged by Martin et al., 1990), the availability of iron in high latitudes should strongly modify the amount of preformed nutrients in intermediate waters, which would bear on tropical productivity. As the planet entered the modern ice age, some $3 \mathrm{~m} . \mathrm{y}$. ago, iron-containing dust should have become more abundant in the atmosphere, in analogy to what happens during glacial conditions (Janecek, 1985; Petit et al., 1990). Surface waters in high latitudes then might have been stripped of nutrients more efficiently, leaving
Table 6. Summary of interstitial water composition.

\begin{tabular}{|c|c|c|}
\hline Type & Rank & $\begin{array}{l}\text { Values in } \mathrm{mM} \text { at } 5 \mathrm{Ma} \\
\text { (normalized gradient) }\end{array}$ \\
\hline $\mathrm{SO}_{4}$ & $806,805,807,803,804$ & $\begin{array}{l}11.0,7.5,6,5.7,3.3 \\
(1.0,0.88,0.71,1.2,1.1)\end{array}$ \\
\hline $\mathrm{SiO}_{2}$ & $806,805,807,803,804$ & $\begin{array}{l}0.85,0.85,0.76,0.70,0.70 \\
(1.0,1.3,1.2,1.9,3.0)\end{array}$ \\
\hline $\mathrm{Sr}$ & $806,805,807,803,804$ & $\begin{array}{l}1.06,0.99,0.82,0.62,0.3 \\
(1.0,1.2,1.0,1.4,1.0)\end{array}$ \\
\hline $\mathrm{Ca}$ & $805,806,803,807,804$ & $\begin{array}{l}22.5,15.4,15.0,13.0,13.0 \\
(1.0,0.5,1.2,0.6,1.7)\end{array}$ \\
\hline SR & $806,805,807,803,804$ & $32.6,25.2,25.2,14.0,8.8 \mathrm{~m} / \mathrm{m} . \mathrm{y}$ \\
\hline WD & $806,807,805,803,804$ & $2.5,2.8,3.2,3.4,3.9 \mathrm{~km}$ \\
\hline
\end{tabular}

Notes: Shown are species measured, the rank order of sites with respect to concentrations, and the values at the 5-Ma level for each site in that same order. In parentheses are normalized concentration values, that is, indexes of the actual downhole gradients, in the late Neogene sediments. Normalization was done by dividing the concentrations at $5 \mathrm{Ma}$ by the sedimentation rate, then setting the value of the first site equal to unity. If all sites have the same gradient, all values are unity. Sulfate is shown as the difference of the measured amount to $30 \mathrm{mM}$; this difference is assumed to be the sulfate consumed. The data are from the summary of inorganic chemistry (Delaney et al., this volume). Sedimentation rates (SR) and water depth (WD) are also shown.

intermediate waters barren and reducing the efficiency of tropical upwelling.

A large number of acoustic reflectors are synchronous and are associated in time with important paleoceanographic events. These can be traced among sites at different depths, despite being produced by different mechanisms in some cases. Extensive downhole logging provides the control for calculating the exact depth of reflectors; thus, they can be tied to biostratigraphic and lithostratigraphic datum points. Some reflectors are strongly related to diagenesis or are enhanced by diagenesis, others mark the position of hiatuses, which in turn line up with condensed sections, emphasizing the importance of carbonate dissolution pulses. Such pulses tend to occur in groups, suggesting transitional hypersensitivity of the system.

The hypothesis that paleoceanographic events ultimately dominated seismic stratigraphy on Ontong Java Plateau (Schlanger and Douglas, 1974; Berger and Mayer, 1978; Mayer et al., 1985, 1986) has been amply confirmed. The uppermost reflectors of a group of reflectors (second only to basement in strength, the Ontong Java Series) mark the time of a major reorganization of the silica budget of the ocean within the upper Eocene. As for the record of Ontong Java Plateau, this was when the world began to look "modern." Since that time, sedimentation has been uniform with regard to rates and types of material delivered: it consists of pure calcareous ooze that was delivered at a rate of almost $30 \mathrm{~m} / \mathrm{m}$.y.. Thus, some time during the late Eocene, the great geochemical fractionation machine was turned on, silica was sequestered into the margins and high latitudes, and little else except carbonate was left for the tropical pelagic ocean. From that time on, changes were mainly recorded as changes in carbonate supply, dissolution, and winnowing, and these effects (by default) became the basis for making reflectors.

The ooze-chalk transformation occurs earlier in the thicker sediment stacks at shallower water depths. Overburden, the initial condition of sediments at burial, and age are all important for controlling the rates of diagenesis. This transformation is invariably transitional and is marked by the alternation of chalk and ooze. In this zone, contrasts of density and sound velocity are enhanced and thus are favorable for the development of seemingly diachronous reflectors.

Recovery of the K/T boundary, apparently in complete sections, at Sites 803 and 807 , demonstrates the presence of a deep 
A

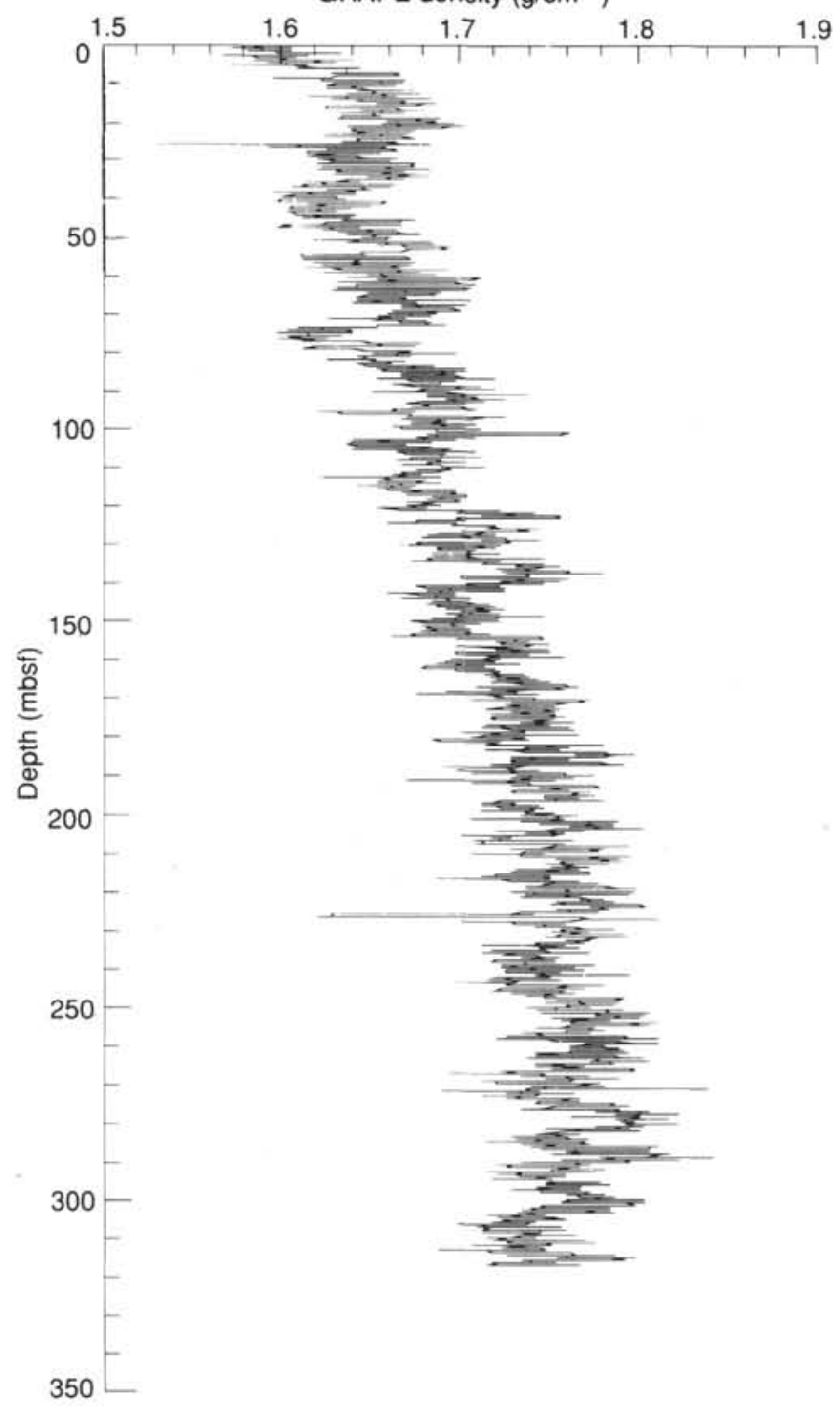

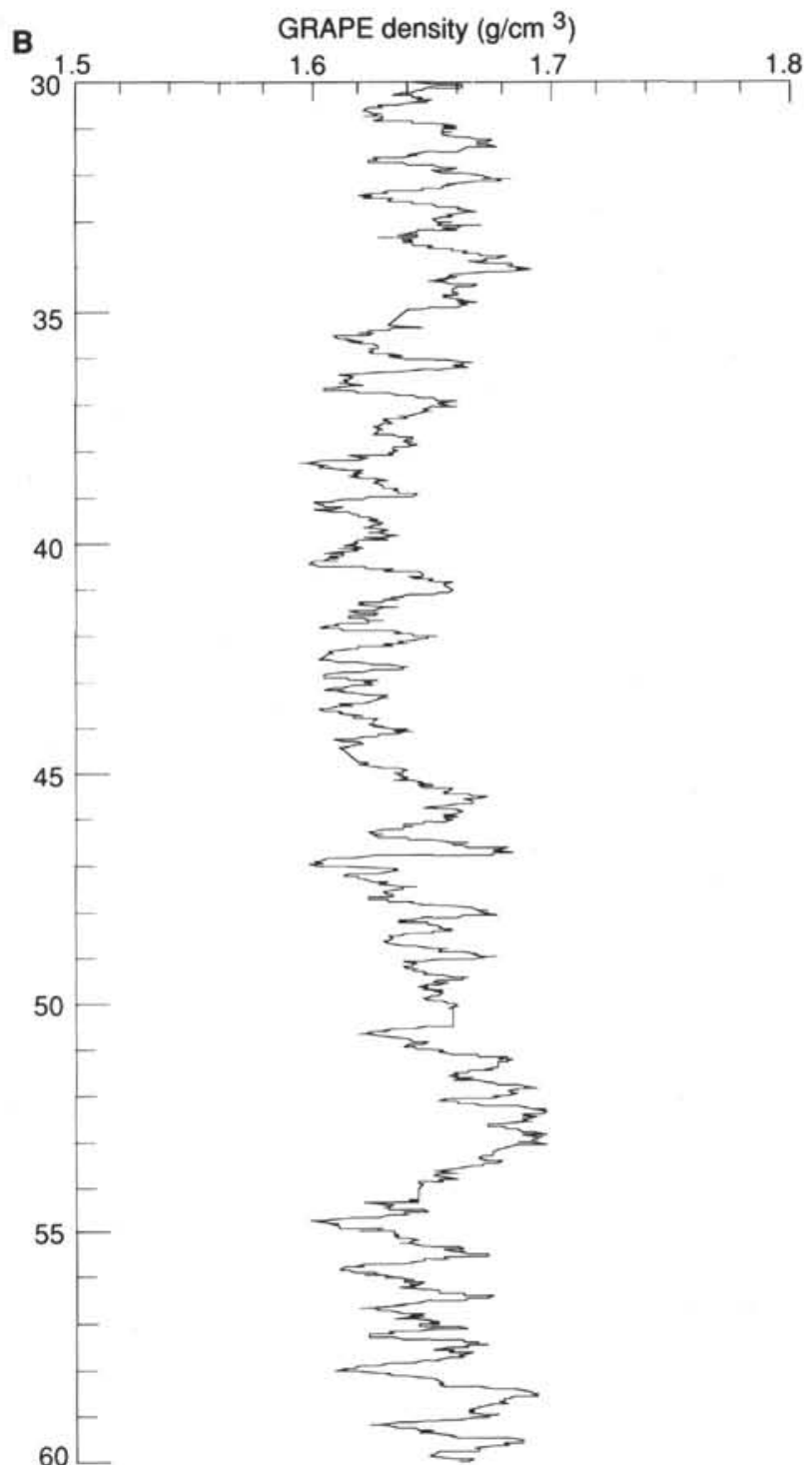

Figure 37. GRAPE density data from Hole 806B. Data are smoothed by a 10-pt Gaussian filter. Figure by Jansen et al. (this volume).

CCD across the transition: one sequence is calcareous, the other is noncalcareous. Estimating the depth of deposition at the shallower site as nearly $3 \mathrm{~km}$ and that of the deeper site as approximately $3.5 \mathrm{~km}$ brackets the position of the CCD at that time. The shallower site shows a volcanic ash layer immediately preceding the $\mathrm{K} / \mathrm{T}$ boundary (as placed by microfossil content and verified by stable isotopes; R. Corfield, pers. comm., 1990). The deeper site shows evidence of volcanic activity throughout the $\mathrm{K} / \mathrm{T}$ transition. This volcanism may be partly responsible for the striking fact that the $\mathrm{K} / \mathrm{T}$ boundary was preserved as the only short sequence within an extensive hiatus. Alternatively or in addition, excess silica built up in deep waters because of the demise of diatoms and thus facilitated early cementation.

The basalts cored at Sites 803 and 807 (26 and 149 m penetration, respectively) are predominantly fine grained, aphyric, and olivine bearing. They represent flows that may have been erupted from submarine vents in rapid succession during the mid-Cretaceous. Late stages of eruption also are indicated as occurring after a lapse of considerable time. At Site 807, pillowed lava flows buried sediments at least twice. One thick flow
$(28 \mathrm{~m})$ was penetrated at Site 807 , indicating that flood basalts were an important element in the construction of the plateau. In fact, these flows may have been dominant in the makeup of the plateau. However, our sampling mainly recovered the products of late-stage volcanism (with numerous pillow lavas) and evidence for hydrothermal activity. The latest flows show signs of having been derived from more evolved magma. Paleolatitudes from magnetic inclinations in the basalt suggest that the Ontong Java Plateau moved coherently with the Pacific Plate since the Early Cretaceous.

\section{Outlook}

A vast array of measurements were performed on board the JOIDES Resolution, including extensive logging. The analysis of these data has just begun, and much additional information is expected from sedimentological, petrological, geophysical, chemical, paleontological, and isotopic studies of the material collected. The major results presented here help to define the questions that need answers and indicate the directions in which future studies might follow. 


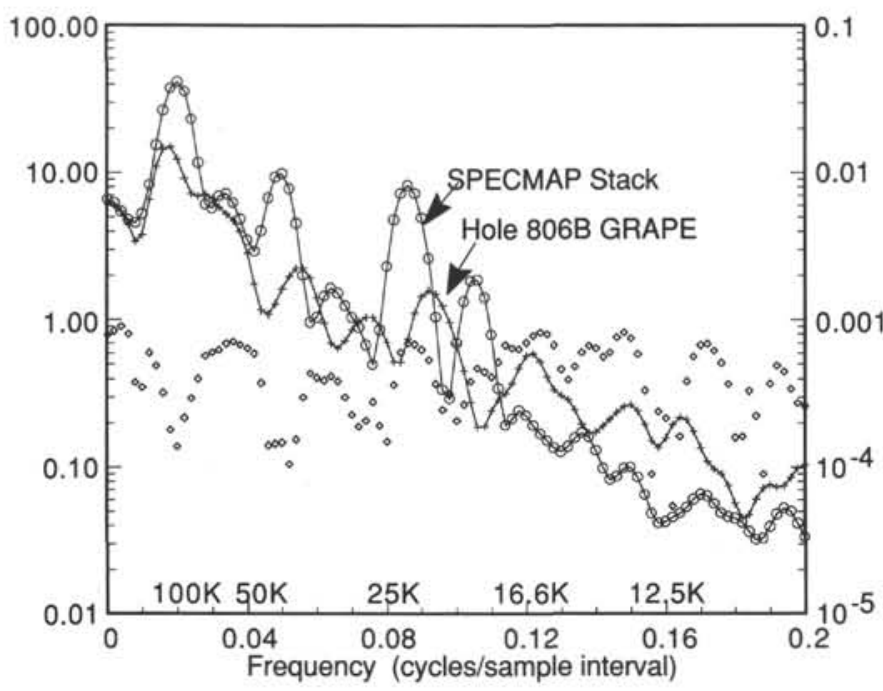

Figure 38. Spectral analysis of the smoothed GRAPE record from the upper $25 \mathrm{~m}$ in Hole 806B (Pleistocene), compared with the SPECMAP record of Imbrie et al. (1984). Time scale based on shipboard age model. Figure by Jansen et al. (this volume). Unconnected open diamonds = coherency.

\section{ACKNOWLEDGMENTS}

The success of Leg 130 was a result of the efforts of a great number of people, beginning with planning and preparation and culminating in drilling, recovery, sampling, and analysis. This summary of shipboard results represents one tangible product of these efforts. We thank those who worked in committee and those who surveyed the sites and helped to plan them. We thank Captain Edwin Oonk and his officers, engineers, and crew for getting us safely there and back. We are grateful to the Operations Manager, Gene Pollard, and his engineers, and to Ken Horne and his drilling crew. The alertness of the drillers during repetitive and routine operations saved the day more than once. We appreciate the alacrity and good spirit of the rigfloor crew, who saved us the time that made record recovery possible for both pelagic ooze and plateau basalt. Our special thanks go to the ODP technical and logistics personnel, whose skills and devotion were of crucial importance and who had more on their hands than what might be reasonably expected. We thank ODP staff for special efforts in onshore support. Last but not least, we are grateful to the stewards and the baker for making things comfortable on board SEDCO/BP 471, the JOIDES Resolution.

\section{REFERENCES}

Alvarez, L. W., Alvarez, W., Asaro, F., and Michel, H. V., 1980. Extraterrestrial cause for the Cretaceous-Tertiary extinction. Science, 208: $1095-1108$.

Arrhenius, G., 1952. Sediment cores from the east Pacific. Rep. Swed. Deep-Sea Exped. 1947-1948, 5:1-227.

Arthur, M. A., Dean, W. E., and Schlanger, S. O., 1985. Variations in the global carbon cycle during the Cretaceous related to climate, volcanism, and changes in atmospheric $\mathrm{CO}_{2}$. In Sundquist, E. T., and Broecker, W. S. (Eds.), The Carbon Cycle and Atmospheric $\mathrm{CO}_{2}$ : Natural Variations Archean to Present. Am. Geophys. Union Monogr., 32:504-529.

Backman, J., 1979. Pliocene biostratigraphy of DSDP Sites 111 and 116 from the North Atlantic Ocean and the age of the Northern Hemisphere Glaciation. Stockholm Contrib. Geol., 32:115-137.

Barron, J. A., and Baldauf, J. G., 1989. Tertiary cooling steps and paleoproductivity as reflected by diatoms and biosiliceous sediments.
In Berger, W. H., Smetacek, V. S., and Werfer, G. (Eds.), Productivity of the Oceans: Present and Past: New York (Wiley-Interscience), 341-354.

Barron, J. A., Keller, G., and Dunn, D. A., 1985. A multiple microfossil biochronology for the Miocene. In Kennett, J. P. (Ed.), The Miocene Ocean: Paleoceanography and Biogeography. Mem. Geol. Soc. Am., 163:21-36.

Berger, W. H., 1970. Biogenous deep-sea sediments: fractionation by deep-sea circulation. Geol. Soc. Am. Bull., 81:1385-1401.

Berger, W. H., and Johnson, T. C., 1976. Deep-sea carbonates: dissolution and mass wasting on Ontong Java Plateau. Science, 192:785787.

Berger, W. H., and Mayer, L. A., 1978. Deep-sea carbonates: acoustic reflectors and lysocline fluctuations. Geology, 6:11-15.

Berger, W. H., and Roth, P. H., 1975. Oceanic micropaleontology: progress and prospects. Rev. Geophys. Space Phys., 13:561-635.

Berger, W. H., Vincent, E., and Thierstein, H. R., 1981. The deep-sea record: major steps in Cenozoic ocean evolution. Spec. Publ., Soc. Econ. Paleontol. Mineral., 32:489-504.

Berger, W. H., and Winterer, E. L., 1974. Plate stratigraphy and the fluctuating carbonate line. In Hsü, K. J., and Jenkyns, H. C. (Eds.), Pelagic Sediments on Land and Under the Sea. Spec. Publ., Int. Assoc. Sedimentol., 1:11-48.

Berggren, W. A., and Hollister, C. D., 1977. Plate tectonics and paleocirculation-commotion in the ocean. Tectonophysics, 38:11-48.

Berggren, W. A., Kent, D. V., and Van Couvering, J. A., 1985. The Neogene: Part 2, Neogene geochronology and chronostratigraphy. In Snelling, N. J. (Ed.), The Chronology of the Geological Record. Mem. Geol. Soc. (London), 10:211-260.

Bloemendal, J., Lamb, B., and King, J., 1988. Paleoenvironmental implications of rock-magnetic properties of late Quaternary sediment cores from the eastern equatorial Atlantic. Paleoceanography, 3:6187.

Boyle, E. A., 1988. Vertical oceanic nutrient fractionation and glacial/ interglacial $\mathrm{CO}_{2}$ cycles. Nature, 331:55-56.

Bralower, T. J., and Thierstein, H. R., 1984. Low productivity and slow deep-water circulation in mid-Cretaceous oceans. Geology, 12:614618.

Bramlette, M. N., 1965. Massive extinctions in biota at the end of Mesozoic time. Science, 148:1696-1699.

Duplessy, J. C., Shackleton, N. J., Fairbanks, R. G., Labeyrie, L., Oppo, D., and Kallel, N., 1988. Deep-water source variations during the last climatic cycle and their impact on global deep-water circulation. Paleoceanography, 3:343-360.

Flohn, H., 1985. Das Problem der Klimaänderungen in Vergangenheit und Zukunft: Wissenschaftliche Buchgesellschaft Darmstadt, BRD Germany.

Gieskes, J. M., 1981. Deep-sea drilling interstitial water studies: implications for chemical alteration of the oceanic crust, Layers I and II. In Warme, J. E., Douglas, R. G., and Winterer, E. L. (Eds.), The Deep Sea Drilling Project: A Decade of Progress. Spec. Publ., Soc. Econ. Paleontol. Mineral., 32:149-167.

Haq, B. U., Hardenbol, J., and Vail, P. R., 1987. Chronology of fluctuating sea levels since the Triassic. Science, 235:1156-1167.

Hussong, D. M., Wipperman, L. K., and Kroenke, L. W., 1979. The crustal structure of the Ontong Java and Manihiki oceanic plateaus. J. Geophys. Res., 84:6003-6010.

Imbrie, J., Hays, J. D., Martinson, D. G., McIntyre, A., Mix, A. C., Morley, J. J., Pisias, N. G., Prell, W. L., and Shackleton, N. J., 1984. The orbital theory of Pleistocene climate: support from a revised chronology of the marine delta $\delta^{18} \mathrm{O}$ record. In Berger, A., Imbrie, J., Hays, J., Kukla, G., and Saltzman, B. (Eds.), Milankovitch and Climate (Pt. 1): Dordrecht, The Netherlands (D. Reidel), 269305.

Jackson, E. D., Bargar, K. E., Fabbi, B. P., and Heropoulos, C., 1976. Petrology of the basaltic rocks drilled on Leg 33 of the Deep Sea Drilling Project. In Schlanger, S. O., Jackson, E. D., et al., Init. Repts. DSDP, 33: Washington (U.S. Govt. Printing Office), 571630.

Janecek, T. R., 1985. Eolian sedimentation in the Northwest Pacific Ocean: a preliminary examination of the data from Deep Sea Drilling Project Sites 576 and 578. In Heath, G. R., Burckle, L. H., et al., Init. Repts. DSDP, 86: Washington (U.S. Govt. Printing Office), 589-603. 
Janecek, T. R., and Rea, D. K., 1983. Eolian deposition in the northeast Pacific Ocean: Cenozoic history of atmospheric circulation. Geol. Soc. Am. Bull., 94:730-738.

Johnson, T. C., Hamilton, E. L., and Berger, W. H., 1977. Physical properties of calcareous ooze: control by dissolution at depth. Mar. Geol., 24:259-277.

Karlin, R., and Levi, S., 1985. Geochemical and sedimentological control of the magnetic properties of hemipelagic sediments. J. Geophys. Res., 90:10,373-10,392.

Keigwin, L. D., 1978. Pliocene closing of the Isthmus of Panama, based on biostratigraphic evidence from nearby Pacific and Caribbean Sea cores. Geology, 6:630-634.

Keller, G., and Barron, J. A., 1987. Paleodepth distribution of Neogene deep-sea hiatuses. Paleoceanography, 2:697-713.

Kennett, J. P., 1982. Marine Geology: Englewood Cliffs, NJ (Prentice Hall).

Kennett, J. P. (Ed.), 1985. The Miocene Ocean: Paleoceanography and Biogeography. Mem. Geol. Soc. Am., No. 163.

Kennett, J. P., McBirney, A. R., and Thunell, R. C., 1977. Episodes of Cenozoic volcanism in the circum-Pacific region. J. Volcanol. Geotherm. Res., 2:145-163.

Kroenke, L., 1972. Geology of the Ontong Java Plateau. Hawaii Inst. Geophys Rep., HIG 72-5.

1974. Origin of continents through development and coalescence of oceanic flood basalt plateaus. Eos, 55:443.

1984. Cenozoic tectonic development of the southwest $\mathrm{Pa}$ cific. U. N. ESCAP, CCOP/SOPAC, Tech. Bull., No. 6.

Kroenke, L. W., Jouannic, C., and Woodward, P. (Comps.), 1983. Bathymetry of the Southwest Pacific: Chart 1 of the Geophysical Atlas of the Southwest Pacific, CCOP/SOPAC.

Leinen, M., 1979. Biogenic silica accumulation in the central equatorial Pacific and its implications for Cenozoic paleoceanography. Geol. Soc. Am. Bull., 90(Pt. 2):1310-1376.

Mahoney, J. J., 1987. An isotopic survey of Pacific oceanic plateaus: implications for their nature and origin. In Keating, B. H., Fryer, P., Batiza, R., and Boehlert, G. W. (Eds.), Seamounts, Islands, and Atolls. Am. Geophys. Union Monogr., 43:207-220.

Mammerickx, J., and Smith, S. M., 1985. Bathymetry of the North Central Pacific: Boulder, CO (Geological Society of America), Map and Chart Ser., No. MC-52.

Martin, J. H., Gordon, R. M., and Fitzwater, S. E., 1990. Iron in Antarctic waters. Nature, 345:156-158.

Mayer, L. A., Shipley, T. H., Theyer, F., Wilkens, R. W., and Winterer, E. L., 1985. Seismic modeling and paleoceanography at Deep Sea Drilling Project Site 574. In Mayer, L. A., Theyer, F., Thomas, E., et al., Init. Repts. DSDP, 85: Washington (U.S. Govt. Printing Office), 947-970.

Mayer, L. A., Shipley, T. H., and Winterer, E. L., 1986. Equatorial Pacific seismic reflectors as indicators of global oceanographic events. Science, 233:761-764.

McLean, D. M., 1985. Mantle degassing induced dead ocean in the Cretaceous-Tertiary transition. In Sundquist, E. T., and Broecker, W. S. (Eds.), The Carbon Cycle and Atmospheric $\mathrm{CO}_{2}$ : Natural Variations Archean to Present. Am. Geophys. Union Monogr., 32:493-503.

Miller, K. G., and Fairbanks, R. G., 1985. Oligocene to Miocene carbon isotope cycles and abyssal circulation changes. In Sundquist, E. J., and Broecker, W. S. (Eds.), The Carbon Cycle and Atmospheric $\mathrm{CO}_{2}$ : Natural Variations Archean to Present. Am. Geophys. Union Monogr., 32:469-486.

Monechi, S., 1985. Campanian to Pleistocene calcareous nannofossil stratigraphy from the northwest Pascific Ocean, Deep Sea Drilling Project Leg 86. In Heath, G. R., Burckle, L. H., et al., Init. Repts. $D S D P, 86$ : Washington (U.S. Govt. Printing Office), 301-336.

Moore, T. C., Pisias, N. G., and Heath, G. R., 1977. Climate changes and lags in Pacific carbonate preservation, sea surface temperature and global ice volume. In Malahoff, A., and Anderson, N. (Eds.), The Fate of Fossil Fuel $\mathrm{CO}_{2}$ in the Oceans: New York (Plenum Press), $145-165$.

Petit, J. R., Mounier, L., Jouzel, J., Korotkevich, Y. S., Kotlyakov, V. I., and Lorius, C., 1990. Paleoclimatological and chronological implications of the Vostok core dust record. Nature, 343:56-58.

Romine, K., and Lombari, G., 1985. Evolution of Pacific circulation in the Miocene: radiolarian evidence from DSDP Site 289. In Kennett, J. P. (Ed.), The Miocene Ocean: Paleoceanography and Biogeography. Mem. Geol. Soc. Am., 163:273-290.
Sager, W. W., 1987. Late Eocene and Maastrichtian paleomagnetic poles for the Pacific plate: implications for the validity of seamount paleomagnetic data. Tectonophysics, 144:301-314.

Saito, T., Burckle, L. H., and Hays, J. D., 1975. Late Miocene to Pleistocene biostratigraphy of equatorial Pacific sediments. In Saito, T., and Burckle, L. H. (Eds.), Late Neogene Epoch Boundaries. Spec. Publ., Micropaleontol., 1:226-244.

Schlanger, S. O., and Douglas, R. G., 1974. The pelagic ooze-chalklimestone transition and its implication for marine stratigraphy. In Hsü, K. J., and Jenkyns, H. C. (Eds.), Pelagic Sediments: On Land and Under the Sea. Spec. Publ., Int. Assoc. Sedimentol., 1:117148.

Shackleton, N. J., Backman, J., Zimmerman, H., Kent, D. V., Hall, M. A., Roberts, D. G., Schnitker, D., Baldauf, J., Desprairies, A., Homrighausen, R., Huddlestun, P., Keene, J. B., Kaltenback, A. J., Krumsiek, K.A.O., Morton, A. C., Murray, J. W., and WestbergSmith, J., 1984. Oxygen isotope calibration of the onset of ice-rafting in DSDP Site 552A: history of glaciation in the North Atlantic region. Nature, 307:620-623.

Shackleton, N. J., and Kennett, J. P., 1974. Paleotemperature history of the Cenozoic and the initiation of Antarctic glaciation: oxygen and carbon isotope analyses in DSDP Sites 277, 279 and 281. In Kennett, J. P., Houtz, R. E., et al., Init. Repts. DSDP, 29: Washington (U.S. Govt. Printing Office), 743-755.

Shipboard Scientific Party, 1971. Site 64. In Winterer, E. L., Riedel, W. R., et al., Init. Repts. DSDP, 7: Washington (U.S. Govt. Printing Office), 473-606.

1975a. Site 288. In Andrews, J. E., Packham, G., et al., Init. Repts. DSDP, 30: Washington (U.S. Govt. Printing Office), 175229.

1975b. Site 289. In Andrews, J. E., Packham, G., et al., Init. Repts. DSDP, 30: Washington (U.S. Govt. Printing Office), 231398.

1986. Site 586. In Moberly, R., Schlanger, S. O., et al., Init. Repts. DSDP, 89: Washington (U.S. Govt. Printing Office), 213281.

Stoeser, D. B., 1975. Igneous rocks from Leg 30 of the Deep Sea Drilling Project. In Andrews, J. E., Packham, G., et al., Init. Repts. DSDP, 30: Washington (U.S. Govt. Printing Office), 401-414.

Storey, M., Mahoney, J. J., Kroenke, L. W., and Saunders, A. D., in press. Are oceanic plateaus sites of komatiite formation? Geology.

Theyer, F., Vincent, E., and Mayer, L. A., 1989. Sedimentation and paleoceanography of the central equatorial Pacific. In Winterer, E. L., Hussong, D. M., and Decker, R. W. (Eds.), The Geology of North America (Vol. N): The Eastern Pacific Ocean and Hawaii: Boulder, CO (Geological Society of America), 347-372.

Thierstein, H. R., 1979. Paleoceanographic implications of organic carbon and carbonate distribution in Mesozoic deep sea sediments. In Talwani, M., Hay, W., and Ryan, W.B.F. (Eds.), Deep Drilling Results in the Atlantic Ocean: Am. Geophys. Union, Maurice Ewing Ser., 3:249-274.

Vail, P. R., and Hardenbol, J., 1979. Sea-level changes during the Tertiary. Oceanus, 22:71-79.

van Andel, T. H., Heath, G. R., and Moore, T. C., Jr., 1975. Cenozoic history and paleoceanography of the central equatorial Pacific. Mem. Geol. Soc. Am., 143:1-134.

van Houten, F. B., 1982. Ancient soils and ancient climates. In Berger, W. H., and Crowell, J. C. (Eds.), Climate in Earth History: Washington (National Academy Press), 112-117.

Vincent, E., and Berger, W. H., 1985. Carbon dioxide and polar cooling in the Miocene: the Monterey Hypothesis. In Sundquist, E., and Broecker, W. S. (Eds.), The Carbon Cycle and Atmospheric $\mathrm{CO}_{2}$ : Natural Variations Archean to Present: Am. Geophys. Union Monogr., 32:455-468.

Whitman, J., and Berger, W. H., in press. Pliocene-Pleistocene oxygen isotope record, Site 586, Ontong Java Plateau. Mar. Micropaleontol.

Woodruff, F., Savin, S. M., and Douglas, R. G., 1981. Miocene stable isotope record: a detailed deep Pacific Ocean study and its paleoclimatic implications. Science, 212:665-668.

Wu, G., and Berger, W. H., in press. Pleistocene $\delta^{18} \mathrm{O}$ records from Ontong Java Plateau: effects of winnowing and dissolution. Mar. Geol.

Ms 130A-110 